\title{
Nepal: 2005 Article IV Consultation-Staff Report; Public Information Notice on the Executive Board Discussion; and Statement by the Executive Director for Nepal
}

Under Article IV of the IMF's Articles of Agreement, the IMF holds bilateral discussions with members, usually every year. In the context of the 2005 Article IV consultation with Nepal, the following documents have been released and are included in this package:

- the staff report for the 2005 Article IV consultation, prepared by a staff team of the IMF, following discussions that ended on November 2, 2005, with the officials of Nepal on economic developments and policies. Based on information available at the time of these discussions, the staff report was completed on December 30, 2005. The views expressed in the staff report are those of the staff team and do not necessarily reflect the views of the Executive Board of the IMF.

- a Public Information Notice (PIN) summarizing the views of the Executive Board as expressed during its January 18, 2006 discussion of the staff report that concluded the Article IV consultation.

- $\quad$ a statement by the Executive Director for Nepal.

The document listed below has been or will be separately released.

Selected Issues Paper and Statistical Appendix

The policy of publication of staff reports and other documents allows for the deletion of market-sensitive information.

To assist the IMF in evaluating the publication policy, reader comments are invited and may be sent by e-mail to publicationpolicy@imf.org.

\author{
Copies of this report are available to the public from \\ International Monetary Fund • Publication Services \\ $70019^{\text {th }}$ Street, N.W. • Washington, D.C. 20431 \\ Telephone: (202) 623-7430 • Telefax: (202) 623-7201 \\ E-mail: publications@imf.org • Internet: http://www.imf.org
}

Price: $\$ 15.00$ a copy

\section{International Monetary Fund Washington, D.C.}





\title{
INTERNATIONAL MONETARY FUND
}

\author{
NEPAL \\ Staff Report for the 2005 Article IV Consultation \\ Prepared by Staff Representatives for the 2005 Consultation with Nepal \\ Approved by Wanda Tseng and Matthew Fisher
}

December 30, 2005

- A staff team visited Kathmandu during October 20-November 2, 2005 to conduct the 2005 Article IV consultation discussions. The team comprised Sanjay Kalra (head), Ari Aisen, Nombulelo Wandwasi (all APD), Christian Beddies (PDR), and Sukhwinder Singh (Resident Representative). The mission met former Finance Minister Rana, State Finance Minister Jyoti, National Planning Commission Vice Chairman Sharma, Nepal Rastra Bank Governor Bhattarai, Chief Cabinet Secretary Karki, Finance Secretary Acharya, and other senior officials. The mission also met representatives of the donor community, private sector, labor unions, political parties and civil society, and journalists. The mission coordinated closely with resident missions of the World Bank and Asian Development Bank, and bilateral donors. Ms. Phang (Executive Director) and Mr. Sukada (Alternate Executive Director) participated in the consultation discussions.

- Nepal accepted the obligations of Article VIII, Sections 2, 3, and 4 in May 1994, and the exchange system is free of restrictions on the making of payments and transfers for current international transactions.

- The 2003 Article IV consultation was concluded by the Executive Board on August 22, 2003. Executive Directors emphasized the need to alleviate poverty by raising economic growth over the medium term through the implementation of structural reforms, especially in the financial and public sectors. Directors commended the authorities for maintaining broad fiscal stability to create conditions to support economic growth. Directors also agreed that monetary and exchange rate policies should remain geared to supporting the exchange rate peg. They also underlined that growth prospects remain contingent on political stability, improved security, and progress towards peace.

- The principal authors of this staff report are Sanjay Kalra and Sukhwinder Singh. 


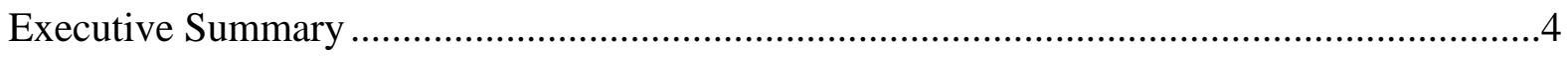

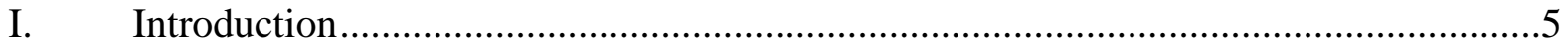

II. Stocktaking and Recent Developments ........................................................

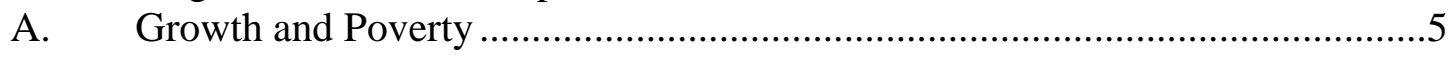

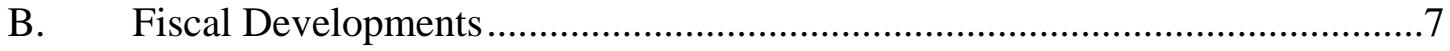

C. Monetary and External Sector Developments ...........................................

III. Outlook and Risks................................................................................... 10

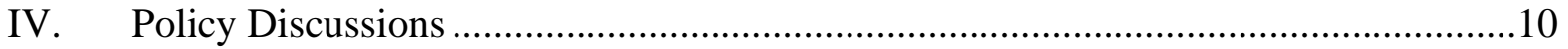

A. Maintaining Macroeconomic Stability ...................................................... 11

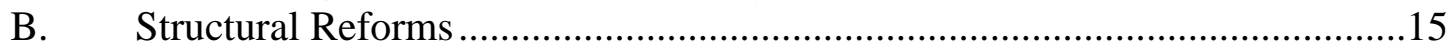

C. PRGF Arrangement ...............................................................................19

D. Enhanced HIPC and Multilateral Debt Relief Initiatives ............................19

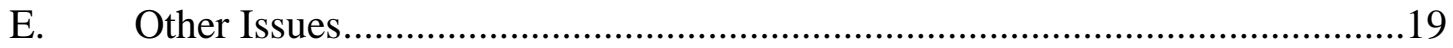

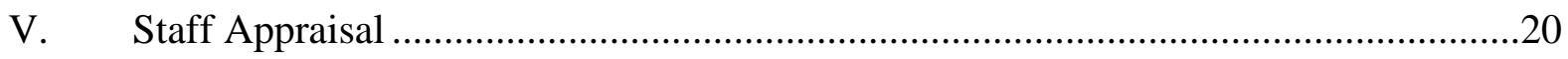

Boxes

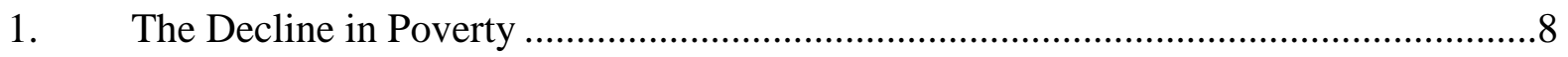

2. Land Reforms and Agricultural Productivity .................................................. 18

Figure

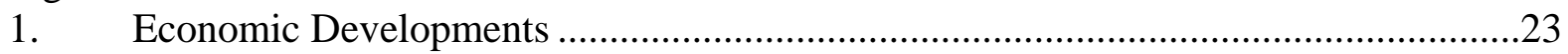

Tables

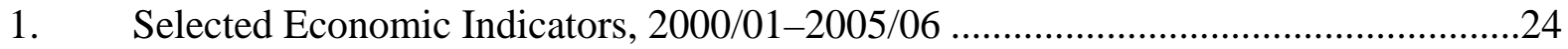

2. Summary of Government Operations, 2003/04-2007/08 .......................................25

3. Monetary Accounts, 2002/03-2005/06.................................................................26

4. Balance of Payments, 2000/01-2009/10...........................................................27

5. Medium-Term Macroeconomic Framework, 2001/02-2009/10 ..............................28

6. Status of Quantitative Performance Criteria and Indicative Targets ..........................29

7. Status of Structural Performance Criteria and Benchmarks for Second Review

Under the PRGF Arrangement.......................................................................... 30

8. Structural Performance Criteria and Benchmarks for the Third Review

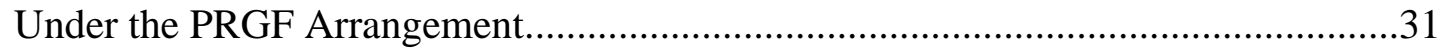

9. Millennium Development Goals, 1990-2015 ....................................................32 


\section{Annexes}

1. Past Main Policy Recommendations and the Authorities' Responses ......................33

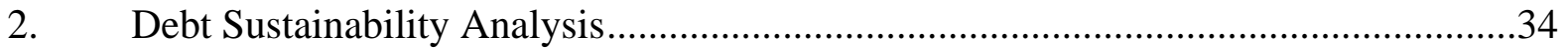

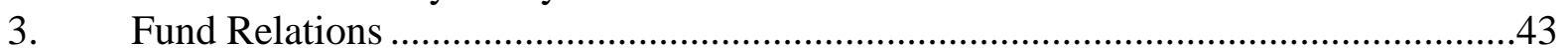

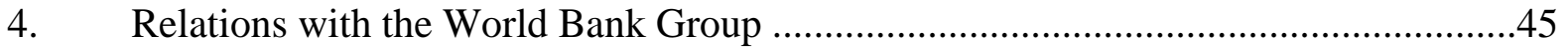

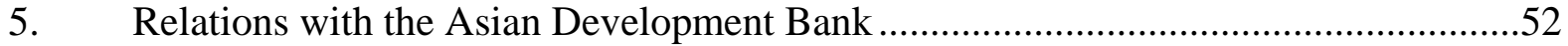

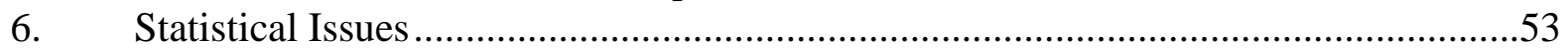




\section{Executive Summary}

Continued political tensions and the decade long insurgency continue to dampen growth and impede poverty reduction. Real GDP growth averaged 2 percent during 2000/01-2004/05, compared to 5 percent in the 1990s. Notwithstanding a decline during the last decade, poverty remains high. Nepal also lags in human development indicators. The proximate causes are insufficient growth, inefficient resource allocation in key sectors, and poor governance and social service delivery. While macroeconomic stability has been maintained, institution building and structural reform implementation has lagged.

Growth is projected to remain modest and risks remain. GDP growth is expected to be $2 \frac{1}{2}-3 \frac{1}{2}$ percent in $2005 / 06$ and is projected to rise to $5-51 / 2$ percent over the medium term, if the security situation improves, political tensions can be resolved, and structural reforms are implemented. While manufacturing and tourism are expected to be the main sources of growth, a significant contribution from agriculture is also envisaged. Inflation is expected to remain below 5 percent. The current account deficit is projected to increase, but higher aid, remittances, and other inflows should allow international reserves to be maintained at adequate levels. The security situation, political tensions, and shortfall in external aid if structural reform implementation does not proceed remain key risks.

Key fiscal policy challenges over the medium term are to improve revenue mobilization, prioritize spending, and contain domestic borrowing. While the revenue-to-GDP ratio has risen, in part due to an increase in the VAT rate, measures to strengthen administration are required by improving the operations of the Large Taxpayer Office and customs administration, and plugging excise leakages. Despite security-related spending pressures, which remain high, spending needs to be directed toward priority social and infrastructure sectors to help reduce poverty. Limited domestic borrowing and efforts to mobilize external aid will help maintain fiscal sustainability.

Monetary policy should remain geared to supporting the peg to the Indian rupee. The peg has served Nepal well given close ties with India and has helped to keep inflation at low levels. The level of the peg appears broadly appropriate for now, but should remain under review, given impending commitments under global and regional trading arrangements and external shocks. Competitiveness needs to be raised through labor market reforms, improvement in the business climate, and better infrastructure to lower transactions and transportation costs.

Structural reform implementation is critical to restoring growth and reducing poverty. The key reform areas are financial sector, public enterprises, and governance. In the financial sector, the critical issue is to increase significantly loan recoveries from large, willful defaulters. Other priorities include improving financial sector legislation, strengthening the central bank, and restructuring insolvent commercial and development banks to improve intermediation. Liquidation of unviable pubic enterprises should proceed quickly. Governance reforms are required to increase accountability and reduce corruption. 


\section{INTRODUCTION}

1. This Article IV consultation takes place against a background of continued political tensions in Nepal. Tensions have intensified since King Gyanendra took over executive powers on February 1, 2005. While King Gyanendra has promised to restore democracy and security within three years, key political parties and civil society are engaged in street protests for immediate and full restoration of multiparty democracy. These protests have the potential - as they did in the early 1990s - to take a violent turn. Although municipal elections have been announced for February 2006 and parliamentary elections by April 2007, there is widespread skepticism as to whether the elections can be conducted in a free and fair manner, given the ongoing insurgency and security situation.

\section{The royal takeover and subsequent government actions have also met with} international criticism. Key countries have placed their military and bilateral assistance under review. Restrictions on the media and on activities of NGOs have also drawn international criticism. Donors have called-with no perceptible impact-for all sides to negotiate a peaceful settlement to address the root causes of the insurgency.

3. The insurgency—now a decade old—reflects widespread poverty, exclusion, and poor governance and continues to take a heavy human toll. Casualties from the insurgency now exceed 12,000 and most observers rule out a military solution. Meanwhile, the unilateral ceasefire by the insurgents which has been in place since September and a joint statement by the key political parties and insurgents in November are raising pressures on King Gyanendra to negotiate a settlement.

\section{StOCKTAKING AND RECENT DEVELOPMENTS}

\section{A. Growth and Poverty}

4. The key economic policy challenge facing Nepal is to raise growth and reduce poverty. A series of governments helped finalize a poverty reduction strategy in May 2003, after extensive consultations with stakeholders and donors. The Poverty Reduction Strategy Paper (PRSP) is based on four pillars: broad-based economic growth; social sector development; targeted programs for the poor and deprived groups; and good governance. ${ }^{1}$ PRSP objectives include macroeconomic stability, institution building, and structural reforms to raise growth. Even as the current government has placed greater emphasis on security than previous governments, the PRSP continues to broadly guide its economic policies.

\footnotetext{
${ }^{1}$ A Joint Staff Assessment of the PRSP was circulated to Executive Boards of the IMF and the World Bank in October 2003. A Joint Staff Advisory Note on progress in implementing PRSP policies during 2003/04 was circulated to the Boards in December 2005.
} 
5. Notwithstanding a broad consensus on PRSP strategy, political uncertainties have impeded implementation since mid-2004. Prior to mid-2004, structural reforms progressed, including in the context of the PRGF arrangement, World Bank, AsDB, and other donor supported programs. ${ }^{2}$ A number of policy recommendations made during the 2003 Article IV consultation have been implemented (Annex I). The takeover by King Gyanendra appears to have pushed reforms to the backburner as the government has tried to address the security situation and political opposition to the takeover.

6. Growth has fallen significantly below the trend rate of the 1990s since the intensification of the insurgency in 2000. Real GDP growth averaged 2 percent during 2000/01-2004/05, compared to the 1990s when significant trade liberalization contributed to average real GDP growth of 5 percent. ${ }^{34}$ Since the intensification of the insurgency, manufacturing and transportation have suffered from destruction of production capacity, work stoppages, and extortion by insurgents. Tourist arrivals remain below peak levels of the late 1990s. Progress in implementing large infrastructure and

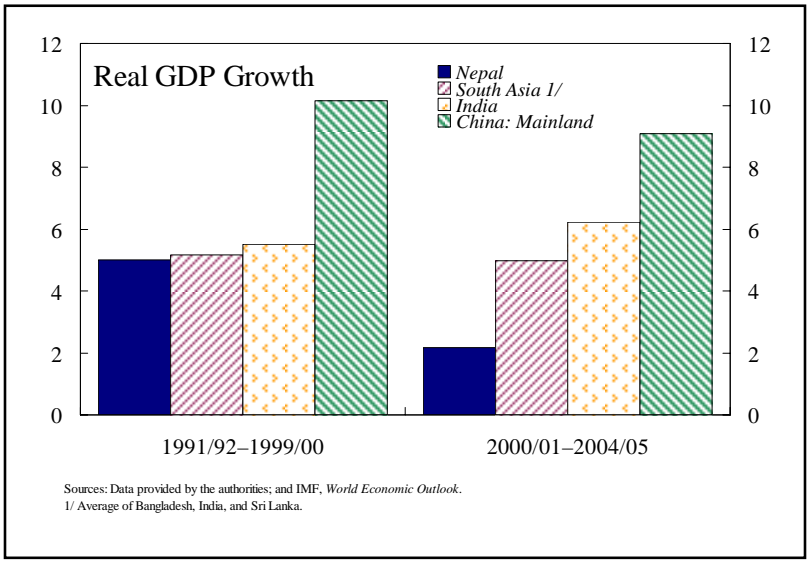
hydroelectric projects has also been impeded by security concerns.

7. Growth fell to $2 \frac{1}{2}$ percent in $\mathbf{2 0 0 4 / 0 5}$, and inflation has risen in recent months. Growth was lower both in the agricultural and nonagricultural sectors compared to 2003/04. Inflation has remained in the low single digits, although it rose to $73 / 4$ percent in mid-October 2005 (12-month basis), including on account of the VAT rate increase in January 2005 and partial pass-through of higher international oil prices by Nepal Oil Corporation (NOC).

8. Notwithstanding a decline in the last decade, poverty remains high and human development indicators are low. The poverty ratio fell from 42 percent in 1995/96 to

${ }^{2}$ A Poverty Reduction Support Credit was approved by the World Bank in 2003. AsDB has provided support through Governance Reform Program and Public Sector Management Loan.

${ }^{3}$ Fiscal year begins mid-July.

${ }^{4}$ Staff's analysis suggests that, compared to other South Asian countries, more frequent shifts in government in Nepal reduced growth by an estimated 3/4 percent per year. Chapter I, selected issues paper, "Political Instability and Growth in Nepal." 
31 percent in 2003/04, including on account of rising remittances which were a mainstay of the economy in a difficult period (Box 1$).^{5}$ The decline in poverty was broad based.

Nevertheless, poverty in certain regions and the population living on less than $\$ 1 /$ day is high and human development indicators are low relative to Nepal's MDG targets.

\begin{tabular}{|c|c|c|c|c|c|c|c|}
\hline \multicolumn{8}{|c|}{ Selected Social Indicators in Asia, 2003} \\
\hline & Nepal & China & Sri Lanka & India & Bangladesh & Bhutan & Pakistan \\
\hline Human development index rank & 136 & 85 & 93 & 127 & 139 & 134 & 135 \\
\hline Life expectency at birth & 62 & 72 & 74 & 63 & 63 & 63 & 63 \\
\hline Adult literacy rate & 49 & 91 & 90 & 61 & 41 & 47 & 49 \\
\hline \multicolumn{8}{|l|}{ Reduction in infant mortality } \\
\hline (from 1970; per 1,000 live births & 104 & 55 & 52 & 64 & 99 & 86 & 39 \\
\hline Infant mortality (per 1,000 live births) & 61 & 30 & 13 & 63 & 46 & 70 & 61 \\
\hline Population on less than $\$ 1 /$ day (in percent) $1 /$ & 24.1 & 16.6 & 7.6 & 35.3 & 36.0 & $\ldots$ & $\ldots$ \\
\hline
\end{tabular}

\section{B. Fiscal Developments}

9. In recent years, an increase in revenue mobilization has offset the decline in external aid to help maintain expenditure and limit domestically financed deficits.

Compared to the 1990s, domestic revenue collection rose by over 2 percent of GDP during 2000/01-2004/05. ${ }^{6}$ This increase helped sustain an increase in securityrelated and social services spending (education, health, drinking water, and local development), while also limiting overall and domestically financed deficits even as external aid flows declined.

\section{The overall and domestically} financed deficits remained limited in 2004/05. The VAT rate was raised in the revised budget from 10 percent to 13 percent in early-2005, and helped

\begin{tabular}{lcc}
\multicolumn{3}{c}{ Nepal: Government Operations } \\
\hline & 1990/91-1999/00 & 2000/01-2004/05 \\
\hline & (Annual average, percent of GDP) \\
Revenue and grants & 11.4 & 14.0 \\
Of which: revenue & 9.7 & 12.1 \\
Expenditure and net lending & 16.2 & 16.4 \\
Of which: current & $\ldots$ & 11.4 \\
Deficit (after grants) & 4.8 & 2.5 \\
Foreign financed & 3.1 & 1.0 \\
Domestically financed & 1.7 & 1.5 \\
Memorandum item: & & \\
Social services 1/ & 4.5 & 5.3 \\
Of which: health and education & 3.0 & 3.8 \\
Security related & 1.8 & 2.9 \\
External aid & 4.8 & 2.9 \\
\hline
\end{tabular}

Sources: IMF, GFS; IMF, IFS; FCGO, Economic Survey; and staff estimates.

1/ Social services include education, health, drinking water, and local development. raise revenue by $3 / 4$ percentage point of GDP to 13 percent of GDP (Table 2). Even so, revenue fell short of the revised budget target due to weaker than projected growth and

\footnotetext{
${ }^{5}$ Chapter II, selected issues paper, "Remittances and the Nepalese Economy."

${ }^{6}$ The VAT was introduced in 1997, and the 2002 income tax reforms closed a number of loopholes and broadened the tax base.
} 


\section{Box 1. Nepal: The Decline in Poverty}

Poverty in Nepal fell dramatically between 1995/96 and 2003/04. ${ }^{1}$ During this period, the poverty headcount is estimated to have fallen from 42 percent to 31 percent. Poverty declined in both rural and urban areas, and across regions. Inequality also increased. This increase was largely due to faster growth of consumption in the highest income group.

This decline in poverty is attributable to solid growth in remittances and wages, improved connectivity,

\begin{tabular}{|c|c|c|c|c|c|}
\hline \multicolumn{6}{|c|}{ Nepal: Growth and Redistribution Components of Decline in Poverty } \\
\hline & \multirow[b]{2}{*}{$1995 / 96$} & \multirow[b]{2}{*}{$2003 / 04$} & \multirow[b]{2}{*}{ Change } & \multicolumn{2}{|c|}{ Contribution } \\
\hline & & & & Growth & Inequality \\
\hline & \multicolumn{2}{|c|}{ (In percent) } & \multicolumn{3}{|c|}{ (In percentage points) } \\
\hline Nepal & 42 & 31 & -11 & -24 & 13 \\
\hline Urban & 22 & 10 & -12 & -12 & 0 \\
\hline Rural & 43 & 35 & -9 & -17 & 9 \\
\hline
\end{tabular}

Source: The World Bank, Nepal: Draft Poverty Assessment, December 2005.

urbanization, and a decline in the dependency ratio. With an estimated 1 million workers abroad in 2004, remittances to 12 percent of GDP, contributing to an increase in real per capita expenditure by 42 percent. Agricultural wages increased by about 25 percent in real terms over the period due to tighter labor market conditions and better connectivity through rural roads. The ratio of the population in urban areas-where poverty was lower to start with-rose from 7 percent to 15 percent. The larger decline in urban poverty reflects higher education levels, higher economic returns to skills, and wider opportunities for gainful employment in these areas. Increased urbanization shifted the labor force to higher productivity jobs in the urban centers.

A cross-section analysis of the 2003/04 data points to the correlates of poverty. The following factors are associated with a lower probability of a household being poor: higher levels of schooling of the head of the household; the household head's main occupation is in trade and services; the household is female headed; households with more land; and households with a smaller number of children less than 6 years old.

This analysis of poverty points to a number of policy conclusions. It highlights that poverty alleviation requires sustained growth, improved developmental impact of remittances, better physical and social infrastructure, human capital, and asset ownership. At the same time, it suggest that the positive effects of growth on poverty reduction-most importantly through a restoration of peace and stability - can be complemented by continued decentralization and measures to combat social exclusion.

${ }^{1}$ Nepal Living Standards Survey, The World Bank, 2005. 
imports, continued excise leakages, and delayed excise duty refunds from India. Current spending was lower than the revised budget: the higher civil service wages and allowances and security-related expenditures were more than offset by lower spending on development and social sector projects, especially in the conflict-affected areas. The overall deficit was lower than budgeted (1 percent of GDP compared to $2 \frac{1}{2}$ percent of GDP). As a result, although external loans fell short of the budget, as assistance from the World Bank, AsDB, and donors dwindled, the domestically financed deficit was also lower than budgeted (at $1 / 2$ percent of GDP).

\section{Monetary and External Sector Developments}

\section{Monetary and exchange rate policies remained geared to supporting the}

exchange rate peg to the Indian rupee. Broad money growth slowed from $123 / 4$ percent in 2003/04 to 8 percent in 2004/05, reflecting substantially lower NFA accumulation by the NRB (Table 3). While budget financing from the banking system was limited, private sector credit grew by 131/4 percent, mainly in consumer lending. Balance sheet consolidation by the two largest banks undergoing restructuring limited the growth of loans for manufacturing and services sectors. With high remittances, liquidity was ample, T-bill rates remained low, and interest rates edged lower.

\section{The current account and} overall balance of payments remained in surplus. Despite disruptions related to the insurgency and the elimination of textile quotas, total exports rose by 10 percent in 2004/05. This was mainly due to booming exports to India which rose by 30 percent, while exports to other countries declined by over 15 percent (Table 4). Export performance in traditional sectors-garments, carpets, and pashmina-remained weak. ${ }^{7}$ Total import growth was stagnant due to weak economic activity - a 35 percent increase in oil imports reflecting higher

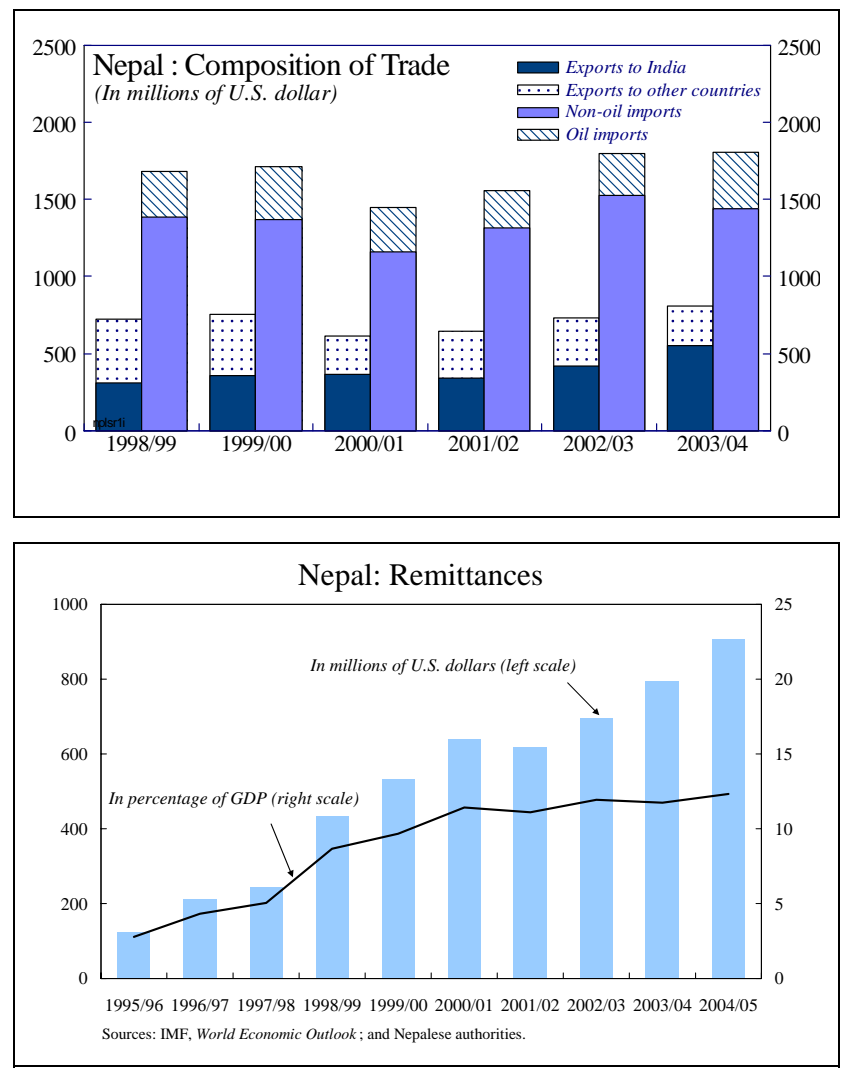

${ }^{7}$ In particular, garment exports fell by 37 percent (after a 20 percent decline in 2003/04). While the removal of MFA quotas contributed to this decline, domestic inefficiencies and disruptions were also significant contributory factors. 
international prices was offset by a 6 percent decline in non-oil imports. Reflecting continued strong remittances, the current account surplus (excluding official transfers) increased from 1 percent of GDP in 2003/04 to 3 percent of GDP in 2004/05. A small overall surplus in the balance payments led to an increase in international reserves to around US $\$ 11 / 2$ billion at end-2004/05 (71/2 months of imports of goods and services).

\section{OUTLOOK AND RISKS}

\section{Nepal's growth prospects are contingent on political stability and improved} security. Staff project real GDP growth of $2 \frac{1 / 2-31 / 2}{2}$ percent in 2005/06. With the peg, inflation is expected to broadly follow price developments in India, although a full pass-through of international oil prices could temporarily add 2-3 percentage points to inflation in 2005/06. In this scenario, if political stability and better security conditions can be established and structural reforms are implemented, Nepal could see a gradual return to growth rates of 5-51/2 percent through 2009/10. This would require a rebound in manufacturing and service sectors, higher tourism earnings, and a larger contribution from agriculture and government activity. The external position would be supported by export diversification, tourism, remittances, and aid flows. However, if the conflict persists and the political impasse stalls reform implementation, low growth rates are likely to become entrenched, security-related spending pressures will remain high, and development spending low. In these conditions, the fiscal and external position could deteriorate, and international reserves could be lower.

\section{Policy Discussions}

14. The consultation discussions focused on two main issues. First, how to preserve macroeconomic stability by implementing a fiscal framework focused on mobilizing revenue, containing expenditure, and limiting domestic financing to levels consistent with medium-term fiscal sustainability and gearing monetary and exchange rate policies to support the exchange rate peg to the Indian rupee. Second, how to further reform implementation under the current political conditions to improve growth prospects and reduce poverty. It was agreed that the PRSP strategy remains broadly appropriate. It was also agreed that further reforms in the financial sector, public enterprises and governance, and regulation and labor market would help to address fundamental constraints on growthinadequate financial intermediation, inefficient resource allocation in the public and private sectors, a deficient climate for business activity, and rigidities in the labor market. Reforms are also required in agriculture, the largest sector in the economy, to achieve productivity increases which can raise farm incomes and ensure that land reforms are more successful in their objective of reducing poverty. On implementation, the authorities acknowledged that reforms had been slowed by political considerations but pointed to measures taken since mid-2005, especially the promulgation of five key ordinances to improve governance and the regulatory framework, as demonstration of their resolve to implement PRSP reforms. 


\section{A. Maintaining Macroeconomic Stability}

\section{Fiscal Policies}

\section{The 2005/06 budget was formulated in line with medium-term fiscal objectives} of improving revenue mobilization, containing expenditure pressures, and limiting domestically financed deficits. Revenue was projected to increase through the full year effect of the higher VAT rate, steps to plug excise leakages, and a step-up in privatization. The budget also made allocations for a significant step-up in development spending, including in the conflict-affected areas, and assumed that support from the World Bank would be available through a follow-up PRSC. The budget targeted an overall deficit of 2 percent of GDP and domestic financing of $3 / 4$ percent of GDP.

16. While revenue and external aid are projected to be lower than the budget, lower expenditure would help limit domestic financing in 2005/06. The authorities agreed with staff that lower growth and the unsettled security conditions would likely lead to revenue shortfalls. However, they were optimistic, more so than staff, that improvements in tax administration - the October Finance Ordinance and introduction of the security sticker regime for excisable goods — could offset some of revenue decline from lower growth. ${ }^{8}$ There was also agreement that social sector grants and foreign-financed capital expenditures would remain low due to difficulties in carrying out development activities in conflictaffected areas. Staff encouraged the authorities to further pursue higher social sector and infrastructure spending (especially for rural roads) through greater community and user group participation. The overall deficit is projected to be lower than budgeted (at 11/4 percent of GDP). While external loans would likely be lower than budgeted, the authorities believed that domestic financing could be contained to $3 / 4$ percent of GDP; staff estimated that it could be around 1 percent of GDP.

17. To alleviate donor concerns about the quality of spending, staff urged the authorities to improve fiscal transparency and public expenditure management. Within limits placed by national security considerations, the authorities agreed that reporting of security-related spending could be more comprehensive. They also intended to implement ROSC recommendations, including broader coverage of off-budget activities and integration of annual budgets into the Medium Term Expenditure Framework (MTEF). A strengthened MTEF could incorporate higher pro-poor allocations, improve unit costing, and enhance reporting of outcomes. Staff cautioned against nonconcessional external loans, government

\footnotetext{
${ }^{8}$ The main tax administration provisions of the Finance Ordinance relate to a voluntary disclosure of stocks and partial deferral of the tax liability (without penalty), greater public awareness to broaden VAT registration, and reintroduction of the VAT threshold for selected goods (such as electronics) where tax evasion is considered to be extensive. The sticker regime consists of affixing excise stamps to individual items to reduce tax evasion.
} 
guarantees, and suppliers credits. These options were contemplated recently for some defense-related purchases.

18. For the medium term, the authorities aimed to further mobilize revenue and limit domestic financing while meeting higher expenditure needs. Improvements in administration, including lower excise leakages and elimination of VAT exemptions, would help boost revenue. The authorities were considering introduction of performance-based incentive schemes in the Large Taxpayer Office (LTO) and customs administration to improve collections, but noted implementation difficulties related to design of the schemes and resistance from other parts of the civil service. A further increase in the VAT rate could also be considered, if needed, to meet recurrent spending needs, along the lines recommended in past IMF technical assistance. On expenditure, the authorities noted that security-related spending can be expected to remain high, and characterized such spending as "an investment in peace." They also noted that spending needs to improve physical and human capital are high. In addition, the budget would have to shoulder the carrying cost of contingent liabilities from financial sector and public enterprise reforms. ${ }^{9}$ These carrying costs (interest on bonds and liquidation costs of public enterprises) would be around $1 / 4-3 / 4$ percent of GDP. Staff estimates suggest overall deficits would rise as development spending rises. However, with adequate external aid domestic financing could be limited to $3 / 4$ percent of GDP through 2010/11. Should aid fall short, spending on foreign-financed capital projects is likely to be commensurately lower.

19. While Nepal's public debt is projected to decline over the medium term, external debt vulnerabilities remain. Excluding contingent liabilities, public and publicly guaranteed (PPG) debt is projected to fall toward 50 percent of GDP by 2010/11. In an alternative scenario with lower growth, the debt-to-GDP ratio would still fall, but by a smaller amount. As regards external debt, most debt indicators remain below the policy-dependent indicative thresholds (based on World Bank classification of Nepal as a medium policy performer). However, at 172 percent, the NPV of debt-to-exports of goods and services ratio at end-2004/05 exceeded the

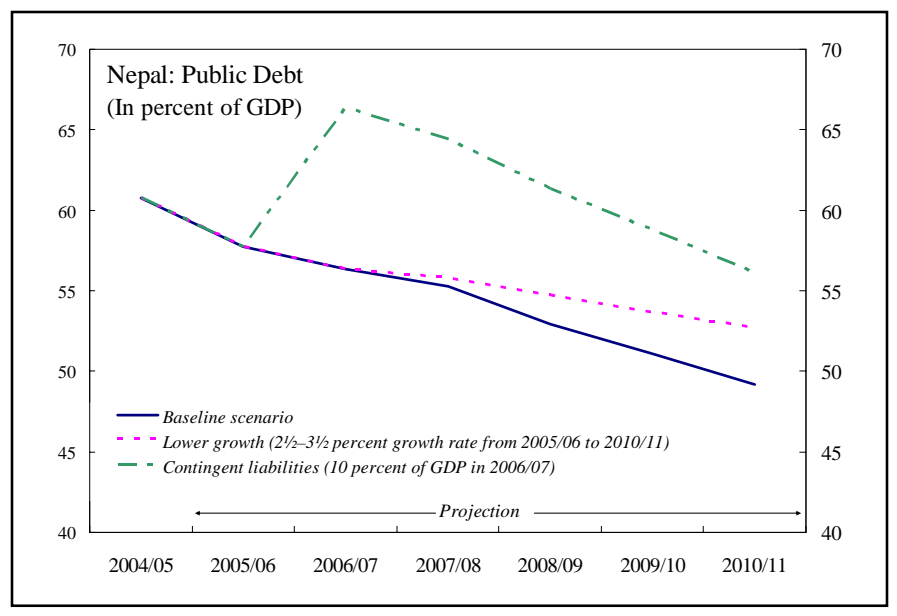

\footnotetext{
${ }^{9}$ These liabilities are currently estimated at 7-8 percent of GDP, the bulk of it for recapitalization of NBL and RBB (6-7 percent of GDP).
} 
indicative threshold of 150 percent. ${ }^{10}$ This reflected a low ratio of exports of goods and services to GDP (16 percent) even as the NPV of debt-to-GDP ratio was $273 / 4$ percent. Moreover, Nepal remains vulnerable to shocks, especially export growth slowdowns, and the sensitivity analysis indicates that external debt dynamics are subject to a high risk of distress (Annex II).

\section{Nepal Oil Corporation}

20. Notwithstanding past price hikes, the NOC has operating and accumulated losses due to inadequate pass-through of higher international oil prices. The NOC has raised prices of petroleum products by 25-65 percent since December 2003. However, prices for diesel and kerosene may have to be raised by an additional 25-30 percent to stem NOC losses. ${ }^{11}$ In September 2005, the budget provided a loan of Nrs 1 billion (1/4 percent of GDP) to service payables to Indian Oil Corporation (IOC). Meanwhile, commercial banks are increasingly unwilling to lend to NOC without government guarantees.

\section{The authorities recognized that an automatic pricing mechanism and full} pass-through of international prices to improve NOC finances was overdue. Given that higher international oil prices are likely to persist, the authorities considered a phased, full pass-through to domestic prices unavoidable and were considering raising prices by end-2005. Staff noted that World Bank estimates suggest that the impact of the price changes on the poor would be small, given consumption patterns reported in the 2003/04 Nepal Living Standards Survey. ${ }^{12}$ The authorities also plan to allow private participation in the

${ }^{10}$ These projections, conducted jointly with World Bank staff, are based on the Low-Income Country Debt Sustainability Analysis (LIC-DSA) framework. The NPV of external debt-toexports ratio was reported at 136 percent at the time of the first review under the PRGF arrangement (IMF Country Report No. 04/329). The higher value of 172 percent is attributable to higher reported debt service obligations compared to previous submissions. The current submission has been scrutinized for consistency with creditor records.

11 These losses are currently estimated at Nrs 450-550 million per month (1 percent of GDP on an annualized basis). In addition, the debt obligations of NOC are estimated at Nrs 6 billion (1 percent of GDP), including suppliers credits from IOC. The NOC breaks even on its petrol and aviation fuel operations. Implementation of an automatic pricing mechanism at prices reflecting NOC cost structure — scheduled for end-December 2004was a third review structural PC under the PRGF arrangement.

${ }^{12}$ Results from the World Bank's Poverty and Social Impact Analysis suggest that given the low share of expenditure on petroleum products (primarily kerosene) by the lowest quintiles of households in the urban areas, the impact of a price increase would be small. In the rural areas, the use of kerosene is more limited as the primary fuel for cooking is firewood. 
petroleum sector, leaving NOC only as a wholesaler. A review of NOC is also currently in progress to accurately assess its financial position and operating efficiency.

\section{Monetary and Exchange Rate Policy}

22. The staff supported Nepal Rastra Bank's view that the exchange rate peg to the Indian rupee continues to be appropriate. Private sector representatives have asked, on occasion, whether a more flexible exchange rate arrangement could help Nepal adjust better to external shocks. The staff shared the NRB's view that the peg has enabled the economy to benefit from its close economic ties with India. These ties include extensive trade links, free labor mobility through porous borders, and formal business links and informal family relations. In particular, the peg eliminates exchange rate risk in the large volume of current and capital account transactions with India. The peg provides credibility to policy by importing stable monetary conditions from India and has contributed to low inflation rates. The peg has also contributed to maintaining fiscal discipline, especially in the current environment where spending pressure are high.

\section{The NRB broadly agreed} with the staff's assessment that the level of the peg appears to allow sufficient competitiveness. In particular, overall exports have grown in recent years even as the real effective exchange rate (REER, CPI-based) appears to have remained broadly stable. It was agreed that external sector developments such as elimination of MFA quotas in

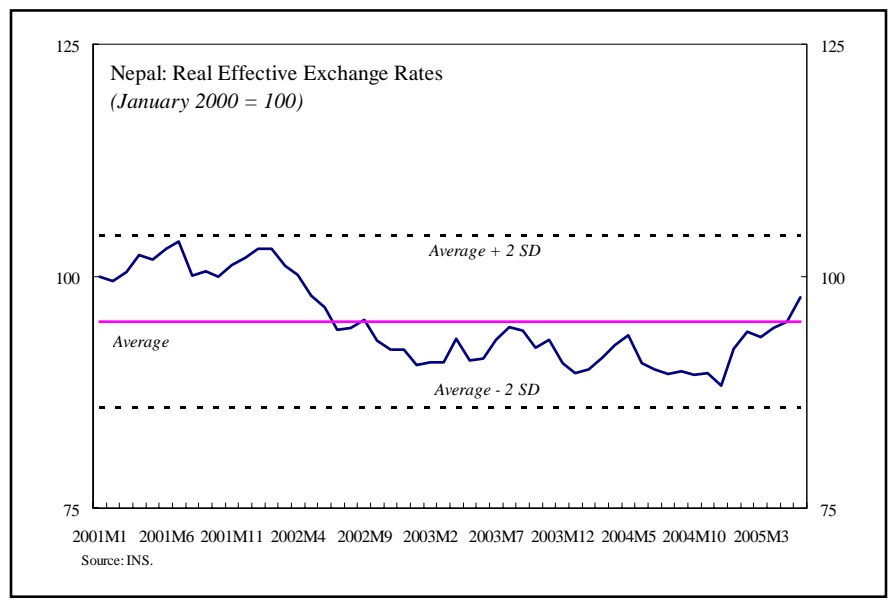
early 2005, faster productivity growth in India, and WTO membership have implications for competitiveness and would require that the level of the peg be kept under review. ${ }^{13}$ However, improvements in the business climate and investment in infrastructure are key to raising competitiveness by raising productivity and labor market flexibility, reducing transportation and transactions costs, and easing supply bottlenecks. ${ }^{14}$

\footnotetext{
${ }^{13}$ Nepal became the $147^{\text {th }}$ member of the WTO in April 2004 and has joined a number of regional trading arrangements, including SAFTA and BIMSTEC. See Chapter III, selected issues paper, "Nepal-Meeting the Challenges of Globalization."

${ }^{14}$ For example, on most indices of labor market rigidity in the World Bank survey on Doing Business in 2006, Nepal is above the South Asian average.
} 


\section{B. Structural Reforms}

\section{Financial Sector}

\section{The authorities have made progress in implementing their financial sector} reform strategy since 2002, although much remains to be done. These reforms have been financed by the World Bank and AsDB, and cover three main areas: improvements in the legal framework for financial sector activity; NRB "reengineering" to transform it into an effective central bank; and restructuring of insolvent commercial and development banks to improve financial intermediation.

\section{There was broad consensus on steps needed to further improve the legal}

framework and NRB reengineering. On the legal framework, the authorities are considering amendments in the Banking and Financial Institutions Ordinance (BFIO), possibly higher capital requirements, and other provisions for mergers which could help the financial system consolidate ahead of 2010 when competition would increase under WTO commitments. As regards the NRB "reengineering," a major achievement has been staff reduction through voluntary and compulsory retirement schemes. The NRB now intends to raise professionalism through better performance evaluation and incentives. Efforts are underway to strengthen financial sector supervision, and to raise internal audit and accounting standards.

26. The legal framework for loan recovery has improved. New debt recovery mechanisms (blacklisting directives, the Debt Recovery Tribunal (DRT), and an Appellate Tribunal) have provided financial institutions with additional instruments to enforce contractual obligations, raised awareness about sound banking practices, and led to some recoveries from small- and medium-sized defaulters. However, the banks have been reluctant to pursue many cases in the DRT due to concerns about its limited staff and capacity to enforce rulings.

\section{Progress has been made with restructuring of commercial and development}

banks. External management teams at Nepal Bank Limited (NBL) and Rastriya Banijya Bank (RBB) — the two largest banks which account for 50 percent of banking system deposits-have eliminated the losses of the banks; both banks made profits in 2003/04 and 2004/05. The managers achieved this through voluntary retirement schemes to reduce excess staff and reductions in their deposit rates to lower the cost of funds. They also made

\begin{tabular}{|c|c|c|c|}
\hline \multicolumn{4}{|c|}{ Nepal: Financial Sector Indicators } \\
\hline & $2002 / 03$ & 2003/04 & $2004 / 05$ \\
\hline \multicolumn{4}{|l|}{ Financial institutions (number) } \\
\hline Commercial banks & 17 & 17 & 17 \\
\hline Nonbank financial institutions 1/ & 102 & 106 & 117 \\
\hline Banking system performance indicators & \multicolumn{3}{|c|}{ (In percent) } \\
\hline Capital adequacy (total capital/total risk weighted assets) & -12.0 & -9.1 & -2.6 \\
\hline NBL & -28.3 & -25.0 & -22.2 \\
\hline RBB & -44.3 & -42.1 & -35.0 \\
\hline Other commercial banks & 12.5 & 11.3 & 13.5 \\
\hline Asset quality (NPLs/total loans) & 28.7 & 22.8 & 18.7 \\
\hline NBL & 60.7 & 53.7 & 49.0 \\
\hline RBB & 60.2 & 57.6 & 50.7 \\
\hline Liquidity (liquid assets/total deposits) & 39.9 & 40.5 & 39.4 \\
\hline Profitability (return on assets: net profit or loss /total assets) & -1.1 & 1.2 & 1.5 \\
\hline \multicolumn{4}{|c|}{ Sources: Nepal Rastra Bank; World Bank, Financial Soundness Indicators; and Fund staff estimates. } \\
\hline $\begin{array}{l}\text { 1/ Includes development banks (including rural and microcredit } \\
\text { and cooperatives. }\end{array}$ & relopmen & ks), finan & mpanies, \\
\hline
\end{tabular}


some headway in reducing the negative net worth of the banks. In addition, AsDB supported restructuring plans for Agricultural Development Bank of Nepal (ADBN) have proceeded well, including through a voluntary retirement scheme to reduce excess staff, changes in the management team, and reconstitution of its board of directors. However, no progress has been made with the restructuring of Nepal Industrial Development Corporation (NIDC) even though its financial condition is dismal. ${ }^{15}$ The development bank has NPAs over 85 percent and is a perennial loss-maker. Staff agreed that the NIDC can be privatized given the substantial undervaluation of its fixed assets, and need not necessarily be liquidated. The authorities agreed that NIDC privatization should be done early, transparently, and without any capital injection.

\section{However, loan recovery from large willful defaulters remains contentious.}

Recoveries from these defaulters are required to improve NBL and RBB balance sheets, pave the way for their privatization, and reduce contingent liabilities for the budget. The banks' efforts to seize collateral from defaulters have been stalled by stay orders issued by the judiciary. At the same time, external shocks (e.g., elimination of MFA quotas and slack tourism) and domestic disturbances have made it more difficult for some borrowers to service loans. While accepting that economic conditions are difficult, staff noted that loan nonrepayment is a longstanding problem and needs to be addressed firmly. Staff supported the NRB's view that the government should remain focused on supporting loan recovery. In this context, staff also agreed with the NRB that inconsistencies, if any, in the legal framework - such as those alleged between blacklisting directives and limited liability provisions of the new Company Ordinance — can be handled by the courts. To further the loan recovery process, staff supported full implementation of measures (such as revocation of defaulters' passports) enumerated in a recent high-level committee report.

\section{Public Enterprises and Governance}

29. The authorities acknowledged that public enterprise reforms had lagged. Of the thirty nonfinancial enterprises - operating in industrial, trading, services, and utilities sectors - under full government ownership at end-2002/03, most of which were loss-making, three enterprises have been privatized/liquidated. ${ }^{16}$ An additional five enterprises were to be privatized by early 2005. Progress has been slow due to a combination of factors, including slow decision-making, uncertain market conditions which make potential investors reluctant to bid for enterprises, and court rulings obtained by unions against privatization/liquidation. The authorities intended to press on with privatization/liquidation of loss-making enterprises. They also noted that they were taking other actions to create space for the private sector in

15 The estimated assets of ADBN and NIDC - the two main development banks - at end-2004/05 were 71/2 percent of GDP and 1 percent of GDP, respectively.

${ }^{16}$ Excluding NTC, the annual operating losses of these enterprises are estimated at Nrs $1-1 \frac{1}{2}$ billion ( $1 / 4$ percent of GDP). 
economic activity. These included recent market entry of a second mobile services provider and plans for share offerings in Nepal Telecommunications Corporation.

30. Some progress was made in governance reforms. After the Civil Service Ordinance which was promulgated in July 2005, the authorities are in the final stages of promulgating the Governance Ordinance, a reform supported by AsDB and World Bank programs. This ordinance would clarify responsibilities between the executive and the civil service. Decentralization is also progressing, especially in the health and education sectors through transfer of schools and sub-health posts to local level management, with support from the World Bank and donors. Progress in judicial reforms is slower. Staff encouraged the authorities to make further progress in reducing corruption, noting that domestic stakeholders and the international community believed that governance remains weak.

\section{Regulation and Labor Market}

31. Efforts to improve the regulatory framework and reform the labor market are underway. Staff welcomed the promulgation of four ordinances in September/OctoberSecured Transactions, Company, Securities, and Insolvency-to improve the regulatory environment. A draft Competition Ordinance is also being prepared. As regards labor markets, the government has prepared a draft ordinance with provisions for more flexible contractual hiring, and streamlined procedures for enterprise closure and layoffs. Staff welcomed the flexibility provisions of the draft ordinance, but noted the need to accommodate labor concerns about unemployment insurance and due process provisions to ensure that new provisions balance flexibility with fairness in industrial employment.

\section{Agricultural Sector}

32. Notwithstanding improved performance during the second half of the 1990s, agricultural productivity in Nepal remains low. Crop yields are low relative to neighboring states in India and Bangladesh. Limited availability and use of irrigation and complementary inputs (improved seeds, fertilizers and technical advances), and limited access to markets (especially for the mountainous regions) contribute to these low yields. The size of landholdings had also become smaller progressively during decades of population growth, making it difficult to exploit scale economies in the plains; the hilly areas present problems related to a difficult terrain. The authorities acknowledged that while land reforms have had some success in reducing inequity in landholding in the rural areas, landholders require complementary inputs to raise agricultural productivity (Box 2). They noted that the twenty-year Agricultural Perspective Plan (APP) initiated in 1995 aims to improve the delivery of these inputs and infrastructure to promote commercialization and market access. A number of the policies from the APP are included in the PRSP. 


\section{Box 2. Nepal: Land Reforms and Agricultural Productivity}

\section{Land reforms have often been credited with spurring growth, reducing inequality, and} inducing structural transformation. This is especially the case for East Asian countries. ${ }^{1}$ In these countries, land reforms have improved agricultural growth and productivity, raising living standards, and paving the way for a shift to industrial societies. Greater equality in landholding and lower landlessness in agricultural economies is also associated with lower social and economic conflict. By the same token, landlessness in Nepal is closely associated with the insurgency and intensity of conflict.

\section{In Nepal, land reforms have been undertaken across five decades, with mixed results. ${ }^{2}$} Landmarks in this process include the Land Cultivation Act of 1956, the Land Act of 1957, the Agricultural Reorganization Act of 1963, the Land Reform Act of 1964, the Land Reform Commission of 1994, and the land reforms of 2001. Land reforms in Nepal, as in other South Asian countries, have mostly involved land redistribution from those that have large holdings to the landless or those with small holdings. These efforts have taken the form of a progressive reduction in

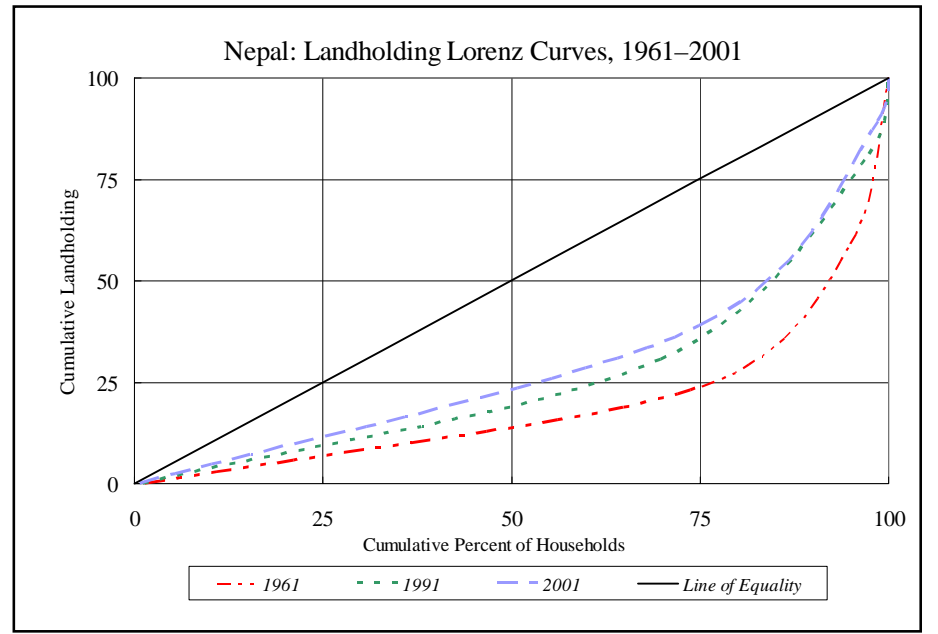
ceilings on land holdings. Efforts have also been made to promote and protect tenancy rights. To some extent, these reforms have reduced land inequality and some reduction in the ratio of landless households. However, with the population increase over the decades, the absolute number of landless households has increased and landholdings have further fragmented. Moreover, other reasons for limited success include the inability of land recipients to assert their rights (due to lack of knowledge and/or illiteracy), the generally low quality of the land that was redistributed, and the lack of complementary inputs.

\section{Experience suggests that complementary inputs need to be in place to raise agricultural} productivity. Without these inputs, the impact of land reforms in Nepal on agricultural productivity would likely remain limited. These inputs include rural finance for irrigation, farm machinery, and fertilizers, and improvements in rural infrastructure to promote commercialization and market access for agricultural produce. A number of these policies are envisaged in the 20-year Agricultural Perspective Plan initiated in 1995 and are included in the PRSP. At the same time, employment generation in urban areas would reduce pressures on land and provide gainful opportunities in nonagriculture.

${ }^{1}$ R. L. Prosterman and T. Hanstad, 2003, "Land Reform in the $21^{\text {st }}$ Century," RDI Reports on Foreign Aid and Development, No. 117.

${ }^{2}$ P.S. Thapa, 2001, "The Cost-Benefit of Land Reform," Himal Magazine. 


\section{PRGF Arrangement}

\section{Performance under the PRGF arrangement which was approved by the} Executive Board in November 2003 to support Nepal's Poverty Reduction Strategy has been mixed. Macroeconomic stability has been maintained. However, structural reforms have progressed at a slower-than-envisaged pace. Progress was made in tax administration, financial sector reforms (framework for banking sector activity, NRB reengineering and restructuring of commercial and development banks), public expenditure management, and decentralization of social sector service delivery. Based on this progress, the first review under the arrangement was completed, with a delay, in October 2004. Since then, the second and third reviews - envisaged to be completed in January and April 2005, respectivelyhave not been completed. Most quantitative performance criteria for the reviews were met (Table 6). A number of structural measures for the second review have also been implemented (Table 7). However, only one measure for the third review has been implemented (Table 8). While implementation in the current political and security conditions remains difficult, donors have expressed a willingness to provide financial assistance if reforms can be undertaken.

\section{Enhanced HIPC and Multilateral Debt Relief Initiatives}

34. The authorities are considering participation in the enhanced HIPC initiative, if found eligible. Based on the ongoing ring-fencing exercise, Nepal was considered potentially eligible — on a preliminary basis — for debt relief under the enhanced HIPC Initiative. As part of the initial work in this exercise, the NPV of external debt for end-2004 was estimated at 200 percent of exports of goods and services. ${ }^{17}$ Since then, a reconciliation of Nepal's external debt database with creditor records has been completed and a final determination on eligibility is expected to be made in early 2006. Preliminary estimates indicate that the combined relief under the enhanced HIPC and Multilateral Debt Relief (MDR) Initiatives could be up to US $\$ 1 / 4$ billion in NPV terms ( 85 percent of exports of goods and services). The authorities recognized that these initiatives provide an opportunity to reduce significantly external debt obligations if Nepal can implement its reform agenda.

\section{E. Other Issues}

35. The NRB is taking steps to follow through on safeguards issues. The international auditor has finalized 2003/04 NRB accounts, a performance criterion for the third review, and the Auditor General has appointed an international auditor for 2004/05. The Financial Management Department is making efforts to adopt international accounting standards (IFRS), and the Internal Audit Department is also being strengthened. However, weaknesses

${ }^{17}$ This NPV computation generates a higher NPV-to-exports ratio than the LIC-DSA due to the use of currency specific discount rates, which are currently lower than the LIC-DSA discount rate. 
identified by the external auditors in internal control and reporting systems remain to be addressed.

36. The authorities expressed satisfaction with past IMF technical assistance and discussed future needs. They noted that technical assistance to the NRB-monetary operations and public debt management-had helped implement the new framework for monetary operations. Further assistance is required in improving tax administration, preferably through a long term advisor. The authorities sought further assistance to address statistical weaknesses (Annex VI), especially to improve national income accounts and to construct trade price indices.

37. The authorities are taking steps to improve external debt data management to ensure accurate monitoring of external obligations. This would help ensure that such incidents as the recent misreporting of external arrears related to the second disbursement under the PRGF arrangement do not recur and payments are made on a timely basis. The second disbursement under the arrangement was made in November 2004 on the basis of a finding that all conditions applicable to the disbursement, including on the nonaccumulation of external payment arrears, had been met. This finding later proved incorrect, as discussions with the authorities revealed that Nepal had accumulated external payment arrears to Austria, including between November 2003 and October 2004. As a result, the disbursement made in November 2004 was noncomplying. The arrears which led to the noncomplying disbursement have been cleared. The arrears are attributable to weak debt management and coordination problems. The authorities are making a good-faith effort to service their debt in a timely manner, strengthen debt management, and improve coordination. In light of these corrective actions, it has been recommended that the Executive Board grant a waiver for Nepal's nonobservance of the continuous performance criterion on the nonaccumulation of external payment arrears.

\section{StAFF Appraisal}

38. Nepal's growth performance has deteriorated and poverty remains high. Unsettled political conditions and the insurgency have increasingly contributed to lower growth. Notwithstanding a decline during the last decade, poverty remains high and Nepal lags in human development indicators. The main causes include inefficient resource allocation in key sectors, and poor governance and social service delivery.

39. The PRSP strategy, reflecting the consensus of stakeholders across the political spectrum, remains appropriate. To effectively implement this strategy and improve growth prospects, resolution of the political uncertainties, improved security, and progress towards peace are essential. Over the medium term, continued macroeconomic stability, institution building, and structural reform are required to generate high, sustained growth and further reduce poverty. 
40. Prudent fiscal policies in the past have helped maintain macroeconomic stability. Efforts to raise the revenue-to-GDP ratio, increase social sector spending, and limit domestic financing are commendable. Prioritization of expenditures as part of the MTEF is welcome.

41. Looking forward, continued efforts to mobilize revenue, contain expenditure, and limit domestic financing are required to ensure medium-term fiscal sustainability. On revenues, there is considerable scope for improvements in tax administration, especially customs, excises, and LTO operations to raise collections. As regards expenditure, low levels of development spending, especially on foreign-financed infrastructure projects, continue to dampen growth and restrict the achievement of PRSP objectives. External assistance and development spending need to be raised, and domestically financed deficits limited to levels consistent with fiscal sustainability. This requires implementing PRSP reforms, which will help bring donor programs back on track. Contingent liabilities from banking and public enterprise reforms should also be addressed, with donor assistance. To ensure that the NOC does not pose an additional burden on the budget, a full pass-through of higher international oil prices and implementation of an automatic pricing mechanism are essential.

42. Fiscal transparency and improved public expenditure management can help alleviate donor concerns about the quality of spending and improve resource allocation. For this, implementation of fiscal ROSC recommendations would be key. The MTEF can be further strengthened and pro-poor expenditure increased, primarily through better costing and enhanced reporting of outcomes.

43. Monetary and exchange rate policies to support the exchange rate peg to the Indian rupee remain appropriate; the level of the peg should be kept under review. The peg enables the economy to benefit from close economic ties with India, provides policy credibility by importing stable monetary conditions, and keeps inflation at low levels. Nevertheless, Nepal's continuing integration with the global and regional economy and external shocks require that the level of the peg be kept under review. External competitiveness is best addressed by structural reforms and infrastructure investments to reduce input costs and supply bottlenecks.

44. While financial sector reforms have progressed, much remains to be done. Commendable progress has been made in improving the legal and debt recovery frameworks, NRB reengineering, and restructuring of RBB, NBL, and ADBN. Nevertheless, the legal framework for financial sector activity can be further improved by amending the BFIO. Further progress can be made at the NRB to improve staff performance and professionalism, enhance financial sector supervision, and raise internal audit and accounting standards. While the operations of the DRT need to be enhanced by increasing its staffing and budgetary resources, significant loan recoveries from large, willful defaulters are required to improve the balance sheets of RBB and NBL. This requires full implementation of recommendations contained in the recent high-level committee report. The delay in NIDC restructuring needs to be addressed by privatizing it promptly and transparently. 
45. Significant progress is required in public enterprise and governance reforms to increase the efficiency, credibility and accountability of government operations. Liquidation of unviable loss-making enterprises should proceed decisively. Other mechanisms - such as share sales and management contracts-should be actively pursued for large public enterprises to improve their efficiency. Staff welcomes the adoption of the Civil Service Ordinance to improve governance, and urges early promulgation of the Governance Ordinance. Anti-corruption efforts need to focus on large and prominent offenders to yield measurable results. Improving voice, accountability and service delivery requires further decentralization. Judicial reforms would help enforce the rule of law.

\section{To foster private sector led growth, the regulatory framework needs to be} upgraded and labor markets made more flexible. The promulgation of Secured Transactions, Company, Securities, and Insolvency Ordinances is a step in the right direction. By meeting its obligations under multilateral and regional trading arrangements, Nepal could further upgrade its regulatory framework to international standards. Staff urges early promulgation of the draft Labor Ordinance, after due consultation with all stakeholders to ensure that its provisions are durable and implementable.

\section{Effective implementation of the Agricultural Perspective Plan can raise} productivity. In particular, policies to increase rural finance for complementary inputs, and better rural infrastructure to promote commercialization and market access are essential. Land reforms will likely have limited success without these supportive policies.

\section{Data deficiencies need to be addressed to improve policy formulation and} monitoring. Data provision to the Fund is generally adequate for policy surveillance. Efforts to improve statistics notwithstanding, significant gaps remain. Staff encourages the authorities to make use of STA technical assistance and fully implement its recommendations.

49. Staff welcome efforts to strengthen external debt data management and recommends that the Executive Board grant a waiver for Nepal's nonobservance of the continuous performance criterion on the nonaccumulation of external payment arrears related to the second disbursement under the PRGF arrangement.

50. It is recommended that the next Article IV consultation with Nepal be held within 24 months, subject to the applicable Executive Board decision on consultation cycles. 
Figure 1. Nepal: Economic Developments

The conflict has contributed to real GDP growth slowdown....

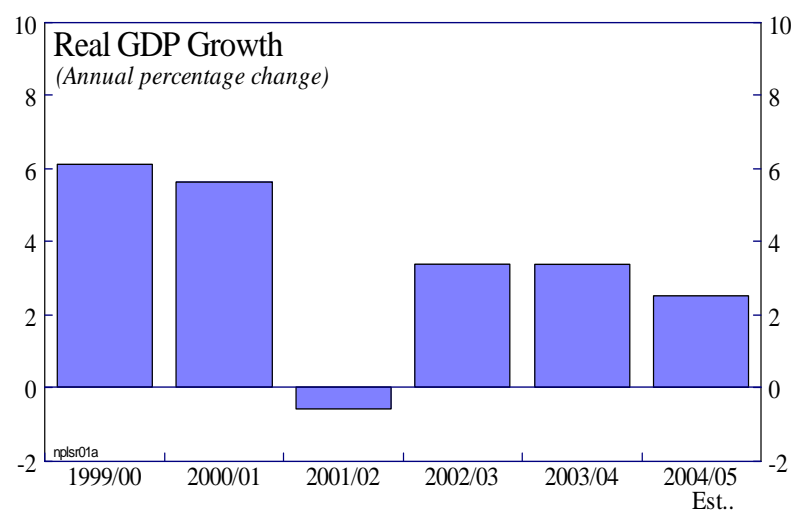

Meanwhile, low development spending and revenue mobilization...

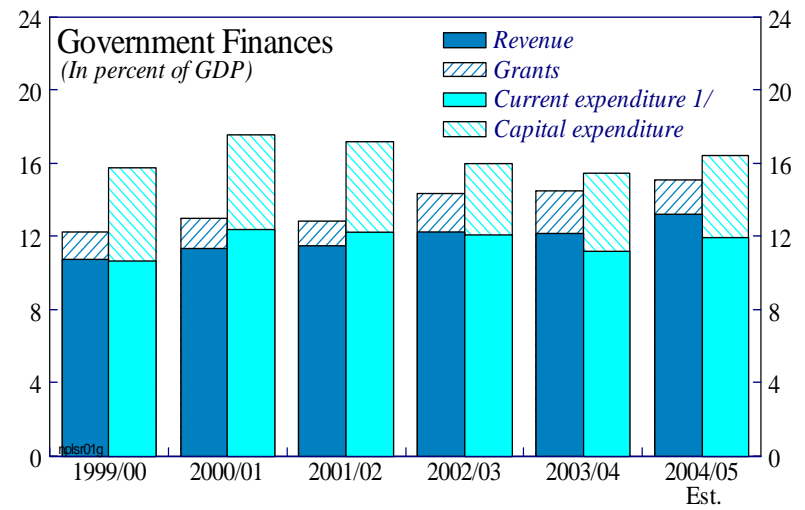

High remittance inflows have offset weak export performance, and together with low imports...

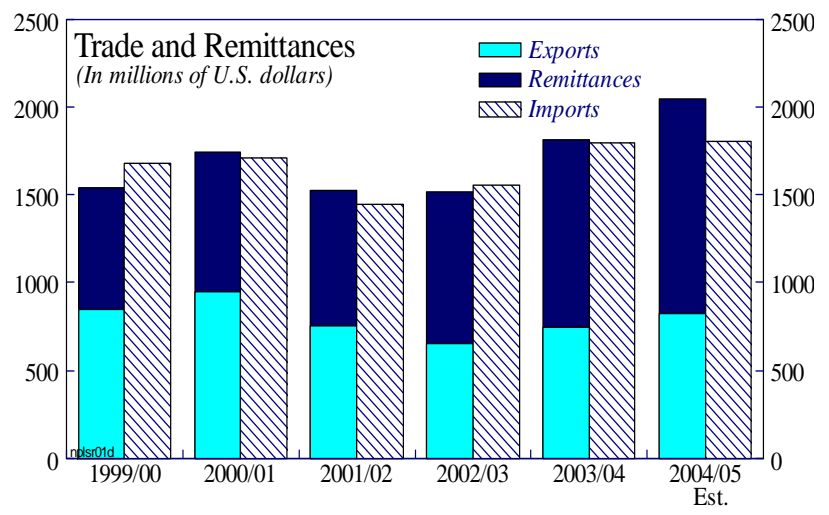

... and supply side disruptions have recently led to higher inflation.

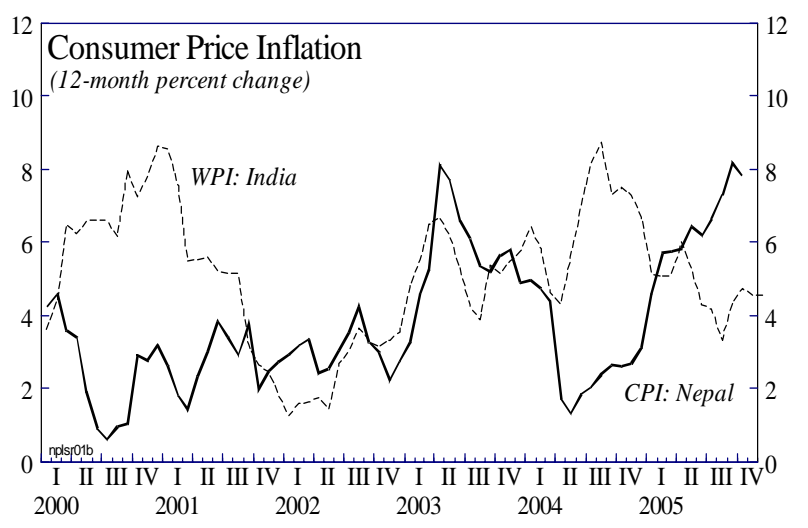

... have helped keep deficits low.

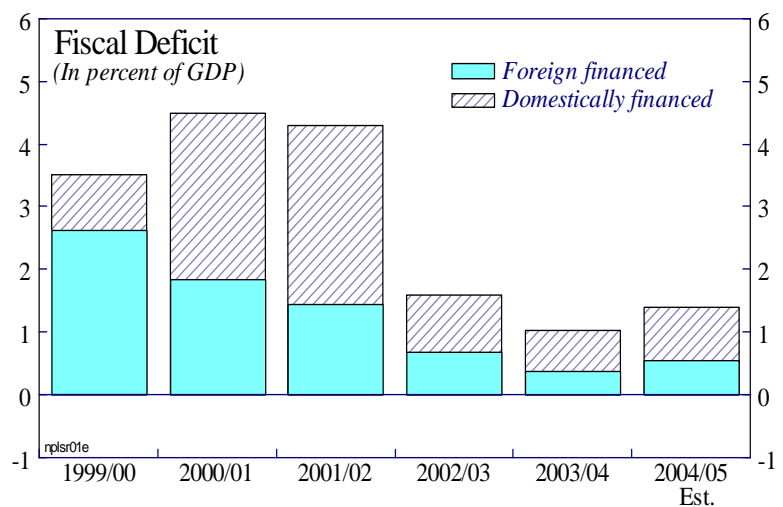

... allowed a buildup of international reserves.

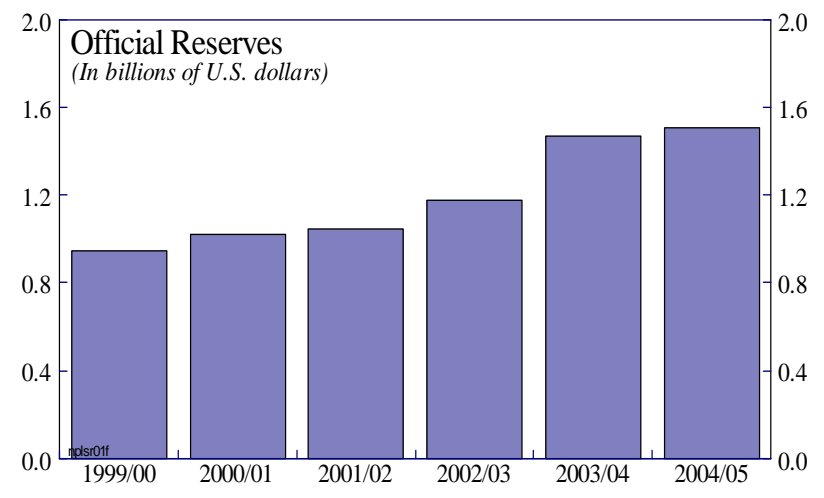

Sources: Data provided by the Nepalese authorities; IMF, International Financial Statistics; and staff estimates.

1/ Includes net lending. 
Table 1. Nepal: Selected Economic Indicators, 2000/01-2005/06 1/

Nominal GDP (2004/05): US\$7,359 million

Population (2004/05): 25.2 million

GDP per capita (2004/05): US\$292

Poverty rate: 31 percent $(2003 / 04)$

Main exports: Textiles and clothing

Quota: SDR 71.3 million

\begin{tabular}{lllllll}
$2000 / 01$ & $2001 / 02$ & $2002 / 03$ & $2003 / 04$ & & $2004 / 05$ & 2005/06 \\
\cline { 3 - 4 } & & Prog. & Est. & Prog. & Est. & Proj.
\end{tabular}

\begin{tabular}{|c|c|c|c|c|c|c|c|c|}
\hline Real GDP at market prices & 5.6 & -0.6 & 3.4 & 3.5 & 3.4 & 4.0 & 2.5 & $21 / 2-31 / 2$ \\
\hline CPI (12-month change) & 3.4 & 3.5 & 6.1 & 4.5 & 2.0 & 5.5 & 6.6 & $7-9$ \\
\hline CPI (period average) & 2.4 & 2.9 & 4.7 & 5.3 & 4.0 & 4.4 & 4.5 & $7-9$ \\
\hline GDP deflator & 2.6 & 3.4 & 4.5 & 4.9 & 5.0 & 5.5 & 4.1 & 5.0 \\
\hline Fiscal indicators 1/ & \multicolumn{8}{|c|}{ (In percent of GDP) } \\
\hline Total revenue & 11.4 & 11.5 & 12.3 & 12.4 & 12.2 & 13.3 & 13.0 & 13.6 \\
\hline Total expenditure & 17.5 & 17.2 & 16.0 & 18.7 & 15.5 & 18.7 & 16.0 & 17.3 \\
\hline Current expenditure & 11.1 & 11.5 & 11.4 & 13.1 & 11.2 & 13.0 & 11.7 & 12.8 \\
\hline Capital expenditure and net lending & 6.4 & 5.6 & 4.6 & 5.6 & 4.3 & 5.7 & 4.3 & 4.5 \\
\hline Overall deficit before grants & 6.1 & 5.7 & 3.7 & 6.3 & 3.3 & 5.3 & 3.0 & 3.7 \\
\hline Overall deficit after grants & 4.5 & 4.3 & 1.6 & 3.1 & 1.0 & 2.5 & 0.9 & 1.2 \\
\hline Domestic financing (net) & 2.7 & 2.9 & 0.9 & 1.7 & 0.6 & 0.7 & 0.4 & 0.8 \\
\hline Public debt & 63.6 & 67.9 & 67.2 & 65.8 & 65.2 & 60.0 & 60.8 & 57.8 \\
\hline Money and credit & \multicolumn{8}{|c|}{ (Percent change, end-of-period) } \\
\hline Broad money & 15.2 & 4.4 & 9.8 & 11.1 & 12.7 & 13.3 & 8.0 & 9.0 \\
\hline Domestic credit & 18.8 & 9.2 & 12.0 & 13.7 & 9.3 & 11.5 & 13.3 & 11.0 \\
\hline Velocity & 1.9 & 1.9 & 1.9 & 1.8 & 1.8 & 1.7 & 1.7 & 1.7 \\
\hline Interest rates & \multicolumn{8}{|c|}{ (In percent) } \\
\hline 91-day treasury bill (end-of-period) & 5.0 & 3.6 & 4.0 & $\ldots$ & 1.5 & $\ldots$ & 3.7 & $\ldots$ \\
\hline Central bank refinancing & $61 / 2-71 / 2$ & $2-5^{1 / 2}$ & $2-5 \frac{1}{2}$ & $\ldots$ & $2-51 / 2$ & $\ldots$ & $1 \frac{1 / 2-51 / 2}{1}$ & $\ldots$ \\
\hline Loans to industry & $9 \frac{1}{2}-15$ & $7-14 \frac{1}{2}$ & $7-14 \frac{1}{2}$ & $\ldots$ & $6^{1 / 2-13}$ & $\ldots$ & $61 / 2-13$ & $\ldots$ \\
\hline Balance of payments & \multicolumn{8}{|c|}{ (In millions of U.S. dollars) } \\
\hline Current account balance (excluding grants) & 162 & 106 & 16 & -109 & 59 & -163 & 226 & 174 \\
\hline In percent of GDP & 2.9 & 1.9 & 0.3 & -1.7 & 0.9 & -2.2 & 3.1 & 2.2 \\
\hline Trade balance & -765 & -694 & -904 & $-1,098$ & $-1,053$ & $-1,287$ & -980 & $-1,101$ \\
\hline In percent of GDP & -13.7 & -12.5 & -15.4 & -17.1 & -15.6 & -18.4 & -13.3 & -13.8 \\
\hline Foreign direct investment & -0.4 & -3.7 & 12.4 & $\ldots$ & 1.9 & $\ldots$ & 2.0 & 15.0 \\
\hline In percent of GDP & 0.0 & -0.1 & 0.2 & $\ldots$ & 0 & $\ldots$ & 0 & 0.2 \\
\hline Gross official reserves (end-of-period) & 1,020 & 1,048 & 1,178 & 1,233 & 1,471 & 1,568 & 1,507 & 1,551 \\
\hline In months of imports of goods and services & 7.2 & 7.0 & 6.6 & 6.4 & 8.2 & 6.8 & 7.6 & 6.7 \\
\hline Export value growth $2 /$ & 5.5 & -18.4 & 5.6 & 7.4 & 14.7 & 6.9 & 10.4 & 10.1 \\
\hline Import value growth & 1.9 & -15.3 & 7.5 & 9.0 & 15.8 & 15.5 & 0.3 & 11.3 \\
\hline External debt/GDP (in percent) 3/ & 49.8 & 52.7 & 52.6 & 47.2 & 51.0 & 43.7 & 47.1 & 44.5 \\
\hline Debt service 4/ & 4.2 & 4.9 & 5.0 & 6.0 & 4.5 & 5.0 & 4.6 & 4.6 \\
\hline Exchange rate (Nrs per U.S. dollar, end-of-period) & 74.7 & 78.0 & 74.8 & $\ldots$ & 74.1 & $\ldots$ & 70.0 & $\ldots$ \\
\hline REER (end-of-period; percent change; negative = depreciation) & 3.8 & -9.2 & -7.2 & $\ldots$ & -3.4 & $\ldots$ & $\ldots$ & $\ldots$ \\
\hline NEER (end-of-period; percent change) & 2.9 & -11.2 & -2.0 & $\ldots$ & -2.3 & $\ldots$ & 4.6 & $\ldots$ \\
\hline \multicolumn{9}{|l|}{ Fund operations (outstanding loans at end-of-period; SDR millions) } \\
\hline SAF/ESAF/PRGF & 7.8 & 4.5 & 1.7 & $\ldots$ & 7.1 & $\ldots$ & 14.3 & $\ldots$ \\
\hline Nominal GDP at market prices (Nrs billions) & 411.3 & 422.8 & 456.7 & 484.3 & 495.6 & 539.9 & 529.0 & 572.0 \\
\hline
\end{tabular}

Sources: Data provided by the Nepalese authorities; and Fund staff estimates and projections.

1/ Fiscal year begins mid-July. For 2004/05, figures relate to the revised January 2005 budget.

2/ Excluding re-exports.

$3 /$ Includes estimated short-term trade credits.

4/ In percent of exports of goods, services, excluding reexports and private transfers; including debt service to the Fund. 
Table 2. Nepal: Summary of Government Operations, 2003/04-2007/08 1/

\begin{tabular}{|c|c|c|c|c|c|c|c|c|c|}
\hline & \multicolumn{2}{|c|}{$2003 / 04$} & \multicolumn{3}{|c|}{$2004 / 05$} & \multicolumn{2}{|c|}{$2005 / 06$} & \multirow{2}{*}{$\frac{2006 / 07}{\text { Proj }}$} & \multirow{2}{*}{$\frac{2007 / 08}{\text { Proj }}$} \\
\hline & Budget & itcome & $\begin{array}{c}\text { Budget/ } \\
\text { Program }\end{array}$ & $\begin{array}{r}\text { Revised } \\
\text { Budget }\end{array}$ & $\begin{array}{l}\text { Outcome } \\
\text { Estimate }\end{array}$ & Budget & Proj & & \\
\hline & \multicolumn{9}{|c|}{ (In billions of Nepalese rupees) } \\
\hline Total revenue and grants & 75.7 & 71.8 & 83.7 & 87.3 & 79.9 & 98.9 & 92.1 & 98.3 & 107.7 \\
\hline Total revenue & 60.2 & 60.5 & 68.3 & 71.9 & 68.9 & 80.3 & 77.8 & 84.8 & 92.7 \\
\hline Tax revenue & 48.2 & 48.2 & 53.8 & 56.0 & 54.1 & 63.9 & 62.3 & 67.7 & 74.5 \\
\hline Nontax revenue $2 /$ & 12.0 & 12.3 & 14.6 & 16.0 & 14.8 & 16.4 & 15.4 & 17.1 & 18.3 \\
\hline Grants & 15.5 & 11.3 & 15.4 & 15.4 & 11.1 & 18.7 & 14.3 & 13.5 & 15.0 \\
\hline Total expenditure & 90.7 & 76.8 & 97.2 & 100.8 & 84.5 & 111.5 & 99.0 & 111.5 & 125.3 \\
\hline Current & 63.5 & 55.6 & 67.6 & 70.1 & 61.6 & 75.8 & 73.4 & 81.7 & 90.6 \\
\hline Of which: interest payments & 7.9 & 6.5 & 7.6 & 7.6 & 6.2 & 7.4 & 7.4 & 8.2 & 9.3 \\
\hline Capital and net lending & 27.2 & 21.2 & 29.6 & 30.7 & 22.9 & 35.7 & 25.7 & 29.7 & 34.6 \\
\hline Overall balance before grants & -30.5 & -16.3 & -28.9 & -28.9 & -15.6 & -31.3 & -21.3 & -26.7 & -32.5 \\
\hline Overall balance after grants & -15.0 & -5.0 & -13.5 & -13.5 & -4.6 & -12.6 & -7.0 & -13.2 & -17.5 \\
\hline Financing & 15.0 & 5.0 & 13.5 & 13.5 & 4.6 & 12.6 & 7.0 & 13.2 & 17.5 \\
\hline Net foreign loans & 6.7 & 1.9 & 10.0 & 10.0 & 2.5 & 8.0 & 2.6 & 7.9 & 12.0 \\
\hline Gross disbursements & 12.8 & 7.6 & 17.0 & 17.0 & 8.4 & 14.5 & 9.2 & 15.0 & 20.0 \\
\hline Amortization & 6.1 & 5.8 & 7.0 & 7.0 & 6.0 & 6.5 & 6.7 & 7.1 & 8.0 \\
\hline Net domestic financing & 8.4 & 3.2 & 3.5 & 3.5 & 2.1 & 4.6 & 4.4 & 5.2 & 5.5 \\
\hline Net NRB financing & 1.0 & -5.4 & 0.5 & $\ldots$ & -0.9 & $\ldots$ & 1.0 & $\ldots$ & $\ldots$ \\
\hline Net commercial bank & 7.0 & 4.3 & 2.5 & $\ldots$ & 4.8 & $\ldots$ & 3.0 & $\ldots$ & $\ldots$ \\
\hline \multirow[t]{2}{*}{ Net nonbank } & 0.4 & 4.3 & 0.5 & $\ldots$ & -1.8 & $\ldots$ & 0.4 & $\ldots$ & $\ldots$ \\
\hline & \multicolumn{9}{|c|}{ (In percent of GDP) } \\
\hline Total revenue & 12.4 & 12.2 & 12.7 & 13.3 & 13.0 & 13.6 & 13.6 & 13.6 & 13.7 \\
\hline Tax revenue & 9.9 & 9.7 & 10.0 & 10.4 & 10.2 & 10.8 & 10.9 & 10.9 & 11.0 \\
\hline Nontax revenue $2 /$ & 2.5 & 2.5 & 2.7 & 3.0 & 2.8 & 2.8 & 2.7 & 2.7 & 2.7 \\
\hline Grants & 3.2 & 2.3 & 2.8 & 2.8 & 2.1 & 3.2 & 2.5 & 2.2 & 2.2 \\
\hline Total expenditure & 18.7 & 15.5 & 18.0 & 18.7 & 16.0 & 18.9 & 17.3 & 17.9 & 18.5 \\
\hline Current & 13.1 & 11.2 & 12.5 & 13.0 & 11.7 & 12.8 & 12.8 & 13.1 & 13.4 \\
\hline Of which: interest payment & 1.6 & 1.3 & 1.4 & 1.4 & 1.2 & 1.3 & 1.3 & 1.3 & 1.4 \\
\hline Capital and net lending & 5.6 & 4.3 & 5.5 & 5.7 & 4.3 & 6.0 & 4.5 & 4.8 & 5.1 \\
\hline Overall balance before grants & -6.3 & -3.3 & -5.3 & -5.3 & -3.0 & -5.3 & -3.7 & -4.3 & -4.8 \\
\hline Overall balance after grants & -3.1 & -1.0 & -2.5 & -2.5 & -0.9 & -2.1 & -1.2 & -2.1 & -2.6 \\
\hline Financing & 3.1 & 1.0 & 2.5 & 2.5 & 0.9 & 2.1 & 1.2 & 2.1 & 2.6 \\
\hline Net foreign loans & 1.4 & 0.4 & 1.8 & 1.8 & 0.5 & 1.4 & 0.5 & 1.3 & 1.8 \\
\hline Gross disbursements & 2.6 & 1.5 & 3.1 & 3.1 & 1.6 & 2.5 & 1.6 & 2.4 & 2.9 \\
\hline Amortization & 1.3 & 1.2 & 1.3 & 1.3 & 1.1 & 1.1 & 1.2 & 1.1 & 1.2 \\
\hline Net domestic financing & 1.7 & 0.6 & 0.7 & 0.7 & 0.4 & 0.8 & 0.8 & 0.8 & 0.8 \\
\hline Central bank financing & 0.2 & -1.1 & 0.1 & $\ldots$ & -0.2 & $\ldots$ & 0.2 & $\ldots$ & $\ldots$ \\
\hline Commercial bank financing & 1.4 & 0.9 & 0.5 & $\ldots$ & 0.9 & $\ldots$ & 0.5 & $\ldots$ & $\ldots$ \\
\hline Nonbank financing & 0.1 & 0.9 & 0.1 & $\ldots$ & -0.3 & $\ldots$ & 0.1 & $\ldots$ & $\ldots$ \\
\hline \multicolumn{10}{|l|}{ Memorandum items: } \\
\hline Public savings & -0.7 & 1.0 & 0.1 & 0.3 & 1.4 & 0.7 & 0.8 & 0.5 & 0.3 \\
\hline Primary balance & -1.5 & 0.3 & -1.1 & -1.1 & 0.3 & -0.9 & 0.1 & -0.8 & -1.2 \\
\hline Debt service & 3.6 & 3.5 & 3.7 & 3.7 & 3.7 & 3.6 & 3.7 & 3.7 & 3.9 \\
\hline Domestic & 1.8 & 1.9 & 1.9 & 1.9 & 2.2 & 2.1 & 2.1 & 2.1 & 2.1 \\
\hline Foreign & 1.8 & 1.6 & 1.8 & 1.8 & 1.5 & 1.5 & 1.6 & 1.7 & 1.8 \\
\hline Public debt & 65.8 & 65.2 & 60.0 & 60.0 & 60.8 & 59.9 & 57.8 & 56.4 & 55.3 \\
\hline Domestic & 18.6 & 17.1 & 15.6 & 15.6 & 16.4 & 15.8 & 16.0 & 15.5 & 15.0 \\
\hline External & 47.2 & 48.1 & 44.3 & 44.3 & 44.4 & 44.1 & 41.8 & 40.8 & 40.2 \\
\hline Education expenditure & 3.0 & 2.9 & 3.3 & 3.3 & 3.1 & 3.6 & $\ldots$ & $\ldots$ & $\ldots$ \\
\hline Health expenditure & 1.0 & 0.8 & 1.2 & 1.2 & 0.9 & 1.3 & $\cdots$ & $\cdots$ & \\
\hline Nominal GDP (Nrs billions) & 484.3 & 495.6 & 539.9 & 539.9 & 529.0 & 590.8 & 572.0 & 621.7 & 678.8 \\
\hline
\end{tabular}

Sources: Data provided by the Nepalese authorities; and Fund staff estimates.

1/ Fiscal years start mid-July. Table confined to central government operations as contained in the budget.

$2 /$ Includes privatization receipts. 
Table 3. Nepal: Monetary Accounts, 2002/03-2005/06

\begin{tabular}{|c|c|c|c|c|c|c|c|}
\hline & \multirow{2}{*}{$\begin{array}{r}\text { 2002/03 } \\
\text { Jul. }\end{array}$} & \multirow{2}{*}{$\begin{array}{r}\text { 2003/04 } \\
\text { Jul. }\end{array}$} & \multicolumn{4}{|c|}{$2004 / 2005$} & \multirow{2}{*}{$\begin{array}{r}2005 / 06 \\
\text { Jul. } \\
\text { Proj. }\end{array}$} \\
\hline & & & Oct. & Jan. & Apr. & $\overline{\text { Jul. }}$ & \\
\hline Monetary authorities & \multicolumn{7}{|c|}{ (In billions of Nepalese rupees) } \\
\hline Reserve money & 81.0 & 94.4 & 88.3 & 86.0 & 93.1 & 93.9 & 101.4 \\
\hline Net foreign assets & 87.7 & 108.2 & 107.2 & 107.1 & 107.3 & 103.9 & 107.5 \\
\hline \multirow[t]{2}{*}{ Net domestic assets } & -6.7 & -13.8 & -19.0 & -21.1 & -14.2 & -9.9 & -6.1 \\
\hline & \multicolumn{7}{|c|}{ (Annual percentage change) } \\
\hline \multirow[t]{2}{*}{ Reserve money } & 2.5 & 16.6 & 13.2 & 9.6 & 5.6 & -0.5 & 8.0 \\
\hline & \multicolumn{7}{|c|}{ (12-month change in percent of reserve money at start of period) } \\
\hline Reserve money & 2.5 & 16.6 & -6.5 & -8.9 & -1.4 & -0.5 & 8.0 \\
\hline Net foreign assets & 8.3 & 25.4 & -1.0 & -1.1 & -1.0 & -4.6 & 3.9 \\
\hline Net domestic assets & -5.8 & -8.8 & -5.5 & -7.8 & -0.4 & 4.1 & 4.1 \\
\hline Monetary survey & \multicolumn{7}{|c|}{ (In billions of Nepalese rupees) } \\
\hline Broad money & 245.9 & 277.2 & 282.0 & 289.3 & 294.4 & 299.3 & 326.2 \\
\hline Narrow money & 83.8 & 94.0 & 93.9 & 95.7 & 100.5 & 98.9 & 109.1 \\
\hline Quasi money 1/ & 162.2 & 183.2 & 188.1 & 193.6 & 193.9 & 199.9 & 217.1 \\
\hline Net foreign assets & 91.4 & 108.5 & 106.4 & 108.9 & 112.8 & 109.1 & 113.6 \\
\hline Net domestic assets & 154.5 & 168.7 & 175.7 & 180.3 & 181.6 & 190.1 & 212.6 \\
\hline Domestic credit 1/ & 224.3 & 245.2 & 255.3 & 258.4 & 263.8 & 277.8 & 308.3 \\
\hline Public sector & 61.5 & 59.8 & 60.7 & 58.3 & 56.1 & 68.0 & 72.0 \\
\hline Government & 58.7 & 57.6 & 56.8 & 54.8 & 53.0 & 61.5 & 65.5 \\
\hline Public enterprises & 2.8 & 2.2 & 3.9 & 3.6 & 3.0 & 6.5 & 6.5 \\
\hline Private sector & 162.8 & 185.4 & 194.6 & 200.1 & 207.7 & 209.8 & 236.4 \\
\hline \multirow[t]{2}{*}{ Other items, net $2 /$} & -69.8 & -76.5 & -79.6 & -78.1 & -82.2 & -87.7 & -95.8 \\
\hline & \multicolumn{7}{|c|}{ (Annual percentage change) } \\
\hline Broad money & 9.8 & 12.7 & 14.0 & 12.6 & 9.4 & 8.0 & 9.0 \\
\hline Narrow money & 8.6 & 12.2 & 16.5 & 15.3 & 13.4 & 6.7 & 10.3 \\
\hline Quasi money & 10.4 & 13.0 & 12.8 & 11.3 & 7.5 & 8.6 & 8.6 \\
\hline Domestic credit & 12.0 & 9.3 & 11.5 & 14.6 & 15.2 & 13.3 & 11.0 \\
\hline Public sector & 4.9 & -2.7 & -0.4 & 11.1 & 3.4 & 13.6 & 5.9 \\
\hline Government & 5.6 & -1.8 & -3.0 & 10.0 & 3.5 & 6.7 & 6.5 \\
\hline \multirow[t]{2}{*}{ Private sector credit } & 14.9 & 13.9 & 15.9 & 15.7 & 18.9 & 13.2 & 12.6 \\
\hline & \multicolumn{7}{|c|}{ (12-month change in percent of broad money at start of period) } \\
\hline Broad money & 9.8 & 12.7 & 1.7 & 4.3 & 6.2 & 8.0 & 9.0 \\
\hline Net foreign assets & 1.3 & 6.9 & -0.8 & 0.2 & 1.6 & 0.2 & 1.5 \\
\hline Net domestic assets & 8.5 & 5.8 & 2.5 & 4.2 & 4.6 & 7.7 & 7.5 \\
\hline Domestic credit & 10.7 & 8.5 & 3.6 & 4.8 & 6.7 & 11.8 & 10.2 \\
\hline Private sector & 9.4 & 9.2 & 3.3 & 5.3 & 8.1 & 8.8 & 8.9 \\
\hline
\end{tabular}

Sources: Data provided by the authorities; and staff estimates and projections.

1/ Commercial bank data are subject to revisions due to reporting lags.

2/ Includes overdraft at NRB (Nrs 2.6 billion in July 2004/05; zero elsewhere). 
Table 4. Nepal: Balance of Payments, 2000/01-2009/10

\begin{tabular}{|c|c|c|c|c|c|c|c|c|c|c|}
\hline & \multirow[t]{2}{*}{$2000 / 01$} & \multirow[t]{2}{*}{ 2001/02 } & \multirow[t]{2}{*}{$2002 / 03$} & \multirow[t]{2}{*}{ 2003/04 } & \multirow{2}{*}{$\begin{array}{r}2004 / 05 \\
\text { Prel. }\end{array}$} & $2005 / 06$ & $2006 / 07$ & $2007 / 08$ & $2008 / 09$ & $2009 / 10$ \\
\hline & & & & & & \multicolumn{5}{|c|}{ Proj. } \\
\hline & \multicolumn{10}{|c|}{ (In millions of U.S. dollars, unless otherwise stated) } \\
\hline Current account & 270 & 249 & 150 & 200 & 405 & 370 & 362 & 356 & 326 & 279 \\
\hline Current account (excluding official transfers) & 162 & 106 & 16 & 59 & 226 & 174 & 179 & 157 & 125 & 75 \\
\hline Trade balance & -765 & -694 & -904 & $-1,053$ & -980 & $-1,101$ & $-1,181$ & $-1,282$ & $-1,416$ & $-1,522$ \\
\hline Exports, f.o.b. & 945 & 754 & 653 & 748 & 826 & 910 & 1,184 & 1,287 & 1,392 & 1,511 \\
\hline Merchandise exports & 758 & 618 & 653 & 748 & 826 & 910 & 979 & 1,064 & 1,159 & 1,267 \\
\hline Re-exports of oil $1 /$ & 187 & 136 & 0 & 0 & 0 & 0 & 204 & 223 & 233 & 243 \\
\hline Imports, f.o.b. & 1,710 & 1,448 & 1,556 & 1,801 & 1,806 & 2,011 & 2,365 & 2,569 & 2,808 & 3,032 \\
\hline Oil products & 338 & 288 & 242 & 273 & 370 & 475 & 691 & 711 & 728 & 749 \\
\hline Other imports & 1,372 & 1,160 & 1,314 & 1,528 & 1,436 & 1,536 & 1,674 & 1,858 & 2,080 & 2,283 \\
\hline Services (net) & 123 & 64 & 93 & 125 & 6 & 5 & 3 & 10 & 22 & 36 \\
\hline Receipts & 404 & 319 & 341 & 465 & 359 & 380 & 403 & 430 & 462 & 495 \\
\hline Of which : tourism & 159 & 113 & 151 & 246 & 144 & 160 & 179 & 201 & 226 & 254 \\
\hline Income & 23 & -8 & -10 & -23 & 25 & 27 & 28 & 30 & 32 & 34 \\
\hline Credit & 74 & 56 & 58 & 52 & 109 & 112 & 116 & 119 & 123 & 126 \\
\hline Debit & 51 & 64 & 68 & 75 & 84 & 86 & 88 & 89 & 91 & 93 \\
\hline Current transfers & 889 & 887 & 971 & 1,151 & 1,354 & 1,440 & 1,513 & 1,598 & 1,688 & 1,731 \\
\hline Credit, of which: & 908 & 913 & 1,000 & 1,209 & 1,403 & 1,493 & 1,571 & 1,662 & 1,759 & 1,809 \\
\hline General government 2/ & 108 & 143 & 135 & 141 & 180 & 196 & 183 & 198 & 202 & 204 \\
\hline Workers remittances & 640 & 618 & 697 & 795 & 908 & 994 & 1,064 & 1,144 & 1,236 & 1,278 \\
\hline Recorded & 130 & 165 & 234 & 381 & 606 & 673 & 732 & 799 & 876 & 920 \\
\hline Estimated & 510 & 453 & 463 & 414 & 302 & 321 & 333 & 346 & 360 & 358 \\
\hline Debit & 19 & 26 & 29 & 58 & 48 & 53 & 59 & 64 & 71 & 78 \\
\hline Capital account & 84 & 74 & 69 & 20 & 22 & 24 & 26 & 27 & 29 & 31 \\
\hline Capital transfers & 84 & 74 & 69 & 20 & 22 & 24 & 26 & 27 & 29 & 31 \\
\hline Of which: official grants & 58 & 48 & 42 & 20 & 22 & 24 & 26 & 27 & 29 & 31 \\
\hline Financial account & -416 & -426 & -172 & -298 & -426 & -418 & -315 & -362 & -357 & -308 \\
\hline Direct investment & 0 & -4 & 12 & 2 & 2 & 15 & 17 & 20 & 23 & 26 \\
\hline Portfolio investment & 0 & 0 & 0 & 0 & 0 & 0 & 0 & 0 & 0 & 0 \\
\hline Disbursements & 164 & 105 & 111 & 116 & 128 & 165 & 203 & 271 & 293 & 316 \\
\hline Amortization & 61 & 66 & 71 & 79 & 83 & 90 & 100 & 105 & 109 & 117 \\
\hline Errors and omissions 3/ & 100 & 64 & 45 & 314 & 23 & 0 & 0 & 0 & 0 & 0 \\
\hline Overall balance & 38 & -39 & 93 & 235 & 24 & -24 & 73 & 21 & -1 & 3 \\
\hline Financing & -38 & 39 & -93 & -235 & -24 & -46 & -138 & -81 & -54 & -53 \\
\hline Change in reserve assets (-=increase) & -75 & 51 & -91 & -308 & -35 & -44 & -138 & -81 & -52 & -48 \\
\hline IMF purchases (net) & -5 & -4 & -4 & 8 & 11 & 0 & 0 & 0 & -2 & -4 \\
\hline Other liabilities & 42 & -8 & 1 & 65 & 0 & 0 & 0 & 0 & 0 & 0 \\
\hline Exceptional finacing & 0.3 & 0.3 & 0.3 & 0.3 & 0.5 & -1.7 & 0 & 0 & 0 & 0 \\
\hline Arrears to Austria (+ increase) & 0.3 & 0.3 & 0.3 & 0.3 & 0.3 & -1.5 & 0 & 0 & 0 & 0 \\
\hline Arrears to Belgium (+ increase) & 0 & 0 & 0 & 0 & 0.2 & -0.2 & 0 & 0 & 0 & 0 \\
\hline \multirow[t]{2}{*}{ Financing gap } & 0 & 0 & 0 & 0 & 0 & 70 & 65 & 60 & 55 & 50 \\
\hline & \multicolumn{10}{|c|}{ (In percent of GDP, unless otherwise stated) } \\
\hline \multicolumn{11}{|l|}{ Memorandum items: } \\
\hline Current account (excluding official transfers) & 2.9 & 1.9 & 0.3 & 0.9 & 3.1 & 2.2 & 2.1 & 1.8 & 1.3 & 0.7 \\
\hline Current account (including official transfers) & 4.8 & 4.5 & 2.6 & 3.0 & 5.5 & 4.6 & 4.3 & 4.0 & 3.4 & 2.7 \\
\hline Total external debt $4 /$ & 49.8 & 52.7 & 52.6 & 51.0 & 47.1 & 44.5 & 43.6 & 43.1 & 42.0 & 41.4 \\
\hline Total PPG external debt & 47.0 & 50.5 & 49.3 & 48.1 & 44.4 & 41.8 & 40.8 & 40.2 & 39.1 & 38.4 \\
\hline PPG debt service $5 /$ & 7.2 & 9.4 & 9.6 & 9.7 & 9.5 & 9.5 & 9.7 & 9.4 & 9.3 & 9.4 \\
\hline Debt service 6/ & 4.2 & 4.9 & 5.0 & 4.5 & 4.6 & 4.6 & 4.8 & 4.7 & 4.6 & 4.7 \\
\hline Stock of arrears & 0.3 & 0.6 & 0.9 & 1.2 & 1.7 & 0.0 & 0.0 & 0.0 & 0.0 & 0.0 \\
\hline Gross foreign assets (end of period) & 1,423 & 1,371 & 1,462 & 1,772 & 1,870 & 1,970 & 2,158 & 2,258 & 2,320 & 2,378 \\
\hline Of which : central bank & 1,020 & 1,048 & 1,178 & 1,471 & 1,507 & 1,551 & 1,689 & 1,770 & 1,821 & 1,869 \\
\hline (In months of imports of goods and services) & 7.2 & 7.0 & 6.6 & 8.2 & 7.6 & 6.7 & 6.8 & 6.5 & 6.3 & 6.0 \\
\hline Nominal GDP (in millions of U.S. dollars) & 5,596 & 5,568 & 5,873 & 6,757 & 7,359 & 7,990 & 8,429 & 8,971 & 9,697 & 10,382 \\
\hline
\end{tabular}

Sources: Data provided bt the Nepalese authorities; and Fund staff estimates and projections.

1/ Nepal buys oil in the international market and re-exports it to India for refinery. This activity recently ceased due to deterioration in NOC finances, but are expected to resume as planned domestic oil price adjustments should improve NOC finances.

2/ Includes estimated international NGO transfers.

3/ Large other investments and errors and omissions reflect data weaknesses in capital account, unreported remittances and informal trade.

4/ Includes estimated private sector debt and short-term trade credits.

$5 /$ As a ratio of exports of goods and services (excluding reexports of oil).

6/ As a ratio of exports of goods and services (excluding re-exports of oil) and private transfer and income receipts. 
Table 5. Nepal: Medium-Term Macroeconomic Framework, 2001/02-2009/10

(In percent of GDP, unless otherwise indicated)

\begin{tabular}{|c|c|c|c|c|c|c|c|c|c|}
\hline & $2001 / 02$ & $2002 / 03$ & $2003 / 04$ & $\begin{array}{r}2004 / 05 \\
\text { Est. }\end{array}$ & \multicolumn{5}{|c|}{ Projections } \\
\hline \multicolumn{10}{|l|}{ Real sector } \\
\hline Real GDP growth (percent change) & -0.6 & 3.4 & 3.4 & 2.5 & 3.0 & 3.0 & 4.0 & 4.5 & 5.0 \\
\hline Agriculture & 2.2 & 2.5 & 3.9 & 2.8 & 2.8 & 2.8 & 3.6 & 4.4 & 5.0 \\
\hline Nonagriculture & -1.9 & 3.5 & 2.9 & 1.6 & 2.9 & 2.9 & 4.0 & 4.5 & 5.0 \\
\hline GDP deflator (percent change) & 3.4 & 4.5 & 5.0 & 4.1 & 5.0 & 5.5 & 5.0 & 5.0 & 5.0 \\
\hline \multicolumn{10}{|l|}{ Saving-investment balance } \\
\hline Gross domestic savings & 26.1 & 26.3 & 28.1 & 29.1 & 28.1 & 29.4 & 29.8 & 29.5 & 29.0 \\
\hline Public 1/ & 0.2 & 0.8 & 1.1 & 2.4 & 0.9 & 0.6 & 0.5 & 0.5 & 0.7 \\
\hline Private & 25.9 & 25.6 & 27.0 & 26.7 & 27.3 & 28.7 & 29.3 & 28.9 & 28.3 \\
\hline Gross fixed investment & 19.3 & 19.1 & 19.2 & 19.3 & 19.0 & 21.5 & 22.5 & 23.0 & 23.4 \\
\hline Public 1/ & 7.6 & 6.8 & 6.6 & 6.2 & 5.7 & 5.6 & 0.3 & 0.5 & 0.4 \\
\hline Private & 11.7 & 12.2 & 12.6 & 13.1 & 13.3 & 15.9 & 22.2 & 22.5 & 23.0 \\
\hline \multicolumn{10}{|l|}{ Fiscal sector } \\
\hline Total revenue & 11.5 & 12.3 & 12.2 & 13.0 & 13.6 & 13.6 & 13.7 & 13.7 & 13.7 \\
\hline Grants & 1.4 & 2.1 & 2.3 & 2.1 & 2.5 & 2.2 & 2.2 & 2.2 & 2.2 \\
\hline Current expenditure & 11.5 & 11.4 & 11.2 & 11.7 & 12.8 & 13.1 & 13.4 & 13.2 & 13.0 \\
\hline Capital expenditure and net lending & 5.6 & 4.6 & 4.3 & 4.3 & 4.5 & 4.8 & 5.1 & 5.3 & 5.5 \\
\hline Overall balance before grants & -5.7 & -3.7 & -3.3 & -3.0 & -3.7 & -4.3 & -4.8 & -4.8 & -4.8 \\
\hline Overall balance after grants & -4.3 & -1.6 & -1.0 & -0.9 & -1.2 & -2.1 & -2.6 & -2.6 & -2.6 \\
\hline \multicolumn{10}{|l|}{ External sector } \\
\hline Export value (percent change) $2 /$ & -18.4 & 5.6 & 14.7 & 10.4 & 10.1 & 7.6 & 8.6 & 8.9 & 9.4 \\
\hline Import value (percent change) & -15.3 & 7.5 & 15.8 & 0.3 & 11.3 & 17.6 & 8.6 & 9.3 & 8.0 \\
\hline Current account balance (excluding official transfers)/GDP & 1.9 & 0.3 & 0.9 & 3.1 & 2.2 & 2.1 & 1.8 & 1.3 & 0.7 \\
\hline Overall balance/GDP & -0.7 & 1.6 & 3.5 & 0.3 & -0.3 & 0.9 & 0.2 & 0.0 & 0.0 \\
\hline Financing gap (in million U.S. dollars) & 0 & 0 & 0 & 0 & 70 & 65 & 60 & 55 & 50 \\
\hline Change in reserves (in million U.S. dollars) & 51 & -91 & -308 & -35 & -44 & -138 & -81 & -52 & -48 \\
\hline External debt/GDP (in percent) & 52.7 & 52.6 & 51.0 & 47.1 & 44.5 & 43.6 & 43.1 & 42.0 & 41.4 \\
\hline Debt service ratio $3 /$ & 4.9 & 5.0 & 4.5 & 4.6 & 4.6 & 4.8 & 4.7 & 4.6 & 4.7 \\
\hline \multicolumn{10}{|l|}{ Monetary sector } \\
\hline Broad money (percent change) & 4.4 & 9.8 & 12.7 & 8.0 & 9.0 & $\ldots$ & $\ldots$ & $\ldots$ & $\ldots$ \\
\hline Private sector credit (percent change) & 3.9 & 14.9 & 13.9 & 13.2 & 12.6 & $\ldots$ & $\ldots$ & $\ldots$ & ... \\
\hline \multicolumn{10}{|l|}{ Memorandum item: } \\
\hline Nominal GDP (Nrs billions) & 422.8 & 456.7 & 495.6 & 529.0 & 572.0 & 621.7 & 678.8 & 744.7 & 820.9 \\
\hline
\end{tabular}

Sources: Data provided by Nepalese authorities; and staff estimates and projections.

1/ Public savings and investment estimate derived from fiscal accounts.

2/ Excluding re-exports.

3/ As a ratio of exports of goods and services (excluding reexports) and private transfers and income receipts. 
- 29 -

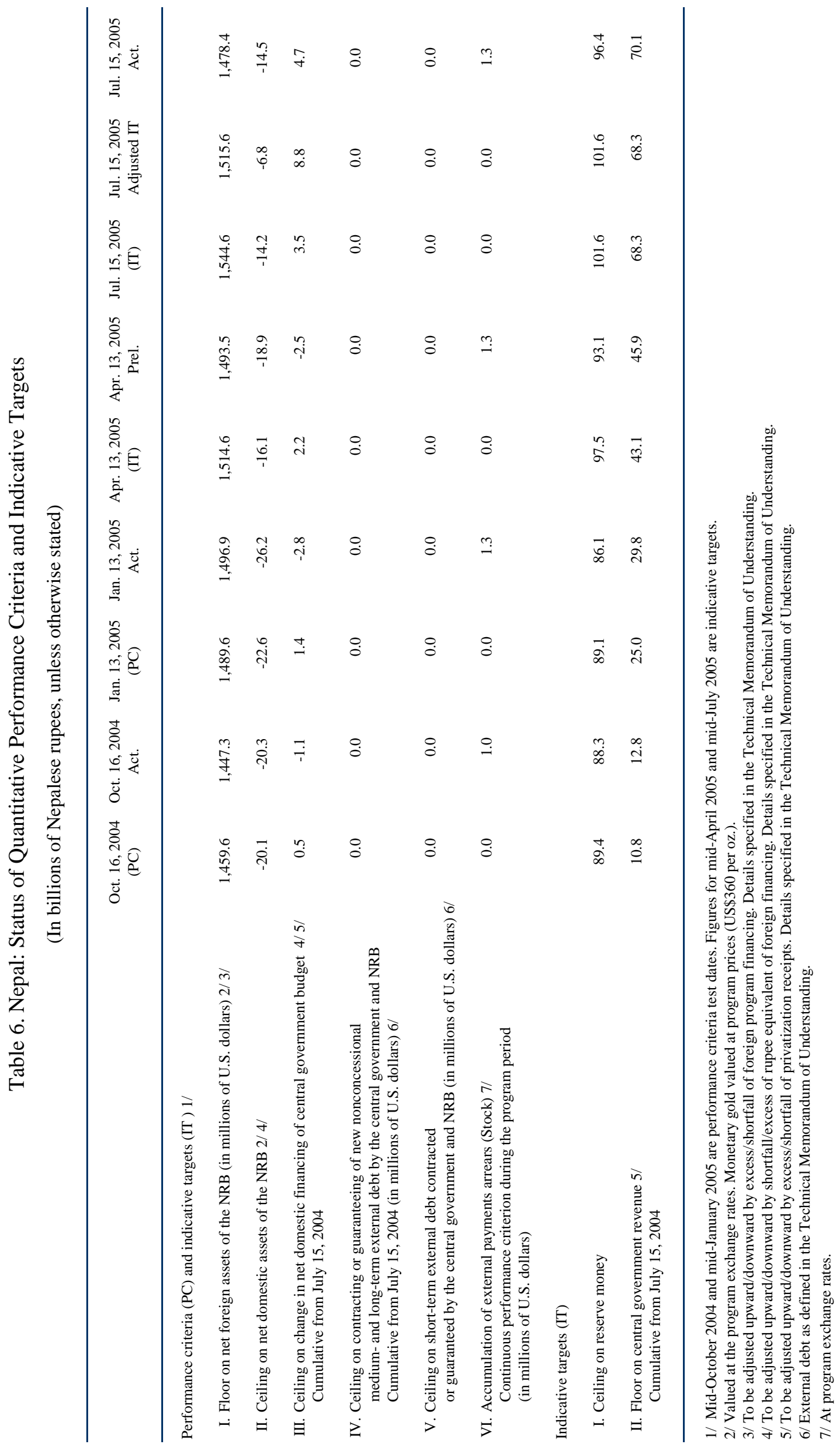




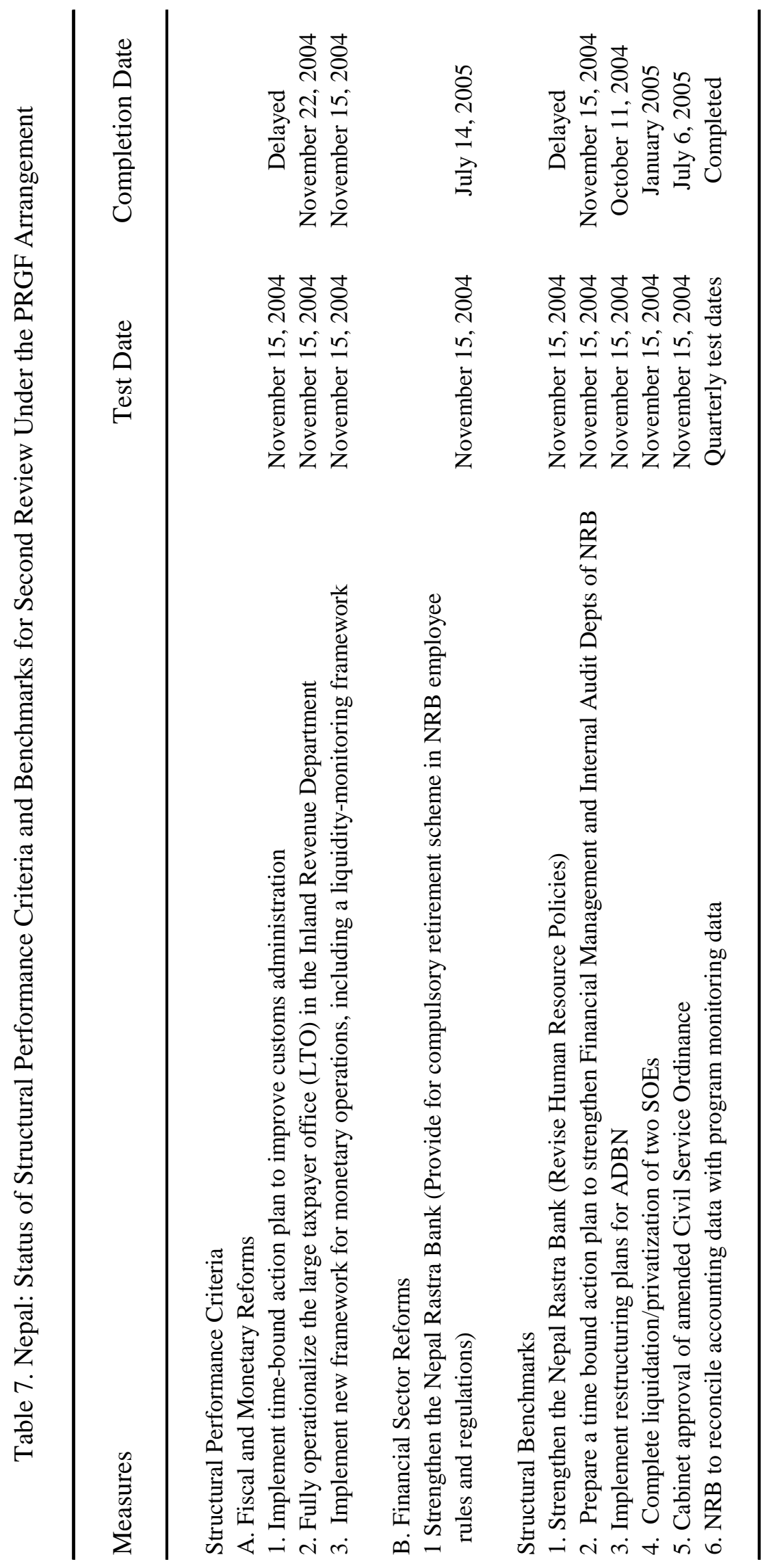




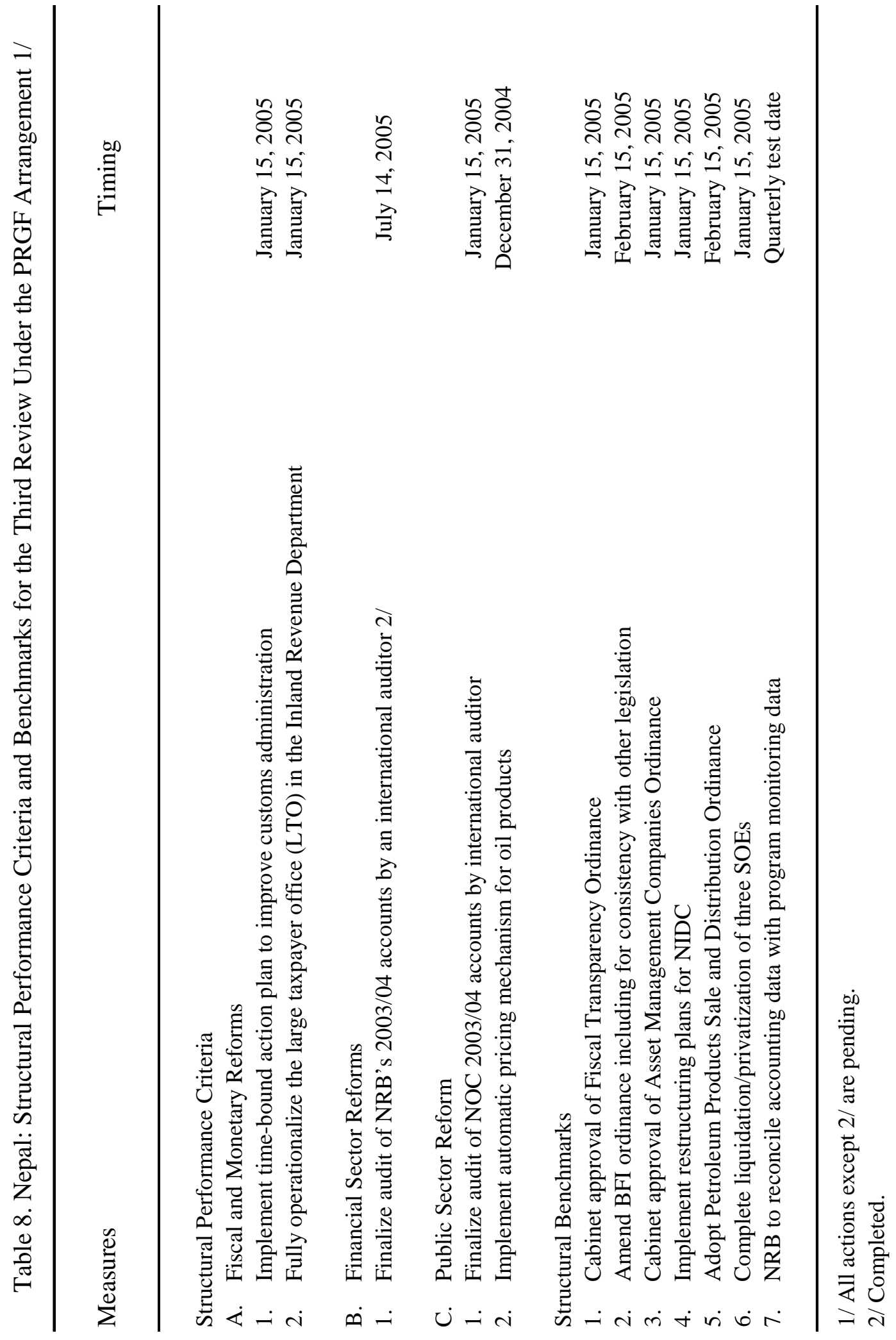


Table 9. Nepal: Millennium Development Goals, 1990-2015

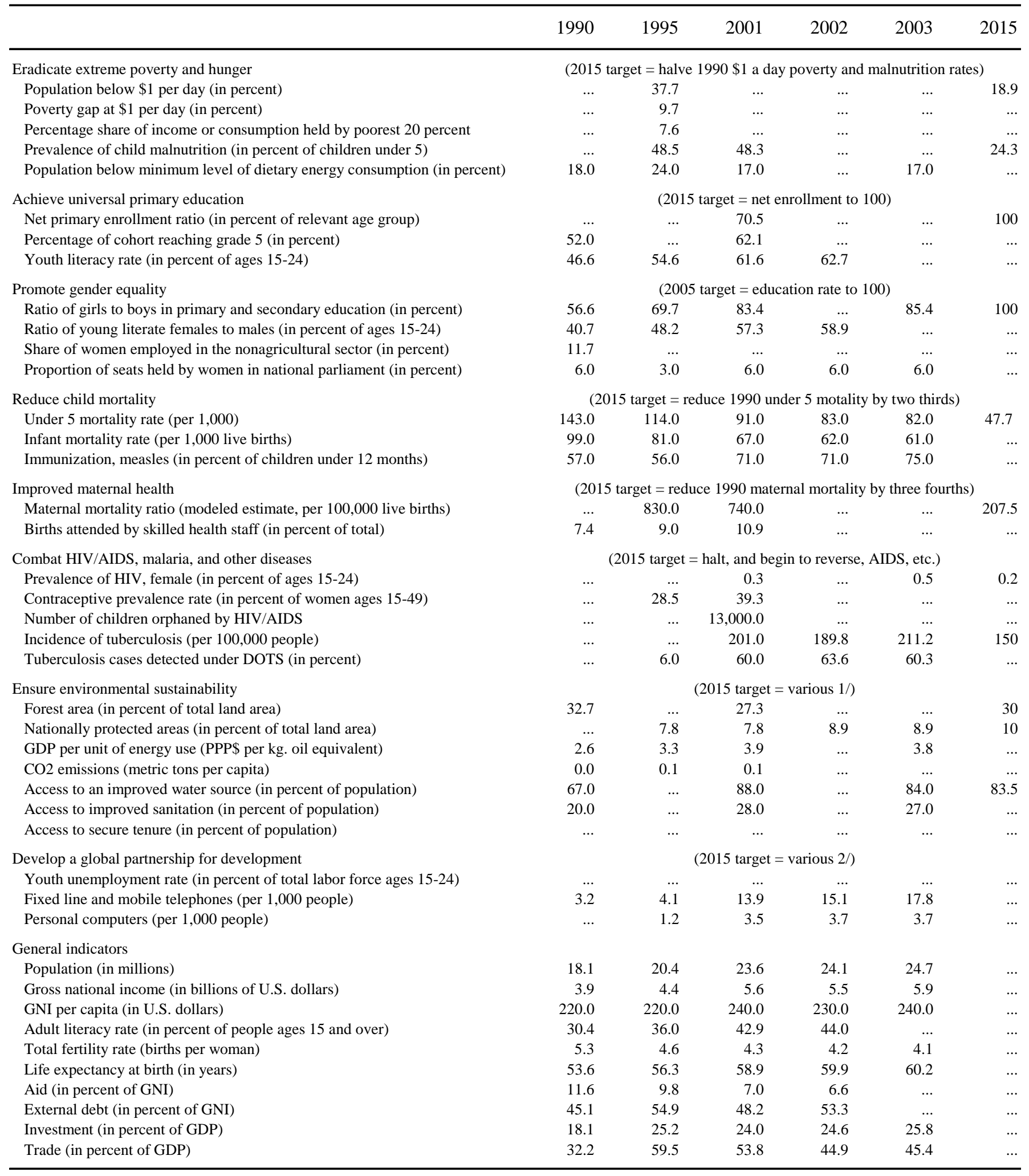

Source: World Development Indicators database.

$1 /$ Integrate the principles of sustainable development into country policies and programs and reverse the loss of environment resources. Halve, by 2015 , the proportion of people without sustainable access to safe drinking.

2/ Develop further an open, rule-based, predictable, nondiscriminatory trading and financial system. Address the special needs of the least developed countries. Address the special needs of landlocked countries and small island developing states. 


\section{Nepal-Past Main Policy Recommendations and Authorities' Responses}

\begin{tabular}{|c|c|}
\hline Recommendations & Actions \\
\hline \multicolumn{2}{|l|}{ Fiscal Policy } \\
\hline Mobilize revenue & $\begin{array}{l}\text { Revenue-to-GDP ratio increased from } 12 \frac{1}{4} \text { percent of GDP in } \\
2002 / 03 \text { to } 13 \text { percent in } 2004 / 05 \text {, reflecting increase in the VAT } \\
\text { rate in January } 2005 \text { and tax administration measures (establishment } \\
\text { of a Large Taxpayers Office and implementation of a three-year } \\
\text { customs modernization plan). }\end{array}$ \\
\hline $\begin{array}{l}\text { Improve public expenditure } \\
\text { management }\end{array}$ & $\begin{array}{l}\text { The MTEF has rationalized and prioritized the development budget. } \\
\text { Expenditure on Priority } 1 \text { projects increased; higher pro-poor } \\
\text { spending. However, capital spending remains low due to the difficult } \\
\text { security situation. }\end{array}$ \\
\hline Limit domestic borrowing & $\begin{array}{l}\text { Net domestic financing limited to an average of } 2 / 3 \text { percent of GDP } \\
\text { during 2002/03-2004/05. }\end{array}$ \\
\hline \multicolumn{2}{|l|}{ Financial Sector Policies } \\
\hline Strengthen central bank & $\begin{array}{l}\text { NRB reforms have progressed (streamlined organizational structure, } \\
\text { three VRS schemes to reduce excess staffing, outsourcing of some } \\
\text { non-core functions, and improved accounts). }\end{array}$ \\
\hline Loan recovery & $\begin{array}{l}\text { The debt recovery framework has been strengthened (blacklisting; } \\
\text { DRT). Little progress in loan recovery from large willful defaulters. }\end{array}$ \\
\hline $\begin{array}{l}\text { Restructure insolvent commercial and } \\
\text { development banks }\end{array}$ & $\begin{array}{l}\text { NBL and RBB are making profits through staff reductions and lower } \\
\text { cost of funds; however, both banks have negative net worth. ADBN } \\
\text { has been restructured; no progress with NIDC. }\end{array}$ \\
\hline \multicolumn{2}{|l|}{ Public } \\
\hline Liquidate/privatize unviable entities & Limited progress. Only three entities divested. \\
\hline $\begin{array}{l}\text { Deepen governance reforms and } \\
\text { decentralization; reduce corruption }\end{array}$ & $\begin{array}{l}\text { New Civil Service Act introduced in July } 2005 \text {. New financial } \\
\text { administration regulations were introduced in } 2003 \text {. Draft } \\
\text { Governance Ordinance prepared. Schools }(2,200) \text { and sub-health } \\
\text { posts }(1,100) \text { transferred to community management. } \\
\text { Five year anti corruption plan prepared. Increase in number of } \\
\text { successful prosecutions by the CIAA. }\end{array}$ \\
\hline \multicolumn{2}{|l|}{ Other Structural Policies } \\
\hline Regulatory Reform & $\begin{array}{l}\text { Bankruptcy, Company, Secured Transactions, Insolvency, and } \\
\text { Securities Ordinances promulgated }\end{array}$ \\
\hline Increase labor market flexibility & $\begin{array}{l}\text { Draft Labor Ordinance under discussion with provisions for more } \\
\text { flexible hiring and retrenchment. }\end{array}$ \\
\hline \multicolumn{2}{|l|}{ Statistics } \\
\hline $\begin{array}{l}\text { Strengthen data collection and } \\
\text { dissemination }\end{array}$ & $\begin{array}{l}\text { From } 2004 / 05 \text {, expenditures have been reclassified into current and } \\
\text { capital. Balance of payments data now based on } 5^{\text {th }} \text { BOP Manual. }\end{array}$ \\
\hline
\end{tabular}




\section{Nepal-Debt Sustainability Analysis}

Public debt dynamics are assessed using the Low Income Country Debt Sustainability Analysis (LIC-DSA) framework. The DSA was conducted jointly with the World Bank. Based on the external LIC-DSA, Nepal's external debt dynamics are subject to a high risk of debt distress.

\section{Low InCome Country-Debt SustainabiLity ANALYsis (LIC-DSA) ${ }^{1}$}

\section{A. Size and Composition of Public and Publicly Guaranteed (PPG) Debt}

1. Nepal's total public debt is estimated at 61 percent of GDP at end-2004, of which roughly 75 percent is external debt. External debt doubled between 1990 and 2004, reflecting budget support and project finance from multilateral institutions, mostly IDA and the AsDB. At end-2004, nominal external debt stood at around US $\$ 31 / 4$ billion, of which 90 percent was owed to multilateral institutions. By comparison, multilateral debt accounted for 29 percent of total external debt in selected Asian economies. The composition of Nepal's debt implies a high degree of concessionality, with an average grant element of close to 50 percent.
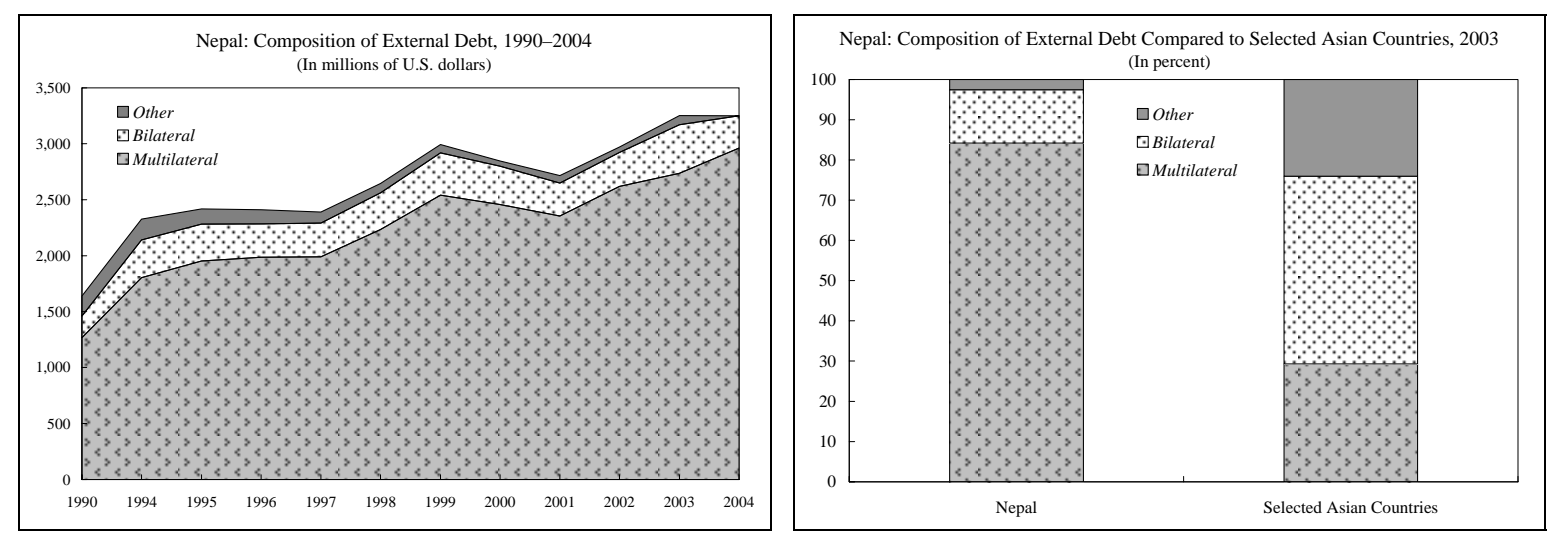

\section{B. Assumptions}

2. Baseline projections of PPG debt are based on the following key assumptions:

- Real sector: Real GDP growth is projected to rise gradually from 3 percent in 2005/06 and stabilize at 51/2 percent after 2009/10, in line with growth rates observed in the early 1990s. Inflation is projected at 5 percent. The nominal interest rate on domestic debt is expected to average 7 percent during 2005/06-20009/10, and 6 percent thereafter. The exchange rate is projected to depreciate against the dollar, in line with movements in the Indian rupee to which the Nepalese rupee is pegged.

\footnotetext{
${ }^{1}$ The LIC-DSA produces different results from calculations under the enhanced HIPC Initiative because of different methodologies.
} 
- Fiscal sector: The revenue-to-GDP ratio is projected to rise from 13 percent in 2004/05 to $133 / 4$ percent by $2007 / 08$, assuming some increase in the VAT rate and improved tax collection. The expenditure-to-GDP ratio rises from 16 percent in 2004/05 to 181/2 percent in 2007/08 as development spending picks up, and stabilizes thereafter. Growth of real primary spending averages 7 percent in 2005/06-09/10 (51/4 percent in 2010/11-2024/25).

- External sector: Exports of goods and services are projected to average 63/4 percent over the projection period. Imports of goods and services are expected to rebound in line with economic activity following the decline in 2004/05, averaging $71 / 4$ percent. The noninterest current account balance is projected to deteriorate from a surplus of 6 percent of GDP in 2004/05 to a deficit of 11/4 percent of GDP by 2024/25. Scheduled debt service on existing external debt increases from around US\$120 million in 2004/05 to US\$125 million in 2024/25. New financing is assumed to be moderate during the next three years, but rising gradually from US\$170 million in 2005/06 to US\$370 million by $2009 / 10$. The grant element of new borrowing is assumed to average around 45 percent during 2004/05-2009/10 and 40 percent thereafter.

\section{Baseline}

\section{PPG External Debt}

3. A key feature of the LIC-DSA framework is that it compares debt burden indicators to indicative policy-based thresholds. The thresholds are based on the empirical finding that low-income countries with stronger policies and institutions tend to have a higher debt carrying capacity. At end-2004, Nepal's NPV of debt-toexports ratio is estimated at 172 percent (the relevant policy-based indicative threshold is 150 percent). The ratio is projected to fall to 148 percent by $2009 / 10$ and 83 percent by $2024 / 25$. Other relevant indicators remain below the thresholds throughout the projection period.

\section{In the baseline scenario, debt burden}

\begin{tabular}{|lcc|}
\hline \multicolumn{2}{|c|}{ Nepal: Indicative External Debt Burden Indicators } \\
\hline & $\begin{array}{c}\text { Indicative } \\
\text { Thresholds 1/ }\end{array}$ & $\begin{array}{c}\text { Nepal } \\
\text { 2004/05 }\end{array}$ \\
\hline & 150 & 172 \\
NPV of debt, in percent of & 28 \\
Exports & 40 & 213 \\
GDP & 250 & \\
Revenues & 20 & 12 \\
Debt service, in percent of & 30 & \\
Exports & \\
Revenues & \\
\hline 1/ Shows indicative policy dependent thresholds under the joint IMF- \\
World Bank low-income country debt sustainability framework for a \\
medium policy performer.
\end{tabular}
ratios are projected to fall between 2004/05 and 2024/25 (Table II.1). The NPV of external public debt-to-GDP (28 percent to 15 percent) NPV of external public debt-to-exports (172 percent to 83 percent); external public debt service-to-exports ratio (10 percent to 8 percent); and external public debt service to revenues (213 percent to 109 percent). ${ }^{2}$

\footnotetext{
${ }^{2}$ Given the high concessionality of external debt, the debt service-to-exports ratio is low, and at levels similar to most HIPCs after full HIPC debt relief. The ratio reflects debt service on existing debt and debt service on projected disbursements.
} 


\section{Total Public Debt}

5. Domestic debt accounts for about 25 percent of total public debt. Under the baseline scenario, the NPV of public debt-to-GDP ratio declines from 44 percent at end-2004/05 to 30 percent by 2024/25 (Table II.4; Figure II.2). Over the same period, the NPV of public debt-to-revenue ratio falls from 292 percent to 190 percent, and the public debt service-to revenue ratio decreases from 23 percent to 16 percent.

\section{Sensitivity Analysis}

\section{Stress tests suggest that Nepal's debt profile is susceptible to shocks.}

- Total public debt: Following an extreme shock-a one-time 30 percent real depreciation in 2005/06 which leads to the highest level of NPV of debt-to-GDP 10 years after the shock-the NPV ratio peaks at around 54 percent in 2005/06 and falls to about 33 percent in $2024 / 25$. The debt service to revenue ratio peaks in $2008 / 09$ at 28 percent converging to the baseline level of 16 percent in 2024/25.

- External debt: Following an export shock — defined as export value growth at historical levels minus one standard deviation in the first two years of the shock-the NPV of debtto-exports ratio increases significantly, peaking at 333 percent in the last year of the shock. The debt service-to-exports ratio peaks at 19 percent in 2014/15. These results are driven by Nepal's recent volatile export performance. The combined shocks scenario has a similar effect, primarily based on the export component of the shock. Under a low growth scenario ( 3 percent), the NPV of external debt-to-GDP ratio would be higher by 7 percent of GDP by $2024 / 25$ relative to the baseline.

\section{E. Staff Assessment}

7. Based on the LIC-DSA, staffs conclude that Nepal's external debt dynamics are subject to a high risk of distress. The sensitivity analyses underscore the need to implement sound macroeconomic policies and reforms, including toward achieving higher export growth, while maintaining efforts to raise revenue. Those factors combined with foreign financing at favorable terms - preferably through grants-would help Nepal make progress toward achieving its MDG targets while containing risks to debt sustainability.

\section{ENHANCED HIPC AND MULTILATERAL DEBT RELIEF (MDR) INITIATIVES}

8. Nepal was recently deemed to be potentially eligible - on a preliminary basis - for HIPC relief under the extended sunset clause. This determination was based on an estimated end-2004 NPV of debt-to-exports ratio (around 200 percent after traditional debt relief; the enhanced HIPC threshold is 150 percent). If Nepal's eligibility is confirmed in early 2006, it could receive relief under the enhanced HIPC Initiative and MDRI. 
Figure II.1. Nepal: Indicators of Public and Publicly Guaranteed External Debt Under Alternative Scenarios, 2005-2025

(In percent)
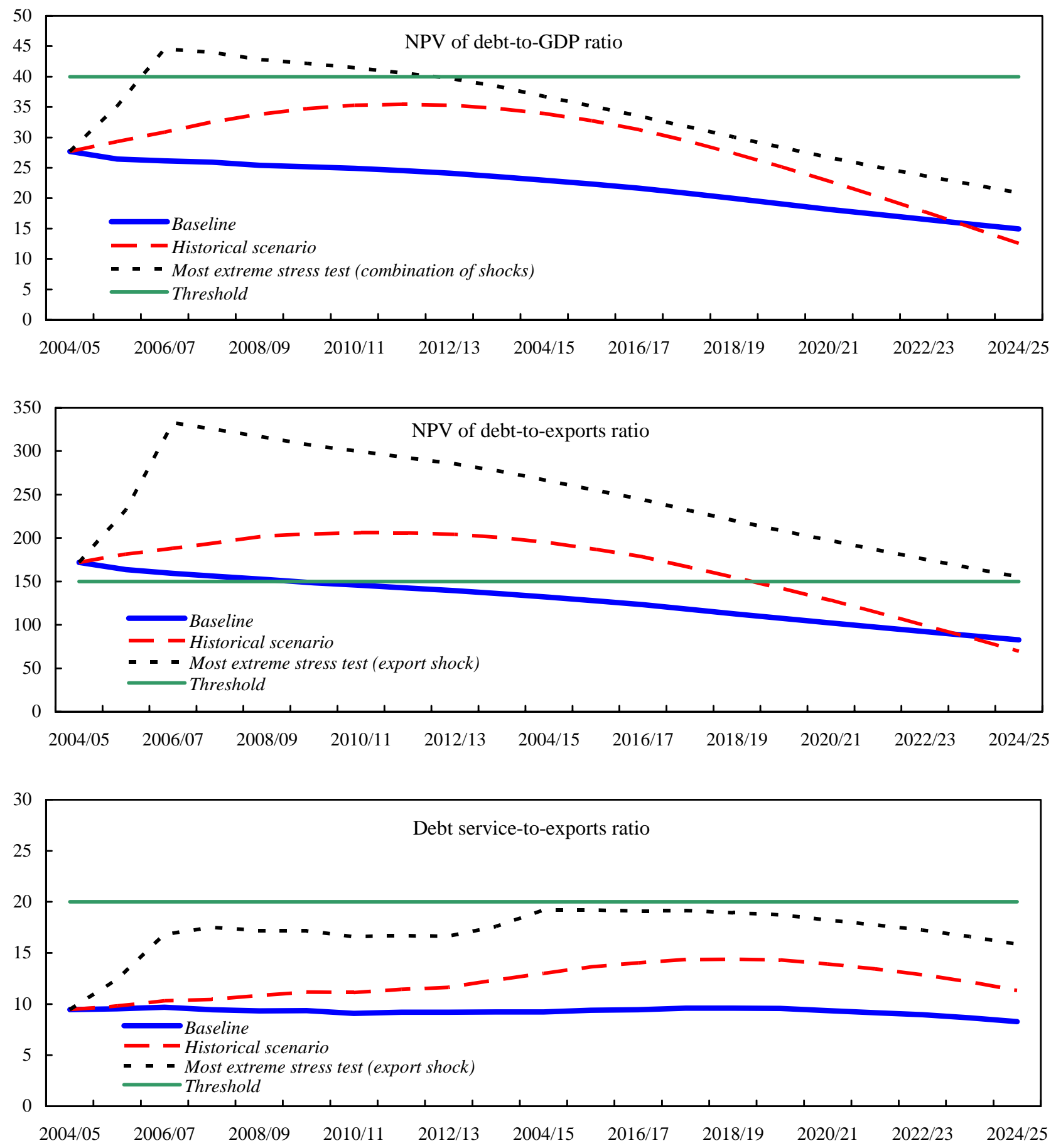

Source: Staff projections and simulations. 
Figure II.2. Nepal: Indicators of Public Debt Under Alternative Scenarios, 2005-2025 1/ 2/ (In percent)
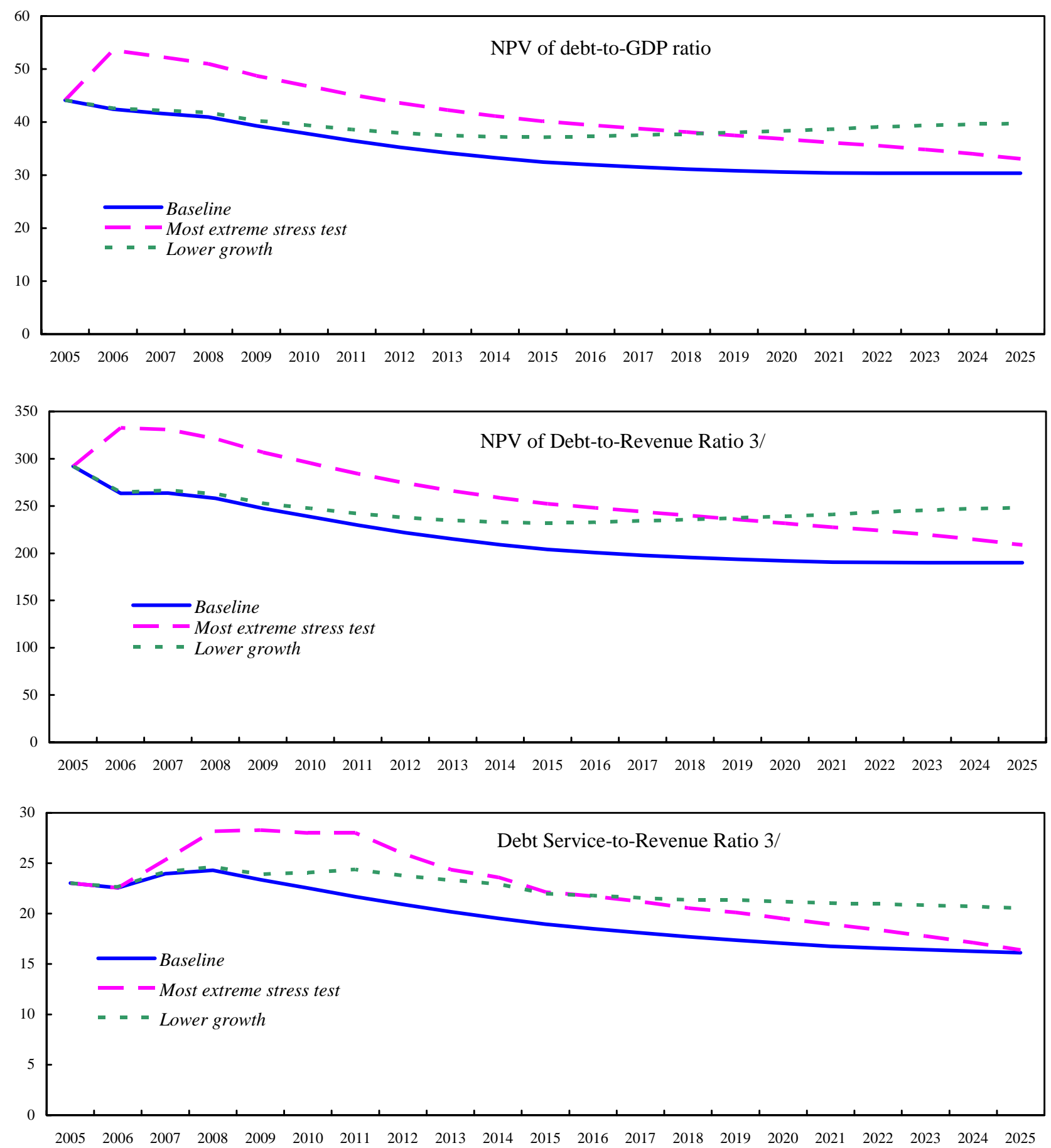

Source: Staff projections and simulations.

1/ Most extreme stress test is test that yields highest ratio in 2015.

2/ 2005 refers to fiscal year 2004/05.

3 / Revenue including grants. 


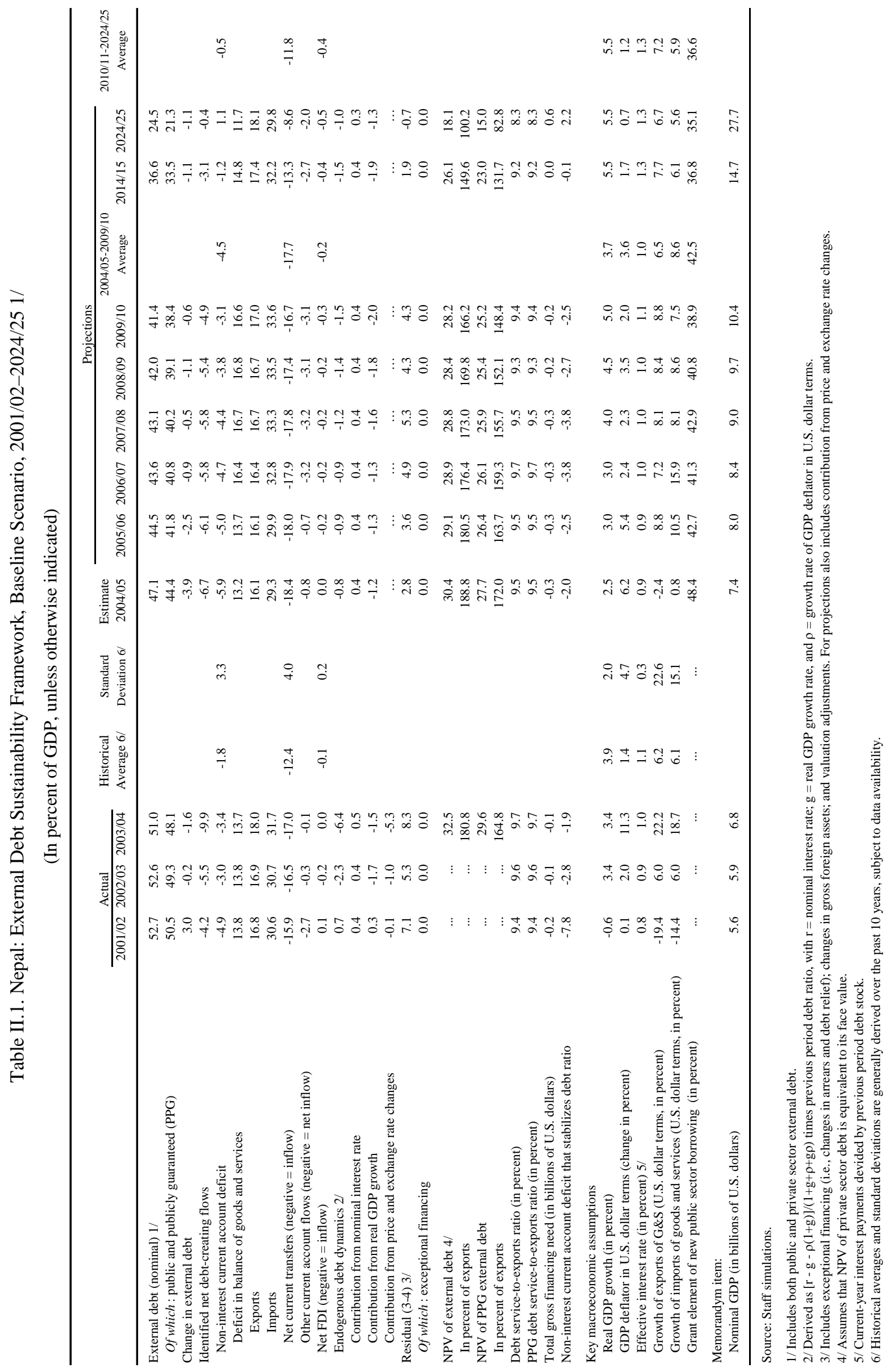


Table II.2. Nepal: Sensitivity Analyses for Key Indicators of Public and Publicly Guaranteed External Debt, 2004/05-2024/25 (In percent)

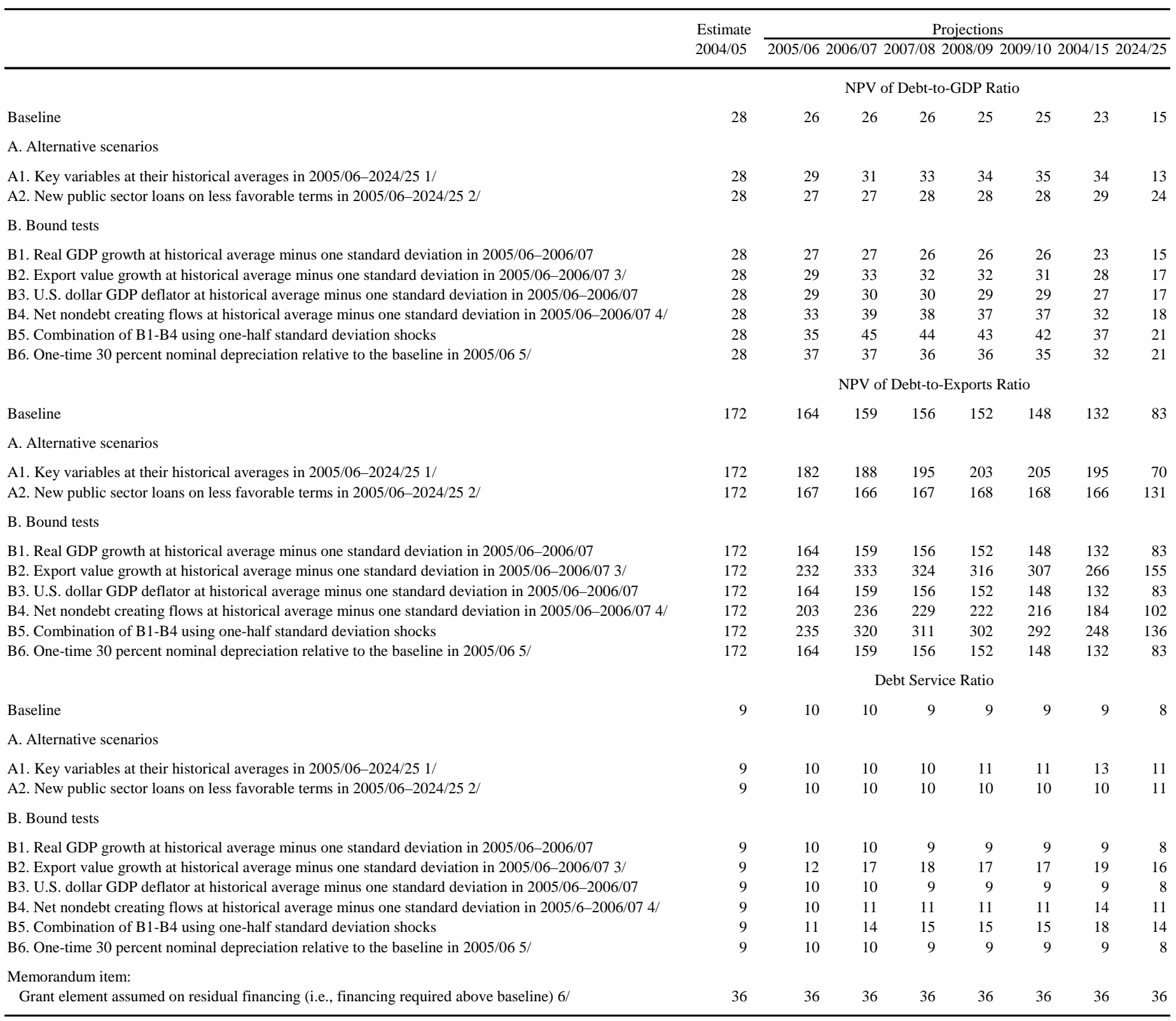

Source: Staff projections and simulations.

1/ Variables include real GDP growth, growth of GDP deflator (in U.S. dollar terms), non-interest current account in percent of GDP, and nondebt creating flows.

2/ Assumes that the interest rate on new borrowing is by 2 percentage points higher than in the baseline., while grace and maturity periods are the same as in the baseline.

3/ Exports values are assumed to remain permanently at the lower level, but the current account as a share of GDP is assumed to return to its baseline level after the shock (implicitly assuming an offsetting adjustment in import levels).

4/ Includes official and private transfers and FDI.

5/ Depreciation is defined as percentage decline in dollar/local currency rate, such that it never exceeds 100 percent.

6/ Applies to all stress scenarios except for A2 (less favorable financing) in which the terms on all new financing are as specified in footnote 2. 


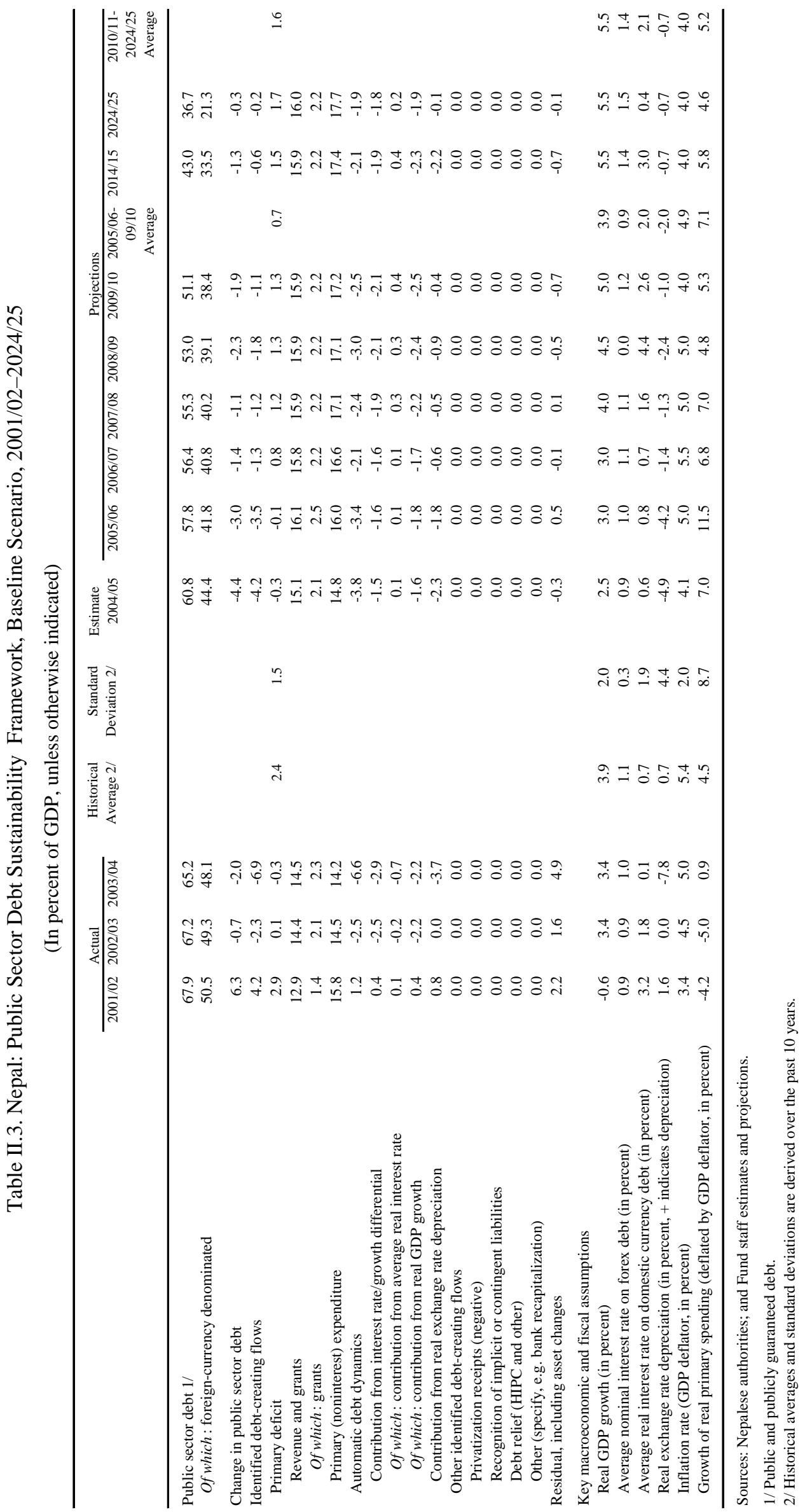


Table II.4. Nepal: Sensitivity Analysis for Key Indicators of Public Debt, 2005-2025

\begin{tabular}{|c|c|c|c|c|c|c|c|c|c|c|c|c|}
\hline & \multirow{2}{*}{$\begin{array}{r}\text { Estimate } \\
2005\end{array}$} & \multicolumn{11}{|c|}{ Projections } \\
\hline & & 2006 & 2007 & 2008 & 2009 & 2010 & 2011 & 2012 & 2013 & 2014 & 2015 & 2025 \\
\hline \multicolumn{13}{|c|}{ NPV of Debt-to-GDP Ratio } \\
\hline Baseline & 44 & 42 & 42 & 41 & 39 & 38 & 36 & 35 & 34 & 33 & 32 & 30 \\
\hline \multicolumn{13}{|l|}{ A. Alternative scenarios } \\
\hline A1. Real GDP growth and primary balance are at historical averages & 44 & 44 & 45 & 45 & 44 & 44 & 44 & 44 & 44 & 44 & 44 & 44 \\
\hline A2. Primary balance is unchanged from 2004 & 44 & 42 & 40 & 38 & 35 & 33 & 30 & 27 & 25 & 23 & 21 & 6 \\
\hline A3. Permanently lower GDP growth $1 /$ & 44 & 43 & 42 & 42 & 40 & 39 & 39 & 38 & 38 & 37 & 37 & 40 \\
\hline \multicolumn{13}{|l|}{ B. Bound tests } \\
\hline B1. Real GDP growth is at historical average minus one standard deviations in $2006 / 07$ & 44 & 43 & 43 & 42 & 41 & 40 & 39 & 38 & 37 & 36 & 36 & 32 \\
\hline B2. Primary balance is at historical average minus one standard deviations in $2006 / 07$ & 44 & 46 & 48 & 47 & 45 & 44 & 42 & 41 & 40 & 39 & 38 & 31 \\
\hline B3. Combination of B1-B2 using one half standard deviation shocks & 44 & 45 & 47 & 46 & 44 & 42 & 41 & 40 & 39 & 38 & 37 & 30 \\
\hline B4. One-time 30 percent real depreciation in 2006 & 44 & 54 & 52 & 51 & 49 & 47 & 45 & 44 & 42 & 41 & 40 & 33 \\
\hline B5. 10 percent of GDP increase in other debt-creating flows in 2006 & 44 & 42 & 42 & 41 & 39 & 38 & 37 & 36 & 35 & 34 & 33 & 32 \\
\hline \multicolumn{13}{|c|}{ NPV of Debt-to-Revenue Ratio 2/ } \\
\hline Baseline & 292 & 263 & 264 & 258 & 247 & 239 & 230 & 222 & 215 & 209 & 204 & 190 \\
\hline \multicolumn{13}{|l|}{ A. Alternative scenarios } \\
\hline A1. Real GDP growth and primary balance are at historical averages & 292 & 275 & 282 & 283 & 280 & 280 & 279 & 278 & 276 & 275 & 273 & 269 \\
\hline A2. Primary balance is unchanged from 2004 & 292 & 262 & 256 & 242 & 221 & 205 & 188 & 173 & 158 & 144 & 131 & 40 \\
\hline A3. Permanently lower GDP growth 1/ & 292 & 265 & 266 & 263 & 253 & 248 & 242 & 238 & 235 & 233 & 232 & 248 \\
\hline \multicolumn{13}{|l|}{ B. Bound tests } \\
\hline B1. Real GDP growth is at historical average minus one standard deviations in $2006 / 07$ & 292 & 266 & 271 & 267 & 256 & 249 & 242 & 237 & 232 & 228 & 224 & 201 \\
\hline B2. Primary balance is at historical average minus one standard deviations in $2006 / 07$ & 292 & 285 & 303 & 297 & 284 & 275 & 266 & 258 & 251 & 244 & 239 & 198 \\
\hline B3. Combination of B1-B2 using one half standard deviation shocks & 292 & 281 & 295 & 289 & 276 & 267 & 258 & 250 & 244 & 238 & 232 & 192 \\
\hline B4. One-time 30 percent real depreciation in 2006 & 292 & 333 & 331 & 321 & 307 & 295 & 284 & 274 & 266 & 259 & 252 & 209 \\
\hline B5. 10 percent of GDP increase in other debt-creating flows in 2006 & 292 & 263 & 264 & 258 & 248 & 241 & 232 & 225 & 219 & 214 & 209 & 200 \\
\hline \multicolumn{13}{|c|}{ Debt Service-to-Revenue Ratio 2/ } \\
\hline Baseline & 23 & 23 & 24 & 24 & 23 & 23 & 22 & 21 & 20 & 20 & 19 & 16 \\
\hline \multicolumn{13}{|l|}{ A. Alternative scenarios } \\
\hline A1. Real GDP growth and primary balance are at historical averages & 23 & 22 & 24 & 26 & 26 & 26 & 26 & 24 & 22 & 21 & 19 & 16 \\
\hline A2. Primary balance is unchanged from 2004 & 23 & 23 & 24 & 24 & 22 & 21 & 20 & 18 & 16 & 15 & 13 & 3 \\
\hline A3. Permanently lower GDP growth 1/ & 23 & 23 & 24 & 25 & 24 & 24 & 24 & 24 & 23 & 23 & 22 & 21 \\
\hline \multicolumn{13}{|l|}{ B. Bound tests } \\
\hline B1. Real GDP growth is at historical average minus one standard deviations in 2006/07 & 23 & 23 & 24 & 25 & 24 & 24 & 25 & 24 & 23 & 23 & 21 & 17 \\
\hline B2. Primary balance is at historical average minus one standard deviations in $2006 / 07$ & 23 & 23 & 25 & 28 & 28 & 28 & 28 & 26 & 24 & 24 & 22 & 16 \\
\hline B3. Combination of B1-B2 using one half standard deviation shocks & 23 & 23 & 25 & 27 & 27 & 27 & 27 & 25 & 24 & 23 & 22 & 16 \\
\hline B4. One-time 30 percent real depreciation in 2006 & 23 & 23 & 25 & 26 & 27 & 25 & 25 & 25 & 24 & 23 & 22 & 16 \\
\hline B5. 10 percent of GDP increase in other debt-creating flows in 2006 & 23 & 23 & 24 & 24 & 26 & 23 & 24 & 23 & 22 & 21 & 20 & 16 \\
\hline
\end{tabular}

Sources: Country authorities; and Fund staff estimates and projections.

1/ Assumes that real GDP growth is at baseline minus one standard deviation divided by the square root of 20 (i.e., the length of the projection period).

2/ Revenues are defined inclusive of grants. 


\section{Nepal-Fund Relations}

(As of November 30, 2005)

I. Membership Status: Joined 9/06/61; Article VIII, Sections 2, 3, and 4 in May 1994

II. General Resources Account:

Quota

Fund holdings of currency

Reserve position in Fund

III. SDR Department:

Net cumulative allocation

Holdings

IV. Outstanding Purchases and Loans:

PRGF arrangements
SDR Million

71.30

71.31

0.00

\section{SDR Million}

8.10

6.18

SDR Million
14.26

Amount

Approved (SDR Million)

Type

$$
\begin{aligned}
& \text { Approval } \\
& \text { Date }
\end{aligned}
$$

PRGF

PRGF

SAF
$11 / 19 / 03$

$10 / 05 / 92$

$10 / 14 / 87$

\section{Expiration \\ Date}

$11 / 18 / 06$

$10 / 04 / 95$

$10 / 13 / 90$
49.91

33.57

26.11
\% Quota

100.00

100.02

0.00

\section{\% Allocation \\ 100.0 \\ 76.28}

\% Quota
20.00

VI. Projected Obligations to Fund (in millions of SDRs; based on existing use of resources and present holdings of SDRs):

\begin{tabular}{lllll} 
Forthcoming \\
\hline 2005 & 2006 & 2007 & 2008 & 2009
\end{tabular}

Principal

Charges/Interest

Total

$\begin{array}{lllll}\underline{0.04} & \underline{0.13} & \underline{0.13} & \underline{0.13} & \underline{0.13} \\ 0.04 & 0.13 & 0.13 & 0.13 & 1.55\end{array}$

\section{Exchange Rate Arrangement}

In February 1993, Nepal unified its exchange rate and eliminated the multiple currency practice associated with the previous dual exchange rate arrangement. In October 1997, the exchange arrangement of Nepal was reclassified as that pegged to a single currency unit from pegged to a currency composite. Currently, all merchandise imports (except for a few goods restricted for security or related reasons) are freely available through an open general license system, with foreign exchange provided through the banking system at the market exchange rate. Nepal's exchange system is free of restrictions on the making of payments and transfers for current 
international transactions. As of December 5, 2005, the exchange rate for the Nepalese rupee (Nr) was US\$1=Nrs 74.6.

\section{Safeguards Assessments}

A safeguards assessment of the NRB was completed on September 3, 2002. The assessment concluded that substantial risks may exist in the area of external and internal audits, and the internal control system of the NRB. Staff findings and recommendations were reported in IMF Country Report No. 02/205. Implementation of the measures by the NRB needs to be monitored by staff. Based on these findings, international audits of NRB 2002/03 and 2003/04 accounts were included in program conditionality.

\section{2003 Article IV Consultation}

The Executive Board discussed the staff report for the 2003 Article IV consultation (IMF Country Report No. 03/283) on August 22, 2003. Nepal is currently on a 24-month consultation cycle, subject to the provisions of the July 15, 2002 decision on consultation cycles

(Decision No. 129794-(02/76) as amended).

X. Technical Assistance Since 2001

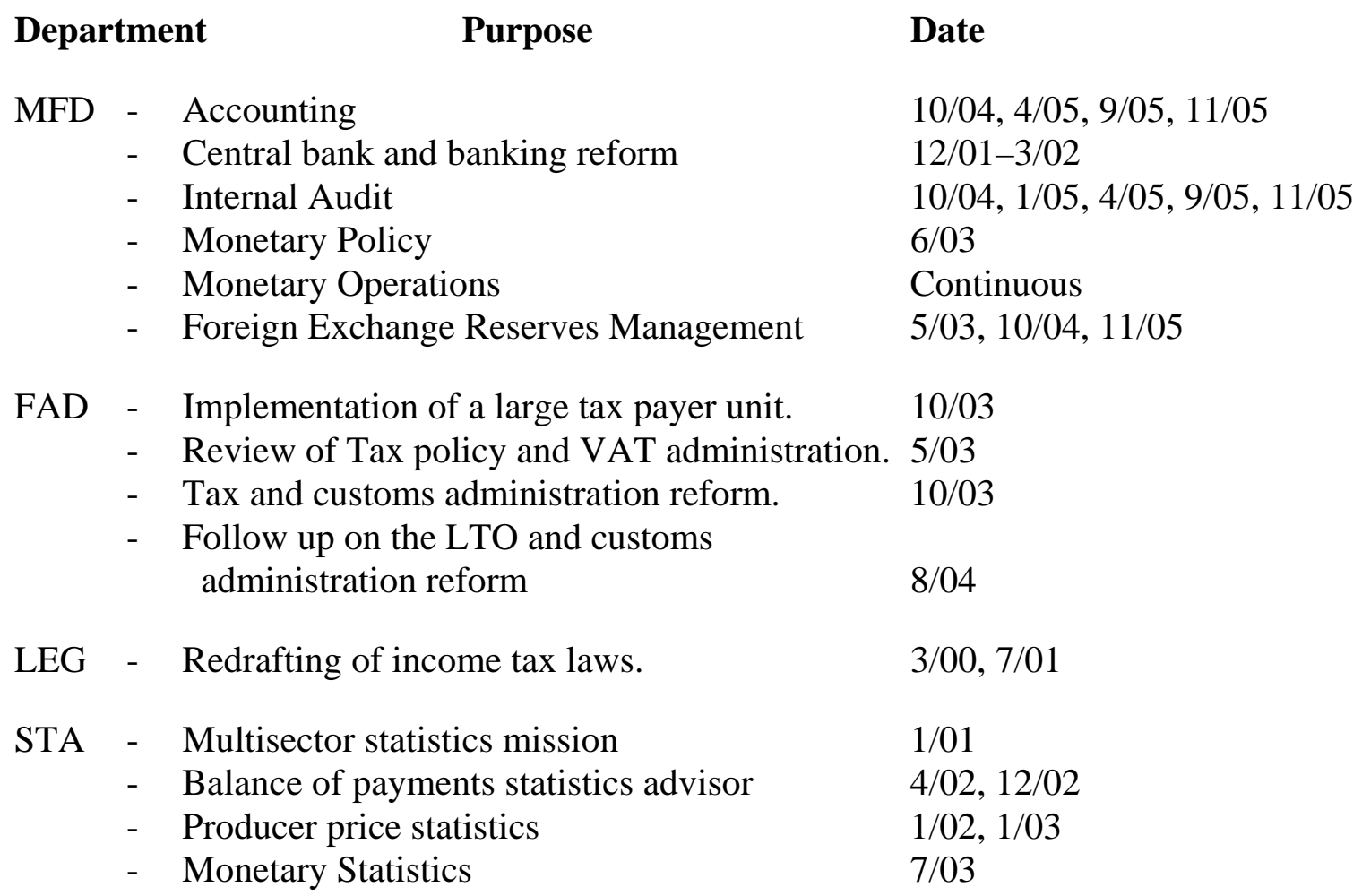

\section{Resident Representative/Advisor}

Mr. Sukhwinder Singh has been the resident representative since October 2002. 


\section{Nepal-Relations with the World Bank Group}

(As of December 28, 2005)

\section{A. Partnership in Nepal's Development Strategy}

Since the late 1990s, Nepal's poverty reduction agenda has been held back by formidable challenges - the persistent political instability, the escalation of the Maoist insurgency, and the global economic slowdown. Amidst the turbulence, a group of committed, reform-minded Government officials and technocrats began implementing reforms in earnest in late 2001. These initiatives formed the basis for the first Immediate Action Plan (IAP) adopted by the Government in June 2002. As a result, reform efforts intensified in a number of areas, including the financial sector, public expenditures, the fight against corruption, infrastructure regulatory environment and decentralized delivery of public services.

The reform group had been building on the successful experience with the IAP in moving the reform process forward. In developing the 2003 Poverty Reduction Strategy (PRS), the scope of the reforms was broadened and a more integrated approach within a medium-term perspective was adopted. The PRS spells out specific development targets, foremost among which is the reduction of the overall poverty ratio from about 40 percent to 30 percent by the end of FY07. The strategy revolves around four key pillars: (i) achieving sustainable and broad-based economic growth with an emphasis on the rural economy; (ii) accelerating human development through improved delivery of basic social services and economic infrastructure; (iii) ensuring social and economic inclusion of the poor, marginalized groups and less developed regions; and (iv) vigorously pursuing good governance to achieve better development results and ensure social and economic justice.

The Poverty Reduction Strategy Paper (PRSP)—formally sent to the World Bank and the IMF in July 2003 — was discussed by the Boards in November 2003 following a joint staff assessment carried out by the two institutions. Moreover, the Bank and the IMF have supported Nepal to implement the IAP/PRS. The IMF is in the lead in assisting Nepal maintain macroeconomic stability. An agreed medium-term macroeconomic framework forms the basis for the three-year Poverty Reduction and Growth Facility (PRGF) approved by the IMF Board in November 2003 in support of the reform program. The PRGF focuses on medium-term fiscal consolidation as well as structural reforms related to the financial system, public sector management, and government revenue mobilization.

In implementing the 2003 Country Assistance Strategy (CAS) considered by the Board at the same time as the PRSP, the Bank is in the lead with the policy dialogue in the structural and institutional areas. The Bank has been engaged in intensive dialogue in the formulation of reform efforts towards rationalization of public expenditures, establishment of a framework conducive to private sector growth, decentralization for better service delivery, targeted assistance to vulnerable groups and improving governance. To support these measures, the Bank's Board approved the first Poverty Reduction Support Credit I (PRSC I) in November 2003. The Bank's future engagement is complemented by a program of financial assistance articulated in the CAS, but currently that assistance is being reviewed. In that the Bank's lending is closely linked to policy performance and reform implementation, there are currently serious concerns about the slow pace of reform implementation over the last year. 


\section{B. IMF-World Bank Collaboration in Specific Areas}

\section{Areas in which the Bank leads and there is no direct IMF involvement}

The areas in which the Bank leads the policy dialogue and there is no direct IMF involvement are the social sectors, infrastructure, and environment. In the social sphere, the Bank continues to assist Nepal in poverty analysis as a follow-on to the 1999 study, Poverty at the Turn of the Twenty-First Century. The Bank provided technical assistance (TA) in conducting the Nepal Living Standards Survey II (NLSS II) during 2003/04 aimed at updating household level information on trends in consumption, poverty, and their determinants. The Bank's TA also seeks to strengthen Nepal's capacity to undertake regular household surveys that will facilitate poverty comparisons over time and to conduct social impact analyses. The NLSS II has been a key input into the two annual PRS progress reports, as well as the Bank's planned comprehensive Poverty Report (FY06).

In education, the Bank and numerous other donors are actively supporting Nepal's well-formulated ten-year primary education reform program. IDA along with Denmark, Finland, Norway and the UK have established a joint financing arrangement whereby donor funds are pooled with public sector budgetary resources to support the program. IDA support is in the form of financing for the Education for All project under a Sector Wide Approach (SWAp) approved in August 2004.

The Bank has encouraged Nepal's decentralization efforts towards more efficient delivery of public services. It has played a pivotal role in supporting the transfer of public schools to community management. The Bank's dialogue is accompanied by financing in the form of the Community School Support Learning and Innovation Loan (LIL) to improve accountability of primary schools, build capacity of communities to manage schools and develop the roles of teachers, local officials and education offices within the devolved framework.

In health, the Bank has been supporting the devolution of sub-health posts to local communities, and the development of a sector-wide reform strategy. A Health Sector Operation - approved by the Board in September 2004 - supports the sector-wide program. Key reform priorities include addressing the problems of inadequate financing and inefficient public spending, weak institutional capacity and over-centralized planning and management, weak delivery mechanisms and inequitable access to services.

To help generate broad-based growth, the Bank supports investments in key infrastructure sectors by financing projects in Road Maintenance and Development, Rural Access Improvement and Decentralization, Power Development, and Telecommunications Sector Reform. At the same time, project finance is supporting decentralization to improve service delivery in most of these sectors by promoting grassroots-driven, bottom-up planning and community-based management. The Road Maintenance and Development Project supports key sectoral policy reforms by establishing a Roads Board and Road Fund to assure a stable source of funding for maintenance expenditures, while also promoting motorable access to isolated regions. The recently approved Rural Access Improvement and Decentralization Project will help to improve governance and service delivery for rural infrastructure, while at 
the same time promoting agricultural and rural economic growth, and generating employment through direct project investments in rural transport infrastructure.

The Power Development Project will help with the development of the country's hydropower potential to meet electricity demand, improve access of rural areas to electricity services and promote private sector participation. The Telecommunications Sector Reform Project supports sectoral policy reforms in addition to the provision of greater rural access to telecommunications services through the introduction of a private operator.

While Bank financing of investment and sector operations also supports social inclusion, the Bank assisted in the design, implementation and evaluation of a Poverty Alleviation Fund (PAF) instrument. The PAF channels resources to grassroots levels, creating a mechanism for continuity and coordination of donor programs for poverty reduction. Bank financing for the PAF project approved in FY04 is supporting the fund's implementation. In addition, the Bank is assisting Nepal in gaining a better understanding of the institutional underpinnings of caste, ethnic and gender-based social and economic exclusion and how these affect poverty outcomes and the options for policy and institutional reform through a recently completed Social and Gender Analysis. The Bank along with ILO and UNICEF will continue to build on the work of the 2003 Nepal Understanding Child Labor Project towards a comprehensive framework for addressing child labor issues.

In responding to environmental management, Bank assistance is focused on helping Nepal articulate an effective strategy for environmental conservation, management and capacity building. A Country Environmental Analysis is being carried out and will be completed in FY07.

\section{Areas in which the Bank leads and its analysis serves as input into the IMF program}

The Bank takes the lead in assisting Nepal with public expenditure analysis. The Bank's FY00 Public Expenditure Review (PER) provided analytical support for developing the strategy on public expenditure reform. Together with the United Kingdom Department for International Development (DfID), the Bank's intensive dialogue and technical assistance have been supporting the reforms, including the development of a credible Medium Term Expenditure Framework (MTEF). In FY03, this framework was applied to the prioritization of the development budget to ensure efficient budget allocations for FY04 priority projects, and efforts are underway to apply it to all expenditures in the future. As Nepal implements its PRS, the MTEF will help the public sector translate the PRS priorities into fiscal realities.

Public expenditure analysis remains an integral part of the Bank's analytical and advisory (AAA) work program. An ongoing PER is focusing on evaluating the implementation of the MTEF. In addition, the Public Finance Management (PFM) Review to be completed in FY07 partly consists of a PER that will examine the fiscal space for development activities and cross-sectoral allocation of public spending and service delivery.

To complement the economic analysis, studies on the public sector's framework for financial accountability and procurement - the Country Procurement Assessment Review (CPAR) and the Country Financial Accountability Assessment (CFAA) — were conducted jointly by the 
Bank and the Government. Additionally, in response to technical assistance and training needs on public expenditure management, decentralization and enhancement of financial accountability, the Bank is providing support through Institutional Development Fund (IDF) grants or the Bank's budget.

On the financing side, should there be a reinvigoration of the reform process, future Bank support could include subsequent PRSCs in line with the programmatic approach articulated in the 2003 CAS. PRSC I supported the implementation of the PRS by expanding the fiscal space to increase priority spending, refining the MTEF, improving the efficiency of key parastatals, and removing impediments to broad-based growth (through improvements in the effectiveness of irrigation, rural transport and power sector investments and reforms of the labor market, the financial system and the telecommunications sector). To assist in the reform effort, the recently approved Economic Reform Technical Assistance Project can provide technical assistance to any or all of the PRS pillars. The Bank's AAA program places emphasis on the need to address the challenges and bottlenecks to broad-based growth. In addition to the Development Policy Review, key studies on rural sector development and labor are envisioned to help prioritize future policy reforms.

With respect to governance, in implementing the 1998 CAS and the new strategy, the Bank has consistently and firmly assisted Nepal in addressing its fundamental constraint to development-poor governance. The Bank's strong stance manifested in the restricted new lending during FY99-FY02 - albeit accompanied by intensive dialogue-may have provided some impetus to the wave of recent reforms. The public expenditure reform program which has benefited from the Bank's analytical work and policy dialogue is facing up to the challenge of improving not only efficiency but also governance. The program includes measures to fight corruption, ensure civil service accountability and enhance transparency of public financial management and procurement framework. Bank support on decentralization includes analytical assistance on the fiscal decentralization framework and promotion of the expanded roles of local bodies. Following the completion of the CPAR and CFAA, IDF grants are providing the means for strengthening relevant public sector institutions and implementing main policy recommendations. The FY07 PFM Review will also comprise a CPAR and a CFAA aimed at assessing the efficiency of public finance management practices for delivering value for money and accountability.

\section{Areas of shared responsibility}

The Bank and the IMF, in conjunction with other external development partners, provided assistance in the preparation of the PRS and carried out a Joint Staff Assessment (JSA). In addressing the PRS pillar on achieving good governance, the Bank and the IMF are assisting in the area of civil service reform through policy dialogue and technical assistance towards ensuring an autonomous and professional civil service as well as fiscal sustainability. The Bank has proposed to carry out a policy note (FY06) on the delineation of responsibilities between ministers and civil servants with a view to supporting better human resource management.

The Bank and the IMF are partners in providing analytical support to the Government on international trade, which is key to attaining broad-based growth. The Bank leads the work 
with a Trade and Competitiveness Study (FY03) which helped identify major constraints to Nepal's further integration into the multilateral trading system in a manner that is supportive of the PRS. The IMF contributed to the study by assessing macroeconomic policy and its potential impact on trade performance. In turn, the study is helping the IMF design its technical assistance program on tax policy, including import tariffs taking into account Nepal's WTO accession.

Financial sector reform is a prerequisite for successful implementation of the IAP and PRS. Since the mismanagement of key financial institutions was a major element of poor governance, the progress on financial sector reform has been the litmus test of political commitment to governance reform. The Bank and the IMF are helping to strengthen the Central Bank's authority and regulatory capacity, improve the financial health of the two largest banks, restructure the state banks and upgrade the legislative and institutional framework for the financial sector. The Bank financed the comprehensive assessment of the two largest banks and undertook a comprehensive Financial Sector Study in 2002. The Financial Sector Technical Assistance project supports the restructuring and reengineering of the Central Bank, introduction of professional management teams into the two large ailing commercial banks (the first step toward eventual restructuring of those banks), capacity building towards enhanced credit information, improved public awareness of financial sector issues and upgrading of staff training in financial institutions. The Financial Sector Restructuring project—for which Bank financing was approved in FY04—supports further strengthening of the Central Bank and deepening the reform process within the two large ailing commercial banks. In FY05, a Legal Financial Review was completed providing a snapshot of the legal and judicial environment for financial sector growth and development.

\section{Areas in which the IMF leads and its analysis serves as input into the Bank program}

The IMF leads the policy dialogue on maintaining sound macroeconomic policies as is the case with most Bank/IMF member countries. The PRGF-supported program serves as the macroeconomic policy anchor for ensuring successful implementation of the IAP/PRS and the Bank's program of support.

The IMF leads in encouraging reforms that are critical to the maintenance of macroeconomic stability, primarily on fiscal matters, such as maintaining sustainable domestic borrowing while allocating resources to priority sectors. Also, the IMF is taking the lead on the revenue side by setting realistic targets for increasing domestic revenues and advising on tax policy and administration.

\section{Areas in which the IMF leads and there is no direct Bank involvement}

The areas in which the IMF leads and the Bank is not directly involved are monetary policy, the exchange rate regime, the balance of payments and related statistical and measurement issues.

\section{World Bank Group Strategy and Lending Operations}

The Country Assistance Strategy (CAS). In November 2003, the Board considered a new Country Assistance Strategy (CAS), which discussed the rationale for implementing the Base 
Case lending program. Indeed, given the nature of the country's ongoing reforms, the 2002 CAS Progress Report (CAS PR) had already presented the justification for moving to a Base Case scenario and developing a programmatic approach to financial assistance. However, as mentioned previously, the assistance strategy is currently under review and could be substantially revised in light of the limited reform efforts over the past year.

The Base Case Lending Program. In FY04, credit approvals included PRSC I, Financial Sector Restructuring Project, Second Rural Water Supply and Sanitation and Poverty Alleviation Fund. In FY05, IDA financing was approved for the Education for All Project, the Health Sector Program, the Rural Access Improvement and Decentralization Project, and the Economic Reform Technical Assistance Project.

Bank Assistance Program in Nepal. As of December 28, 2005, IDA's lending portfolio consisted of twelve projects with a total commitment of US\$425 million and a total undisbursed balance of US\$296 million (Table 1).

Table 1. World Bank Operations

As of December 28, 2005

\begin{tabular}{lccc}
\hline & IDA Amount & Undisbursed 1/ & Board Date \\
& (In millions of U.S. dollars, net of cancellations) \\
& & & 2000 \\
Road Maintenance and Development & 54.5 & 16.2 & 2002 \\
Telecommunications Sector Reform & 22.6 & 14.5 & 2003 \\
Financial Sector Technical Assistance & 16.0 & 8.2 & 2003 \\
Power Development & 75.6 & 77.6 & 2003 \\
Community School Support & 5.0 & 3.4 & 2004 \\
Financial Sector Restructuring (Phase II) & 75.5 & 27.5 & 2004 \\
Poverty Alleviation Fund & 15.0 & 11.4 & 2004 \\
Rural Water Supply and Sanitation II & 25.3 & 23.5 & 2005 \\
Education for All & 50.0 & 38.0 & 2005 \\
Health Sector Program & 50.0 & 44.4 & 2005 \\
Rural Access Improvement and Development & 32.0 & 28.0 & 2005 \\
Economic Reform Technical Assistance & 3.0 & 2.9 & \\
Total & & & 295.6 \\
\hline
\end{tabular}

$1 /$ Credit accounting is in SDRs. As these figures are in US\$, exchange rate fluctuations may result in undisbursed balances greater than the principal amounts.

Economic and Sector Work. The 2003 Country Assistance Strategy (Report No. 26509-NEP, 11/24/2003) was discussed by the Bank's Board in November 2003. Recently completed economic and sector work includes Nepal Development Policy Review: Restarting Growth and Poverty Reduction (June 2004), Citizens with(out) Rights: Nepal Gender and Social Exclusion Assessment (June 2005), Nepal Decentralized Organizations Study (March 2004), Urbanization and Service Delivery in the Context of Decentralization: A Review of the Issues for the Kathmandu Valley (December 2004), Legal Financial Review (February 2005), and North South Transport Corridor Options (August 2004). 
IFC's Activities in Nepal. As of end-July 2005, IFC-held portfolio in Nepal is US\$67.7 million in two power generation projects, one tourism project and one leasing company. IFC will continue to support export-oriented manufacturing, private investment in telecommunications and power generation and distribution, financial market development and the growth of small and medium enterprises (SMEs). Due to the still weak security situation and political uncertainties, currently there are few investment opportunities in Nepal large enough for direct financing, so the IFC does not expect to make many new investments during the CAS period. Instead, IFC will focus on technical assistance for SMEs through the regional multi-donor technical assistance facility for SME development- the South Asia Enterprise Development Facility (SEDF) — based in Dhaka. This facility—funded by IFC in partnership with Canada, Netherlands, Norway, United Kingdom, AsDB and the European Union (EU) will deliver technical assistance programs in Nepal to increase SMEs' access to financing and business development services, improve the business environment for SMEs and develop linkages with larger enterprises.

Questions may be referred to Ms. Dado (473-2545). 


\section{Nepal-Relations with the Asian Development Bank}

\section{Lending Program}

As of June 30, 2005, total commitments by the Asian Development Bank (AsDB) consisted of 109 loans amounting to $\$ 2.17$ billion covering projects in agriculture and natural resources, education, energy, finance, industry and trade, law, economic management and public policy, transport and communication, and water supply, sanitation and waste management. Undisbursed funds of $\$ 585$ million represent 86 percent of the total net loan amount as of June 30, 2005. For the period $2005-07,15$ projects amounting to $\$ 350.00$ million are tentatively programmed.

Loans by the Asian Development Bank, 1969-2005

(As of June 30, 2005)

\begin{tabular}{lrrrrrr}
\hline & $\begin{array}{r}1969-2000 \\
\text { Approved }\end{array}$ & $\begin{array}{r}2001 \\
\text { Lopproved }\end{array}$ & $\begin{array}{r}2002 \\
\text { Approved }\end{array}$ & $\begin{array}{r}2003 \\
\text { Approved }\end{array}$ & $\begin{array}{r}2004 \\
\text { Approved }\end{array}$ & $\begin{array}{r}2005 \\
\text { Approved }\end{array}$ \\
& \multicolumn{7}{c}{ (In millions of U.S. dollars) } \\
Agriculture and natural resources & 656.23 & 0 & 0 & 20 & 70 & 0 \\
Education & 61.1 & 19.6 & 30 & 0 & 20 & 0 \\
Energy & 364.4 & 0 & 0 & 0 & 0 & 0 \\
Finance & 7.3 & 0 & 0 & 0 & 0 & 0 \\
Industry and trade & 129.18 & 0 & 0 & 0 & 0 & 0 \\
Law, economic and public policy & & 30 & & 35 & 0 & 0 \\
Transport and communication & 236.86 & 46 & 0 & 0 & 20 & 0 \\
Water supply, sanitation and waste & & & & & \\
management & 224 & 0 & 0 & 39 & 0 & 0 \\
Multisector & 127.06 & 0 & 30 & 0 & 0 & 0 \\
Total approved & $1,806.13$ & 95.60 & 60.00 & 94.00 & 110.00 & 0.00 \\
Gross disbursements & 1220.6 & 57.3 & 28.2 & 33.5 & 22.0 & 13.4 \\
Technical assistance projects & & & & & & \\
Total approved & 96.6 & 4.0 & 3.9 & 4.06 & 3.18 & 0 \\
Gross disbursements & 54.1 & 5.0 & 3.9 & 4.17 & 4.2 & 2.1 \\
\hline
\end{tabular}

Source: Data provided by the Asian Development Bank.

\section{Technical Assistance}

Since 1968, AsDB has provided Nepal with technical assistance in most sectors. As of June 30, 2005, total technical assistance consisted of 244 projects totaling $\$ 111.8$ million, of which 92 valued at $\$ 33.3$ million were for preparation of loan projects.

\section{Private Sector Operations}

As of June 30, 2005, AsDB has provided five private-sector loans in Nepal: two in industry, two in hydropower and one in tourism. Direct investment has involved \$49.5 million in loans and $\$ 3.3$ million in equity for a total of $\$ 52.8$ million. The AsDB's public sector lending and technical assistance program have also been helping Nepal to create a more conducive policy and legal environment for private sector development. 


\section{Nepal—Statistical Issues}

While the economic and financial database is adequate for program monitoring purposes, the lack of consistent and timely data hampers analysis and policy formulation and implementation. A multisector statistics mission (January 2001) prepared recommendations and an action plan to upgrade Nepal's statistics to international standards. Nepal provides core data to the Fund and releases data in government and central bank publications. Nepal has been a participant in the General Data Dissemination System (GDDS) since May 2001. Its metadata were initially posted on the Dissemination Standards Bulletin Board in May 2001 and last updated in August 2005.

\section{Real Sector}

The Central Bureau of Statistics (CBS) compiles national accounts statistics using the 1968 SNA. These statistics include GDP by industry (current and constant prices) and by expenditure categories (current prices), and gross national income and savings. The statistics are deficient due to lack of comprehensive and regular data sources. The limited source data suffer from inconsistencies, lags in availability, and insufficient detail. There are shortcomings in record keeping by agencies and access to records is not timely due to processing lags. Reflecting source data problems, compilation methods rely heavily on fixed ratios derived from surveys or ad hoc assumptions.

The consumer price index (CPI) was revised following completion of the 1995/96 household expenditure survey. The weights used for calculation of the CPI were updated and the revised series were published in May 2000. However, the revised CPI covers only urban areas and the consumption basket refers only to a subset of the population. The wholesale price index (WPI) was developed by the NRB and first published in July 2001. The weights for the WPI, based on 1999/2000 data, were derived using a commodity flow approach and the prices related to the first commercial transaction point. However, the compilation method needs to be improved to implement weekly or bi-weekly price collection; the number of price quotations need to be increased; and procedures for adjusting for quality differences should be implemented. The CBS, with STA assistance, is developing a monthly producer price index (PPI) series, to replace the manufacturing price index, which is based on unit values rather than actual transaction prices. The new price index is expected to provide better deflation of national accounts data and a more accurate measure of industrial sector inflation. The third STA mission to provide technical assistance on the development of the PPI took place in April-May 2004.

\section{Fiscal Sector}

A revised budget classification system, introduced in 1996/97 and since refined, has substantially improved fiscal statistics, in particular the division between current and capital spending. However, fiscal data by functional and economic classification is only provided on an irregular basis with varying degrees of coverage. In addition, large amounts are still allocated to the contingency account, and monthly reporting of development spending 
excludes amounts directly paid by donors. Moreover, a number of fees collected outside the budget and the operations of local governments are not reported in the annual budget.

More timely data on revenue and expenditure are needed for effective fiscal control. A financial management project is under way and a system of 'flash' reporting covering selected districts that account for the bulk of expenditure is being developed. Further improvement of fiscal data collected by the Financial Comptroller General's Office would permit the MoF to monitor more effectively actual revenue collections and expenditures, and to provide assessments during the course of the fiscal year. Such improvements will require further computerization in the MoF regional offices, donor financing, and additional TA.

Consolidated accounts for the public enterprise sector are not compiled on a regular basis, and financial reporting by many individual enterprises is subject to long delays. Fund staff has assisted the authorities in processing surveys of public enterprises. However, further assistance may be needed in survey design and processing.

The Nepal Rastra Bank (NRB) reports data regularly for publication in the Government Finance Statistics Yearbook.

\section{Monetary Sector}

Monetary data provided by the NRB have been subject to revisions with a substantial lag (up to 12 months), making program monitoring difficult. Money and banking statistics missions visited Nepal during April/May 1999 and March 2000 to assist in improving timeliness, compilation procedures, and the coverage of the financial system. The 2001 multisector mission recommended implementation of the residency criterion, instead of the currency basis, to distinguish foreign and domestic accounts. The mission also encouraged the NRB to improve procedures for grossing up balance sheet data to account for late reporting by commercial bank branches, which had led to the underestimation of broad money. In August 2002, the NRB informed STA about the introduction of new reporting forms for commercial banks, the implementation of which initially resulted in delayed transmissions of aggregated data on banks to STA. Beginning May 2003, STA received revised data on commercial banks for the period August 2001 through April 2003. Nepal's country page in the September 2005 edition of IFS shows data for the monetary authorities, deposit money banks, and interest rates through June 2005. However, some components of data on deposit money banks are still not reported, which prevents reporting in IFS key aggregates like claims on private sector and demand deposit liabilities.

The July 2003 monetary and financial statistics mission noted that the NRB has implemented some important guidelines of the IMF's Monetary and Financial Statistics Manual, notably on the sectorization of the economy and categorization of financial assets and liabilities. The mission identified a number of outstanding deficiencies in monetary statistics and made high priority recommendations to overcome the following important shortcomings: (1) inadequate staff and computer resources; (2) interdepartmental data discrepancies on foreign reserve data; (3) late reporting of commercial banks and other banking institutions; (4) inaccurate 
estimation for late reporting commercial bank branches; (5) large interbank discrepancies; and (6) incorrect recording of repurchase agreements. The mission also recommended that the authorities should consider the establishment of a Statistics Department in the context of NRB's ongoing reorganization.

\section{Balance of Payments}

A peripatetic Statistical Adviser conducted the last of a series of four missions during April 2004. Despite improvements, the balance of payments accounts exhibited large net errors and omissions for 2003/04. Work is underway to improve the estimation of workers' remittances, and the data sources for private capital flows. Further work is needed to improve the recording of oil transactions, grants, foreign direct investment, short-term inflows, and other private capital flows. In September 2003, the authorities began publishing the balance of payments in the format recommended by Fund technical assistance, but some other recommendations have not yet been fully implemented. Staffing is being strengthened.

Exports and imports data compiled by the NRB, the Customs Department, and the Trade Promotion Center (overseas trade only) exhibit discrepancies. Export and import price indices are not compiled, and information on trade volumes is unavailable. The Customs Department is being strengthened, but NRB staff continue to estimate unrecorded trade.

Incomplete and conflicting data on government external grants and loans complicate estimating foreign financing. The NRB monitors cash disbursements and repayments, but most commodity aid and direct payment are excluded. MoF reporting is also incomplete and not timely. With technical assistance from the United Kingdom's DFID, a new database providing comprehensive data on disbursements, payments, and the stock of outstanding government debt has been developed and is currently being refined. However, reporting of direct external grants remains a problem. 


\section{Nepal-Table of Common Indicators Required for Surveillance}

As of December 22, 2005

\begin{tabular}{|c|c|c|c|c|c|}
\hline & $\begin{array}{c}\text { Date of } \\
\text { Latest } \\
\text { Observation }\end{array}$ & $\begin{array}{c}\text { Date } \\
\text { Received }\end{array}$ & $\begin{array}{c}\text { Frequency } \\
\text { of } \\
\text { Data }^{6}\end{array}$ & $\begin{array}{l}\text { Frequency } \\
\quad \text { of } \\
\text { Reporting }^{6}\end{array}$ & $\begin{array}{c}\text { Frequency } \\
\text { of } \\
\text { Publication } \\
6\end{array}$ \\
\hline Exchange rates & Dec. 2005 & Dec. 2005 & $\mathrm{D}$ & $\mathrm{W}$ & $\mathrm{D}$ \\
\hline $\begin{array}{l}\text { International reserve assets and reserve liabilities of the } \\
\text { Monetary Authorities } 1\end{array}$ & Nov. 2005 & Dec. 2005 & $\mathrm{~W}$ & $\mathrm{~W}$ & M \\
\hline Reserve/base money & Aug. 2005 & Oct. 2005 & M & M & M \\
\hline Broad money & Aug. 2005 & Oct. 2005 & M & M & M \\
\hline Central bank balance sheet & Aug. 2005 & Oct. 2005 & M & M & M \\
\hline Consolidated balance sheet of the banking system & Aug. 2005 & Oct. 2005 & M & M & M \\
\hline Interest rates ${ }^{2}$ & Nov. 2005 & Dec. 2005 & $\mathrm{~W}$ & $\mathrm{~W}$ & $\mathrm{~W}$ \\
\hline Consumer price index & Sep. 2005 & Nov. 2005 & M & M & M \\
\hline $\begin{array}{l}\text { Revenue, expenditure, balance and composition of } \\
\text { financing }{ }^{3} \text { - general government }{ }^{4}\end{array}$ & Nov. 2005 & Dec. 2005 & $\mathrm{~W}$ & $\mathrm{~W}$ & $\mathrm{~W}$ \\
\hline $\begin{array}{l}\text { Revenue, expenditure, balance and composition of } \\
\text { financing }{ }^{3} \text { - central government }\end{array}$ & Nov. 2005 & Dec. 2005 & $\mathrm{~W}$ & $\mathrm{~W}$ & $\mathrm{~W}$ \\
\hline $\begin{array}{l}\text { Stocks of central government and central government- } \\
\text { guaranteed debt }\end{array}$ & $2002 / 03$ & Jun. 2005 & A & A & A \\
\hline External current account balance & $2002 / 03$ & Jun. 2005 & $\mathrm{Q} / \mathrm{A}$ & $\mathrm{Q} / \mathrm{A}$ & A \\
\hline Exports and imports of goods and services & 2003/04 & Jan. 2005 & M & M & M \\
\hline GDP/GNP & 2003/04 & Jun. 2005 & A & A & A \\
\hline Gross external debt & $2003 / 04$ & Jun. 2005 & A & A & A \\
\hline
\end{tabular}

${ }^{1}$ Includes reserve assets pledged or otherwise encumbered as well as net derivative positions.

${ }^{2}$ Both market-based and officially-determined, including discount rates, money market rates, rates on treasury bills, notes and bonds.

${ }^{3}$ Foreign, domestic bank, and domestic nonbank financing.

${ }^{4}$ The general government consists of the central government (budgetary funds, extra budgetary funds, and social security funds) and state and local governments.

${ }^{5}$ Including currency and maturity composition.

${ }^{6}$ Daily (D), weekly (W), monthly (M), quarterly (Q), annually (A), irregular (I); and not available (NA) 


\section{INTERNATIONAL MONETARY FUND}

\section{Public Information Notice}

EXTERNAL

RELATIONS

DEPARTMENT

Public Information Notice (PIN) No. 06/12

International Monetary Fund

FOR IMMEDIATE RELEASE

$70019^{\text {th }}$ Street, NW

February 2, 2006

Washington, D. C. 20431 USA

\section{IMF Executive Board Concludes 2005 Article IV Consultation with Nepal}

On January 18, 2006, the Executive Board of the International Monetary Fund (IMF) concluded the 2005 Article IV consultation with Nepal. ${ }^{1}$

\section{Background}

Growth has been affected by the political turmoil and conflict, although inflation has remained moderate and international reserves are adequate. Real GDP growth averaged 2 percent during 2000/01-2004/05, compared to the 1990s when growth in agricultural productivity and a significant trade liberalization contributed to average real GDP growth of 5 percent. Inflation has remained in the low single digits, although it rose to 73/4 percent in mid-October 2005 (12-month basis) due to weak agricultural performance following erratic weather conditions, a VAT rate increase in January 2005, and partial pass-through of higher international oil prices by Nepal Oil Corporation.

The overall and domestically financed deficits remained limited in 2004/05. The VAT rate was raised in the revised budget from 10 percent to 13 percent in early-2005, and helped raise revenue by $3 / 4$ percentage point of GDP to 13 percent of GDP. Even so, revenue fell short of the revised budget target due to weaker than projected growth and imports, continued excise leakages and delayed excise duty refunds from India. Current spending was lower than the revised budget: the higher civil service wages and allowances, and security-related

\footnotetext{
${ }^{1}$ Under Article IV of the IMF's Articles of Agreement, the IMF holds bilateral discussions with members, usually every year. A staff team visits the country, collects economic and financial information, and discusses with officials the country's economic developments and policies. On return to headquarters, the staff prepares a report, which forms the basis for discussion by the Executive Board. At the conclusion of the discussion, the Managing Director, as Chairman of the Board, summarizes the views of Executive Directors, and this summary is transmitted to the country's authorities.
} 
expenditures were more than offset by lower spending on development and social sector projects, especially in the conflict-affected areas. The overall deficit was significantly lower than budgeted (1 percent of GDP compared to 21/2 percent of GDP). As a result, although external loans fell short of the budget, as assistance from the World Bank, Asian Development Bank, and donors dwindled, the domestically financed deficit was also lower than budgeted (at $1 / 2$ percent of GDP).

Monetary and exchange rate policies remained geared to supporting the exchange rate peg to the Indian rupee. Broad money growth slowed from 123/4 percent in 2003/04 to 8 percent in 2004/05 reflecting substantially lower Net Foreign Assets accumulation by the Nepal Rastra Bank (NRB). While budget financing from the banking system was limited, private sector credit grew by 131/4 percent, mainly in consumer lending. Balance sheet consolidation by the two largest banks undergoing restructuring limited the growth of loans for manufacturing and services sectors. With high remittances, liquidity was ample, T-bill rates remained low, and interest rates edged lower.

The current account and overall balance of payments remained in surplus. Despite disruptions related to the insurgency and the elimination of textile quotas, total exports rose by 10 percent in 2004/05. This was mainly due to booming exports to India which rose by 30 percent, while exports to other countries declined by over 15 percent. Export performance in traditional sectors-garments, carpets, and pashmina-remained weak. Total import growth was stagnant due to weak economic activity - a 35 percent increase in oil imports reflecting higher international prices was offset by a 6 percent decline in non-oil imports. Reflecting continued strong remittances, the current account surplus (excluding official transfers) increased from 1 percent of GDP in 2003/04 to 3 percent of GDP in 2004/05. A small overall surplus in the balance of payments led to an increase in international reserves to around US $\$ 1.5$ billion (73/4 months of imports of goods and services) at end-2004/05.

Financial soundness indicators have broadly improved in recent years due to banking reforms. External management teams at Nepal Bank Limited (NBL) and Rastriya Banijya Bank (RBB)the two largest banks which account for 50 percent of banking system deposits-have made notable progress over the past three years. They have turned the banks around from loss-making entities in 2000/01 by lowering cost of funds and eliminating excess staffing through voluntary retirement schemes. Both banks made profits in 2003/04 and 2004/05. Management and credit evaluation practices in the banks have also improved significantly. In addition, Asian Development Bank supported restructuring plans for Agricultural Development Bank of Nepal have proceeded well. In contrast, the financial condition of Nepal Industrial Development Corporation remains dismal.

The share of non-performing assets in NBL and RBB remains high. Improvements in the legal framework over the last two years and new debt recovery mechanisms (blacklisting directives, the Debt Recovery Tribunal, and an Appellate Tribunal) have helped recoveries from small and medium-sized defaulters. However, recoveries from large, willful and politically-connected defaulters remain limited. Recoveries from these defaulters are required to improve NBL and RBB balance sheets, reduce contingent liabilities for the budget, and pave the way for their 
privatization. The banks have been reluctant to pursue these cases in the Debt Recovery Tribunal due to concerns about its limited staff and capacity.

Nepal's growth prospects are contingent on political stability and improved security, and risks remain. Staff project real GDP growth of $2 \frac{1}{2}-3 \frac{1}{2} 2$ percent in $2005 / 06$. In this scenario, if political stability and better security conditions can be established and structural reforms are implemented, Nepal could see a gradual return to growth rates of 5-51/2 percent through 2009/10. This would require a rebound in manufacturing and service sectors, higher tourism earnings, and a larger contribution from agriculture and government activity. With the peg, inflation is expected to broadly follow price developments in India. The balance of payments surplus is projected to broadly decline. Export growth is projected to average 8 percent assuming Nepal can further diversify its exports beyond traditional sectors. Imports (both oil and non-oil) are projected to pick up with economic activity. Trade deficits could be covered by remittances and aid. International reserves are projected to remain around 6-7 months of imports of goods and services. If the conflict persists and the political impasse stalls reform implementation, low growth rates are likely to become entrenched, security-related spending pressures will remain high, and development spending low. In these conditions, the fiscal and external position could deteriorate, and international reserves could be lower. Key risks going forward include slow reform implementation which would jeopardize external assistance and higher global oil prices.

Nepal provided inaccurate information related to the second disbursement made in November 2004 under the Poverty Reduction and Growth Facility arrangement due to weaknesses in its debt recording system. As a result of this misreporting, the disbursement was noncomplying. The disbursement was made on the basis of a finding that all conditions applicable to the disbursement, including on the nonaccumulation of external payment arrears, had been met. This finding later proved incorrect, as Nepal had accumulated external payment arrears to Austria, including between November 2003 (when the arrangement was approved) and October 2004 (when the first review under the arrangement was completed). However, corrective actions have been taken. The arrears which led to the noncomplying disbursement have been cleared. The arrears are attributable to weak debt management and coordination problems, which the authorities are now addressing.

\section{Executive Board Assessment}

Executive Directors noted that Nepal is currently at a critical juncture, as political uncertainties and the ongoing insurgency continue to dampen economic growth. They encouraged the authorities to resolve these uncertainties, improve security, and make progress toward peace as essential steps to support poverty reduction efforts and private sector led growth.

Directors commended the authorities for maintaining macroeconomic stability under a difficult environment and for progress made in reform implementation until mid-2004. They encouraged the authorities to reinvigorate the implementation of policies in Nepal's Poverty Reduction Strategy Paper, which remains an appropriate framework to address key constraints on growth, maintain macroeconomic stability, and reduce poverty. This would also help mobilize external assistance by bringing the PRGF arrangement and donor programs back on track, as well as 
lay the basis for possible debt relief under the HIPC Initiative and the Multilateral Debt Relief Initiative.

On fiscal policies, Directors commended efforts to mobilize revenue, prioritize expenditure, increase social sector spending, and limit domestic budget financing. They encouraged further efforts to improve tax administration to raise collection levels. Directors expressed concern that security-related spending pressures remain high, and development spending is low relative to budget targets, especially in conflict-affected areas. They encouraged efforts to raise spending on infrastructure and social sector projects to achieve PRSP goals, while limiting domestically financed deficits to levels consistent with medium-term fiscal sustainability. Directors also favored early implementation of an automatic pricing mechanism for petroleum products in order to improve the financial condition of the Nepal Oil Corporation so that it does not pose an additional burden on the budget.

Directors emphasized the need to increase fiscal transparency, improve public expenditure management, and address donor concerns about the quality of spending. To this end, they suggested implementation of the fiscal ROSC recommendations, including broader coverage of off-budget activities. In this context, Directors called for more comprehensive reporting of security-related spending.

Directors agreed that the exchange rate peg to the Indian rupee remains appropriate. They noted that the peg enables the economy to benefit from close ties with India and helps to keep inflation at low levels. Directors considered that the level of the peg should be kept under review, given Nepal's growing integration in the world economy through its membership in the WTO and regional trading arrangements. External competitiveness should be raised through structural reforms and infrastructure investments to lower transactions and transportation costs.

Directors commended the progress made in financial sector reforms, while observing that much remains to be done. They welcomed the measures taken to improve the debt recovery framework, raise efficiency at the Nepal Rastra Bank, and to restructure commercial and development banks. Going forward, Directors noted that the legal framework for financial sector activity can be further improved through amendments to the Banking and Financial Institutions Ordinance. They encouraged the NRB to enhance financial sector supervision, and raise its internal audit and accounting standards. Directors emphasized that significant loan recoveries from large, willful defaulters are required to improve the balance sheets of ailing commercial banks. The delay in the restructuring of the Nepal Industrial Development Corporation should be addressed by privatizing it promptly and transparently. Given the important role played by remittances in strengthening the country's external position and reducing poverty, Directors encouraged the authorities to facilitate remittances through formal channels by reducing transaction costs and to help redirect remittances for investment and employment creation in Nepal. They called on the authorities to press forward with implementation of a strong antimoney laundering and combating the financing of terrorism regime.

Directors recommended an acceleration in the pace of public enterprise and governance reforms. They stressed that liquidation of unviable loss-making enterprises should proceed decisively, and encouraged mechanisms—such as share sales and management contracts- 
to improve the efficiency of large public enterprises. Directors welcomed adoption of the Civil Service Ordinance to improve governance, and urged early promulgation of the Governance Ordinance. They emphasized that anti-corruption efforts need to focus on large, prominent offenders to yield measurable results.

Directors encouraged creation of an enabling environment for private sector activity by upgrading the regulatory framework and making labor markets more flexible. They welcomed the promulgation of the Secured Transactions, Company, Securities, and Insolvency Ordinances. Directors urged early promulgation of the draft Labor Ordinance.

Given the importance of agriculture and the high level of rural poverty, Directors encouraged progress with implementing Agricultural Perspective Plan policies to raise agricultural productivity. This involves providing complementary inputs to land and improving rural infrastructure to promote commercialization and market access for agricultural products.

Directors regretted the misreporting of external payment arrears related to the second disbursement under the PRGF arrangement. They welcomed the clearance of these arrears and efforts to strengthen external debt management. With the corrective actions, Directors approved the request of a waiver for Nepal's nonobservance of the performance criterion on the nonaccumulation of external payment arrears.

Directors stressed the need to address data deficiencies to improve policy formulation and monitoring, and urged full implementation of Fund technical assistance recommendations.

Public Information Notices (PINs) form part of the IMF's efforts to promote transparency of the IMF's views and analysis of economic developments and policies. With the consent of the country (or countries) concerned, PINs are issued after Executive Board discussions of Article IV consultations with member countries, of its surveillance of developments at the regional level, of post-program monitoring, and of ex post assessments of member countries with longer-term program engagements. PINs are also issued after Executive Board discussions of general policy matters, unless otherwise decided by the Executive Board in a particular case. 
Nepal: Selected Economic Indicators, 2000/01-2004/05 1/

\begin{tabular}{|c|c|c|c|c|c|}
\hline & $2000 / 01$ & $2001 / 02$ & $2002 / 03$ & $2003 / 04$ & $\begin{array}{r}2004 / 05 \\
\text { Est. }\end{array}$ \\
\hline & \multicolumn{5}{|c|}{ (Percent change) } \\
\hline \multicolumn{6}{|l|}{ Output and prices } \\
\hline Change in real GDP & 5.6 & -0.6 & 3.4 & 3.4 & 2.5 \\
\hline Change in CPI (end-period) & 3.4 & 3.5 & 6.1 & 2.0 & 6.6 \\
\hline & \multicolumn{5}{|c|}{ (Percent of GDP) } \\
\hline \multicolumn{6}{|l|}{ Budgetary operations } \\
\hline Total revenue & 11.4 & 11.5 & 12.3 & 12.2 & 13.0 \\
\hline Total expenditure & 17.5 & 17.2 & 16.0 & 15.5 & 16.0 \\
\hline Current expenditure & 11.1 & 11.5 & 11.4 & 11.2 & 11.7 \\
\hline Capital expenditure and net lending & 6.4 & 5.6 & 4.6 & 4.3 & 4.3 \\
\hline Overall deficit 2/ & 4.5 & 4.3 & 1.6 & 1.0 & 0.9 \\
\hline & \multicolumn{5}{|c|}{ (Percent of GDP) } \\
\hline \multicolumn{6}{|l|}{ Money and credit } \\
\hline Broad money & 15.2 & 4.4 & 9.8 & 12.7 & 8.0 \\
\hline Domestic credit & 18.8 & 9.2 & 12.0 & 9.3 & 13.3 \\
\hline & \multicolumn{5}{|c|}{ (In millions of U.S. dollars, unless otherwise indicated) } \\
\hline \multicolumn{6}{|l|}{ External sector } \\
\hline Exports , f.o.b. $3 /$ & 945 & 754 & 653 & 748 & 826 \\
\hline Imports, f.o.b. & 1,710 & 1,448 & 1,556 & 1,801 & 1,806 \\
\hline Current account $4 /$ & 162 & 106 & 16 & 59 & 226 \\
\hline (In percent of GDP) 4/ & 2.9 & 1.9 & 0.3 & 0.9 & 3.1 \\
\hline Overall balance & 38 & -39 & 93 & 235 & 24 \\
\hline Gross official reserves & 1,020 & 1,048 & 1,178 & 1,471 & 1,507 \\
\hline Rupees per U.S. dollar (end-period) & 74.7 & 78.0 & 74.8 & 74.1 & 70.0 \\
\hline
\end{tabular}

Sources: Nepalese authorities; and IMF staff estimates.

1/ Fiscal year begins mid July.

2/ After grants.

3/ Includes re-exports.

4/ Excluding grants. 


\section{Statement by Hooi Eng Phang, Executive Director for Nepal January 18, 2006}

1. The Nepalese authorities sincerely appreciate the efforts made by the IMF staff in conducting the Article IV Consultation in October-November 2005 and for preparing the report on macroeconomic developments and policy challenges facing the Nepalese economy. The authorities have found the report comprehensive, analytical and, at times critical on matters relating to the pace of policy implementation. The authorities gratefully acknowledge the policy advice and would also like to assure the staff, the management and the Executive Board that policy measures recommended for institution building, structural reforms and maintaining macroeconomic stability will be earnestly implemented to facilitate growth and alleviate poverty.

\section{The Current Challenge}

2. Currently, Nepal is at a critical juncture. A decade long insurgency has taken a heavy toll in terms of loss of human lives, disruption of social life and retardation of economic growth. After the mid 1990s, frequent changes in the government have created political instability. Consequently, local elections and general elections could not take place as scheduled and local bodies and the parliament have remained without any representation.

3. Against this background of emerging constitutional crisis, His Majesty the King took the step on February 1, 2004 to form a new government. The new government has taken initiatives to hold both local and parliamentary elections which have been scheduled for February 2006 and April 2007, respectively. Considering the importance of the election process, His Majesty's Government of Nepal is committed towards the successful completion of these elections, which will help the country to return to normalcy and resolve the social and political tensions confronting the Nepalese society today.

\section{Macroeconomic Developments}

4. The Nepalese economy, which had registered a good performance during the early 1990 s, is experiencing a setback and registering modest growth in recent years. The decade long insurgency induced social tensions and political instability which have caused growth to fall significantly below trend. Real GDP growth decelerated to 2.5 percent in 2004/05 from 3.4 percent in 2003/04. A decline in agricultural production owing to unfavorable weather conditions, negative growth of the construction and trade, hotel and restaurant sub-sectors and slow down in the growth rate of some other non- agricultural sub-sectors dampened the growth momentum. While growth in agriculture decelerated to 2.8 percent in 2004/05 from 3.9 percent in 2003/04, non-agriculture GDP growth rate declined to 1.6 percent in 2004/05 from 2.9 percent in 2003/04. Risks to growth still persist. Weather conditions this year have 
also remained less than favorable. Against this background, economic growth is expected to remain modest in 2005/06.

5. Despite the low rate of economic growth, insurgency and political instability, inflation remained low and controlled in recent years. The CPI-based average annual rate of inflation remained low at 4.5 percent in 2004/05, albeit a pick up from 4.0 percent in 2003/04. Nonetheless, inflation remained broadly in line with the South Asian regional average. Restrained monetary expansion, prudent fiscal policy and the pegged exchange rate arrangement with the Indian currency have contributed to maintain the rate of inflation below the 5 percent level. However, a build-up in inflationary pressure is expected in 2005/06. A pick-up in global inflation, an increase in the VAT rate from 10 percent to 13 percent in January 2005, and the adjustment in fuel prices by Nepal Oil Corporation (NOC) in January and September 2005 have contributed to the recent surge in inflation. However, with the peg, inflation in Nepal is expected to align with the trend in the region. Should any deviation occur, the magnitude of deviation from the regional level of inflation will not exceed 2-3 percentage points in 2005/06.

6. The overall external sector remained stable despite the shock emanating from the elimination of the textile quota and the negative impact of insurgency on tourism. Both the current account and overall balance of payments remained in surplus. Total exports rose by 10.6 percent in 2004/05 mainly due to the significant growth of 33.3 percent in exports to India. Total imports fell by 0.7 percent, reflecting stagnation in economic activities.

7. Formal inflows of remittances is the single largest source of foreign exchange accounting for approximately 12 percent of GDP. Remittances, the mainstay of the Nepalese economy, have contributed to sustaining macroeconomic stability. In the face of a significant fall in foreign aid, travel receipts and exports, persistent rising inflows of workers' remittances contributed to the current account and overall balance of payments surplus. A significant increase in remittances has also contributed to the accumulation of international reserves, sufficient to meet the country's international obligation and to cover 7.5 months' of imports of goods and services.

8. Remittances have exerted positive microeconomic impact especially in poverty alleviation. This is evident from the result of the second Nepal Living Standards Survey, which showed a reduction in absolute poverty level from 42 percent in 1995/96 to 31 percent in $2003 / 04$.

9. Despite the situation of unease, the budget deficit has been kept in check. Nepal's fiscal deficit stands lower than the South Asian average. This also contributed to maintain macroeconomic stability in the country. The fiscal deficit, on a cash flow basis, remained more or less at the preceding year's level of 2.6 percent of GDP in 2004/05. Net domestic borrowing also remained below 1 percent ( 0.9 percent $)$ of GDP in 2004/05. Domestic revenue collection rose to 13.3 percent of GDP in 2004/05, up from 12.6 percent in 2003/04. 
10. The growth of broad money decelerated to 8.3 percent in $2004 / 05$ from 12.8 percent in 2003/04. Lower NFA accumulation together with containment of domestic credit slowed the growth of broad money.

\section{Developments in Policy Reform}

11. The Nepalese authorities agree with the staff that, among others, the key economic policy challenges facing Nepal are maintaining macroeconomic stability, restoring growth and reducing poverty. The authorities are in broad agreement with the staff that while prudent monetary, foreign exchange and fiscal policies are crucial to maintain macroeconomic stability, structural reforms in financial and public sectors are key to restoring growth and reducing poverty. The authorities are committed to using the basic guidelines of the PRSP for spearheading policy reforms.

12. Macroeconomic policies have remained prudent and stable despite the difficult situation prevailing in the country. The Nepalese authorities gratefully acknowledge the contribution of donor agencies in terms of their advice in formulating and implementing macroeconomic policies in a prudent manner under the framework of the PRSP funded by the World Bank, PRGF supported by the IMF and governance reform program and public sector management aided by AsDB.

13. The Nepalese authorities concur with the staff's observation that monetary and exchange rate policies should remain geared to supporting the current exchange rate peg. The peg has served Nepal well in keeping inflation low and maintaining macroeconomic stability. However, the authorities are mindful that the level of the peg needs to be continuously reviewed to take account of its trade competitiveness vis-à-vis other SAARC countries.

14. With the enactment of NRB Act 2002, Nepal Rastra Bank (NRB) has started the practice of announcing annual monetary policy at the beginning of the fiscal year. The mid-term review of monetary policy is also made public. These practices have streamlined and made the conduct of monetary policy transparent and accountable. These practices have also made the communication channels of monetary policy accessible and open to diverse stakeholders. On July 22, 2005, NRB issued the annual monetary policy for 2005/06. In the face of emerging pressure on prices, NRB signaled a tight monetary policy stance by increasing the bank rate from 5.5 percent to 6.0 percent. The monetary policy implementation strategy has also been revamped. The excess reserves of commercial banks, the counter-parties in the conduct of monetary policy, has been chosen as the operating target of monetary policy. Open market operations in the form of sale auction, purchase auction, repo auction and reverse repo auction have been selected as short term instruments in the conduct of monetary policy. The liquidity monitoring and forecasting framework (LMFF) has been put in place to guide the monetary operations.

15. The authorities are vigilant on the likely impact of rising remittances on inflation. In order to keep money supply, and thereby inflation in check, remittance induced foreign 
inflows are sterilized through open market operations. Inflation is broadly in check. The real effective exchange rate has also remained relatively stable.

16. Fiscal policy has also been geared to maintain stable macroeconomic conditions in support of private sector led economic growth. The objectives of annual budgets formulated under the medium term expenditure framework (MTEF) are to improve revenue mobilization, contain expenditure pressure and limit domestic borrowing. To meet the shortfall in foreign assistance and thereby to avoid macroeconomic imbalance arising from resource shortfall, the authorities increased the VAT rate in January 2005. Performance-based incentive schemes in the Large Taxpayer Office (LTO) are being planned. The authorities have succeeded in containing government expenditure so as to contain domestic borrowing within prudential limits and to maintain the fiscal deficit at a sustainable level.

17. With regard to the non-observance of the performance criterion on external payment arrears to bilateral donors at the completion of the first review of Nepal's PRGF program in October 2004, the Nepalese authorities would like to assure the Executive Board that the incidents were unintentional and the result of weak debt data management in Nepal, including coordination problems among domestic agencies. As acknowledged by the staff, the Nepalese authorities are making good faith efforts to service their debt in a timely manner and steps have been taken not only to repay undisputed arrears but also to improve external debt data management to ensure accurate monitoring of external debt obligations and to avoid a recurrence of the problem. In light of these corrective actions taken, the Nepalese authorities request that the Executive Board grant a waiver for Nepal's non-observance of the continuous performance criteria on non-accumulation of external payment arrears.

18. The authorities are in agreement with the staff that the key structural reform areas are the financial sector, public enterprises and governance, and the successful implementation of structural reforms is crucial for accelerating growth.

19. On the financial sector reforms, the focus is on increasing the loan recovery from large willful defaulters, improving financial sector legislation, strengthening the central bank and restructuring insolvent commercial banks and development banks. Nevertheless, it remains a challenge to recover loans from large defaulters. The tenure of foreign management teams in large problem banks has been extended. As part of the overall effort to improve the regulatory framework, the authorities have recently issued the Secured Transactions, Company, Securities and Insolvency Ordinances.

20. Voluntary and compulsory retirement schemes were introduced recently in line with the strategy to re-engineer Nepal Rastra Bank(NRB). The bank has been successfully downsized. Further efforts are underway to enhance the capacity of existing staff.

21. The authorities acknowledge that the reform of public enterprises has been rather slow. Very recently, Lumbini Sugar Factory has been privatized. In line with the governance reforms, the Civil Service Ordinance was promulgated in July 2005. The authorities are 
also in the process of promulgating the Governance Ordinance aimed at clarifying responsibilities between the executive and the civil service.

\section{Technical Assistance}

22. The authorities would like to thank the IMF for the provision of a variety of technical assistance. NRB has received technical assistance in strengthening money and banking statistics and reforming the monetary policy implementation strategy and foreign exchange management. NRB has also been the recipient of technical assistance from the IMF on safeguard issues. On the advice of the IMF, NRB has appointed international auditors for the last three years. Technical assistance received from the IMF for the improvement of internal audit and financial management departments has been very beneficial. NRB has benefited in terms of capacity building and the adoption of international best practices in internal audit and financial management.

\section{Conclusion}

23. A decade long insurgency continues to haunt Nepal. The insurgency has slowed the process of economic growth and impeded poverty reduction efforts. Maintaining macroeconomic stability, introducing structural and policy reforms, accelerating economic growth and reducing poverty are the current challenges facing Nepal. To overcome these challenges, domestic effort alone is not sufficient. Nepal has benefited from both financial and technical support from the international community in mitigating the severity of these challenges in the past. Nepal looks forward to the continued support of the international community in its endeavor to overcome these challenges in the future.

24. We are pleased to inform the Board that the Nepalese authorities consent to the publication of the staff report and the accompanying documents, with necessary deletions of market sensitive information. 